\title{
Emergent Complexity, Changing Landscapes, and Spheres of Interaction in Southeastern South America During the Middle and Late Holocene
}

\author{
José Iriarte $^{1} \cdot$ Paulo DeBlasis $^{2} \cdot$ Jonas Gregorio De Souza ${ }^{1}$. \\ Rafael Corteletti ${ }^{2}$
}

Published online: 30 December 2016

(C) The Author(s) 2016. This article is published with open access at Springerlink.com

\begin{abstract}
Newly created academic programs at Brazilian universities have provided the impetus for new archaeological projects in southeastern South America during the last two decades. The new data are changing our views on emergent social complexity, natural and human-induced transformation of the landscape, and transcontinental expansions and cultural interactions across the Río de la Plata basin during the Middle and Late Holocene. We concentrate on six major archaeological traditions/regions: the Sambaquis, the Pantanal, the Constructores de Cerritos, the Tupiguarani, the Southern Proto-Jê, and the middle and lower Paraná River. Diverse and autonomous complex developments exhibit distinct built landscapes in a region previously thought of as marginal compared with cultural developments in the Andes or Mesoamerica. The trajectories toward increased sociopolitical complexity flourished in very different and changing environmental conditions. While some groups were pushed to wetland areas during a drier mid-Holocene, others took advantage of the more humid Late Holocene climate to intensively manage Araucaria forests. The start of the second millennium AD was a critical period marked by an increased number of archaeological sites, the construction of ceremonial architecture, and the intensification of landscape transformation; it also was marked by the rapid expansion of influences from outside the La Plata basin. The Amazonian Tupiguarani and Arawak newcomers brought with them significant changes in technologies and social and political structures, as well as novel landscape management practices.
\end{abstract}

José Iriarte

J.Iriarte@exeter.ac.uk

1 Department of Archaeology, College of Humanities, University of Exeter, Laver Building, North Park Road, Exeter EX4 4QE, UK

2 Museu de Arqueologia e Etnologia, Universidade de São Paulo (MAE-USP), Av. Prof. Almeida Prado 1466, São Paulo 05508-900, Brazil 
Keywords South America · Río de la Plata · Early Formative · Emergent complexity $\cdot$ Landscapes $\cdot$ Community patterns $\cdot$ Zea mays

\section{Introduction}

Large river systems in the Americas were major avenues that promoted the emergence of complex societies and multiethnic cultural interactions over vast regions during the Middle and Late Holocene (e.g., Gassón 2002; Heckenberger and Neves 2009; Iriarte et al. 2004; Roosevelt 1999; Saunders et al. 1997; Schaan 2012). Southeastern South America encompasses the eastern sector of the Río de la Plata basin - the second largest river system in the Americas - and its adjacent Atlantic Coast. With several major zones of ecological and cultural diversity, this region constitutes a geographical enclave where cultural traditions converged and interacted, giving rise to a diversity of social developments during pre-Columbian times (Dillehay 1993; Iriarte et al. 2008a; Noelli 1999/2000; Politis and Bonomo 2012; Rodríguez 1992; Rogge 2005).

Long viewed as a marginal area compared to the Andes and the CircumCaribbean (Meggers and Evans 1978; Steward and Faron 1959), we are learning that this region had an early sequence of cultural trajectories contemporaneous with the first urban societies in the Andes and the rise of the Amazonian Formative (e.g., Burger 1995; Dillehay 2014; Heckenberger and Neves 2009). During the last two decades, the archaeology of this region has received new energy through the development of several archaeological projects at national universities in Brazil (e.g., López Mazz 1999) and the arrival of land development-funded archaeology (e.g., Copé 2007; DeMasi 2006). A large portion of the original work reported in this article appears in unpublished theses, completed mainly in Brazilian universities. This renewed archaeological research, combined with new conceptual and methodological advances, allows us to discuss in detail issues relating to the emergence of social complexity, the scale and nature of past human impact on these landscapes, and the role of regional interaction networks in a way that was not possible before.

We begin with an overview of recent developments in the Middle and Late Holocene archaeology of the region, followed by a discussion of how these new data are changing our views on the emergence of social complexity, the transformation of landscapes, migrations, and the establishment of interaction spheres during the Late Holocene. The introductory sections present the diverse environments and a summary of the Middle and Late Holocene archaeological cultures of the region (Fig. 1). In the following thematic sections, we present key findings and emerging research agendas for each archaeological culture. Finally, we summarize the major new findings and briefly discuss the main thematic concerns in the context of South America. We focus on major trends without intending to provide a complete overview of all recent excavations or interpretations. Not included in our review are the archaeology of Paraguay and large parts of the Gran Chaco and the archaeology of mid-Holocene hunter-gatherers. Similarly, we highlight major historical trends in 


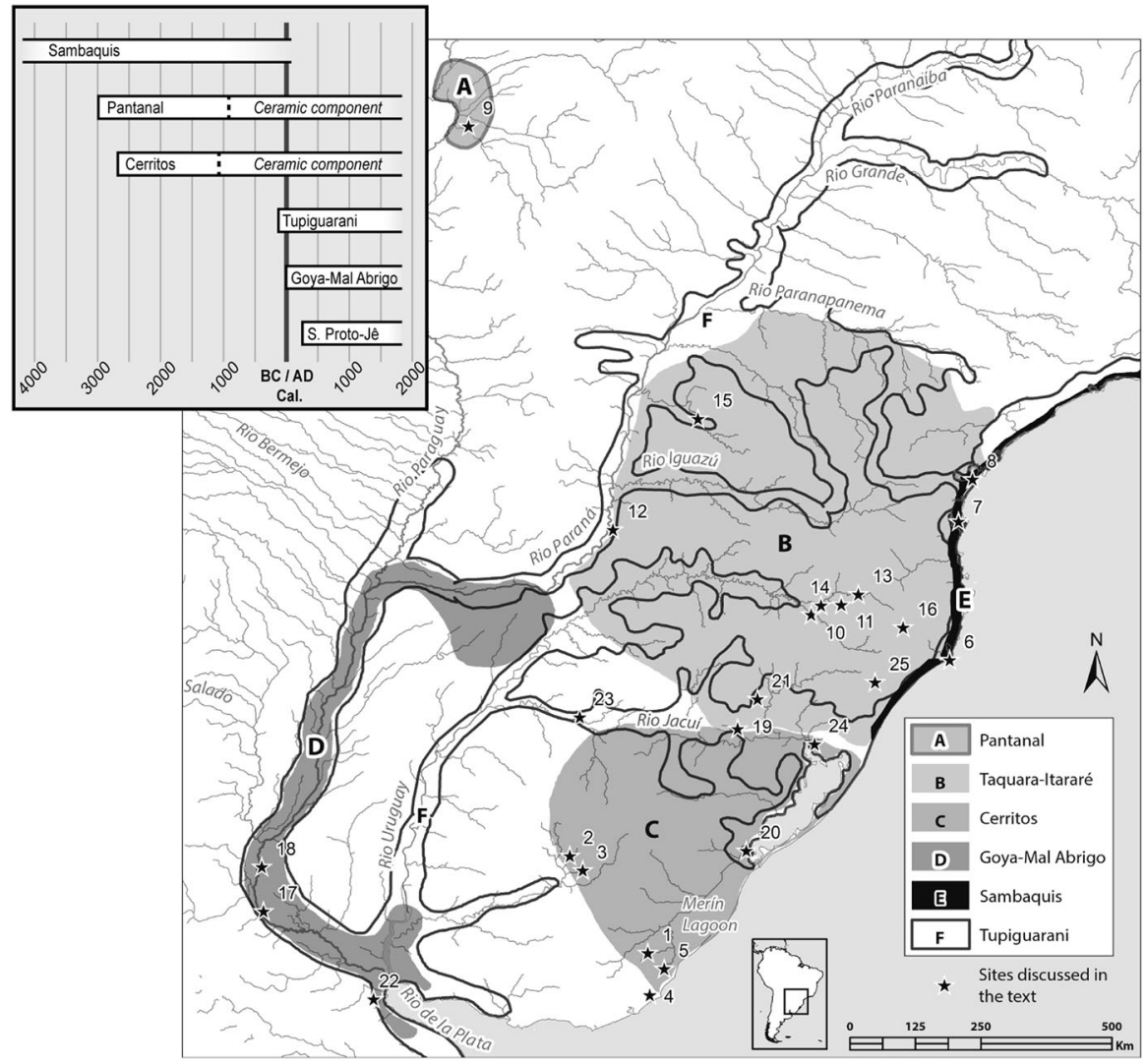

Fig. 1 Map (right) showing approximate locations of major archaeological traditions and archaeological sites in southeastern South America during the Middle and Late Holocene that are discussed in the text. Cerritos: 1, India Muerta region (Los Ajos, Estancia Mal Abrigo, Puntas de San Luis); 2, Lemos; 3 , Pago Lindo; 4, Laguna de Castillos; 5, Laguna Negra (Los Indios, CH2D01, CH1D01). Sambaquis: 6, Santa Marta Lagoon and Cape (Caieiras, Congonhas, Jabuticabeira, Carniça, Mato Alto, Morrote); 7, Babitonga Bay; 8, Guaratuba and Paranaguá Bays. Pantanal: 9, MS-MA-50 site. Southern Proto-Jê: 10, Pinhal da Serra and Anita Garibaldi regions (Avelino, Chico Carneiro, Leopoldo, Ari, Posto Fiscal, Reco, SC-AG98, SC-AG-108); 11, Campo Belo and San José do Cerrito regions (Abreu and Garcia, SC-CL-52, Rincão dos Albinos); 12, PM01; 13, SC-CL-37; 14, SC-AG-12; 15, PR-UB-04; 16, Urubici region (Avencal, Bonin). Goya-Malabrigo: 17, Tres Cerros; 18, Tapera Vázquez. Tupiguarani: 19, Pardo River valley; 20, Pelotas region; 21, RS-T-114. Paraná Delta region: 22, Arroyo Fredes, La Bellaca, Las Vizcacheras. Pollen sites: 23, São Francisco de Assis; 24, Morro Santana; 25, Cambará do Sul. Schematic chronological chart (left) of major archaeological traditions in southeastern South America

each particular section but do not produce a detailed account of the history of archaeological investigations in each region (see López Mazz 1999; Noelli 2005; Politis 2003). 


\section{The Environmental Diversity of the La Plata Basin and Its Adjacent Littoral Zone}

The La Plata basin drains about one-quarter of the South American continent. It encompasses parts of Argentina, Bolivia, Brazil, Paraguay, and Uruguay, covering $3,100,000 \mathrm{~km}^{2}$. Like the Amazon River system, it comprises a network of huge rivers that constituted a major avenue for communication among different preColumbian groups. There are no important geographical barriers that separate these two large river systems. South of the Amazon, the annual inundation of the Llanos de Mojos and the Gran Chaco merge the basins of the Río Madeira and the Río Paraguay, respectively, into a vast "freshwater sea," opening up a network of waterways that extend south to the Río de la Plata estuary (e.g., Lathrap 1970; Lothrop 1931; Torres 1911). The movement of people was certainly facilitated by the lack of geographical barriers and the connectedness of the Amazon-La Plata basins. Most of the tropical, subtropical, and parts of temperate areas of South America were connected by waterways that were easily traveled by groups who possessed watercraft, such as the Tupiguarani and Arawak. The ease of water travel has implication for the migration and expansion of people.

The Río de la Plata basin and adjacent Atlantic Coast encompass an enormous ecological diversity characterized by a mosaic of environments that shaped, and were shaped by, different types of pre-Columbian land use. The Atlantic coastal plain to the east, with its rich estuaries, lagoons, and mangroves, is covered by restinga vegetation (sandy soil grasslands, shrubs, and forests). The southern Brazilian highlands constitute a plateau above the Atlantic Coast, from nearly $1900 \mathrm{~m}$ above sea level in the easternmost peaks of Serra do Mar and sloping west to the Río de la Plata basin. Subtropical mixed Araucaria forest and high-altitude grasslands cover the plateau. Its eastern escarpment is dominated by the Atlantic Forest_-one of the last remaining biodiversity hotspots on earth (Myers et al. 2000); subtropical semideciduous Interior Atlantic Forest covers the western and southern escarpment. West and south of the plateau are large expanses of savannah and grasslands intersected by gallery forest, xerophytic forest, palm groves, and vast areas of wetlands including the Pantanal, the world's largest tropical wetland $\left(140,000 \mathrm{~km}^{2}\right)$ (Clapperton 1993). To the south, large floodplains continue virtually uninterrupted, spreading through the humid Chaco region of Paraguay and Argentina. Hundreds of miles from the Río de la Plata, the Paraná deposits silt to form the innumerable and intermittent islands of the Paraná Delta, characterized by subtropical wetlands, riverine islands and grasslands, and xerophilous and subtropical semideciduous forest.

Paleoecological studies show that the region experienced major changes in climate, vegetation, fire regimes, and sea levels during the Middle and Late Holocene, which created constraints and opportunities for pre-Columbian populations (e.g., DeBlasis et al. 2007; Iriarte 2006b). While the mid-Holocene drought seems to have promoted increased sedentism in the form of mounded villages around the wetlands of southwest Uruguay, the more humid climate of the Late Holocene is likely to have encouraged the spread of forest and facilitated the 
expansion of Araucaria forests in the southern Brazilian highlands. Some groups were fairly restricted to certain environmental zones, such as the Constructores de Cerritos (hereafter called Cerritos) in wetlands, the Sambaquis in the coastal bays, and the Tupiguarani who mostly expanded to forested floodplains. Other groups, like the Southern Proto-Jê, thrived in a diversity of environments including the Atlantic coastal plain, the Atlantic Forest escarpment, and the southern Brazilian plateau.

\section{Overview of Middle and Late Holocene Archaeology in the La Plata Basin}

\section{The Middle Holocene}

Renewed archaeological work in the region reveals the appearance of social complexity during the mid-Holocene, as exemplified by the Cerritos, the Sambaquis, and potentially the preceramic Pantanal. These developments, contemporary with early urban societies in Peru and the Amazonian Formative, indicate that the region was a major center of cultural development.

\section{Sambaquis}

Shell mounds (or sambaquis) on the Brazilian coast have been described since the 16th century. Many have disappeared as a result of urban development and intensive mining for construction fill and lime production. They occur all along the extensive Atlantic Coast, usually clustering in rich bays or lagoons, where a range of land and aquatic resources is available. Sambaquis are more common along the southern Brazilian coast, from Río de Janeiro to Santa Catarina, including Paraná and São Paulo (Gaspar, 1998, 2000; Lima and López Mazz, 1999; Prous, 1992). Shell mounds farther north have only occasionally been described (e.g., Bandeira 2008; Calderón 1964; Simões and Correa 1971), while the mounds become smaller and infrequent south of this region (Pestana 2007; Rogge and Schmitz 2010).

The shell mounds typically occur in highly productive bay and lagoon ecotones where the mingling of salt and freshwater supports mangrove vegetation and abundant shellfish, fish, and aquatic fowl. The Sambaquis cultural tradition spans a time interval roughly between 8000 and 1600 years ago, but the bulk of radiocarbon determinations on coastal shell mounds are concentrated between 5000 and 2000 cal yr BP — "the golden age" of the Sambaquis culture (Gaspar et al. 2008; Lima 2000; Prous 1992). Along the Atlantic Coast of Río Grande do Sul in Brazil and Uruguay, the mounds were replaced by the Cerritos cultural tradition.

\section{Pantanal}

During the mid-1990s, an attempt to map the largely unexplored region resulted in the documentation of 200 archaeological sites across an area of $20,000 \mathrm{~km}^{2}$ around the city of Corumbá in Mato Grosso do Sul state, Brazil (Schmitz et al. 1998), which 
began to fill the vacuum of archaeological information for this crucial region at the crossroads of Amazonia and the Río de la Plata.

As in the wetlands of southeastern Uruguay (Iriarte 2013), the Llanos de Moxos in Bolivia (Lombardo et al. 2013), and the Paraná Delta (Bonomo et al. 2011b), mounds in the Pantanal are easily recognized as forest islands via remote sensing. Occupation of the Pantanal goes back to circa 9200 cal yr BP, as evidenced by a preceramic site located on the terraces of the Paraguay River. After a hiatus of around 4200 years, the preceramic component of mounds dated to $5000 \mathrm{cal} \mathrm{yr} \mathrm{BP}$ began to appear in low-lying wetland areas, followed by the ceramic component around 2200 cal yr BP (Schmitz et al. 1998). Peixoto et al. (2001) have suggested that the more intense occupation of the Pantanal was related to the stabilization of the region's lakes and fluvial channels, which started during the mid-Holocene around $5000 \mathrm{cal}$ yr BP; recent palaeoecological work has confirmed this (Whitney et al. 2011).

The first millennium BC marks the beginning of the ceramic Pantanal tradition (Schmitz et al. 1998). In the municipalities of Corumbá and Ladário, intensive archaeological survey has revealed a major increase in the number of Pantanal tradition sites. The definition of a new ceramic tradition highlights the need to start from the very basics of cultural chronology in many of these regions. The Pantanal tradition encompasses four different phases defined by technological characteristics: Pantanal, Jacadigo, Castelo, and Taimã (Migliacio 2000; Rogge 2000; Schmitz et al. 1998). These ceramic "styles" are not restricted to the Brazilian Pantanal (De Oliveira 2004, p. 45) but also are present in the Bolivian Pantanal, the Argentinian Chaco, and Paraguay (e.g., Rodríguez 1992; Willey 1971). Regional differences in pottery styles across this vast region are likely to come into closer focus as research progresses. For example, Schmitz et al. (2009) argue that there are slight differences between the left and right margins of the Paraguay River in the temper and external surface finishing of the pottery, as well as in bone point morphology.

\section{Constructores de Cerritos}

Mound-building pre-Columbian cultures date back to circa $4750 \mathrm{cal} \mathrm{yr} \mathrm{BP}$ and generally are referred to in Uruguay as Constructores de Cerritos; they represent one of the less mature Early Formative cultures of South America. The Cerritos are divided into two main periods: the preceramic mound period from around 4750 to $3000 \mathrm{cal}$ yr BP, followed by the ceramic mound period (Iriarte 2006a, p. 648, fig. 2). This archaeological culture extended along the coastal and inland wetlands and grasslands on the Atlantic Coast between $28^{\circ}$ and $36^{\circ} \mathrm{S}$ (Bracco et al. 2000a; Iriarte 2003; Schmitz et al. 1991). The region is characterized by a patchwork of closely packed environments including wetlands, wet prairies, grasslands, riparian forests, stands of Butia palms, and the Atlantic Ocean sand dunes and lagoons (Iriarte and Alonso 2009; López Mazz et al. 2014). 


\section{The Late Holocene}

During the Late Holocene many regions of lowland South America experienced population growth and regional integration, as well as a marked increase in monumental constructions, the development of regional ceramic styles, and longdistance population expansions. Lowland societies also began to transform the landscape at a scale not previously seen. From French Guiana to southern Chile, extensive agricultural landscapes began to be built, such as raised-field systems in seasonally flooded savannahs. Human-made soils-anthropogenic dark earthspossibly associated with more sedentary settlements, and later with more intensive agriculture, began to appear along the bluffs of major rivers in Amazonia (Bush et al. 2008; Denevan 2001; Heckenberger and Neves 2009; Iriarte 2009).

During the late Holocene the La Plata basin constituted a geographical enclave where major cultural traditions from the tropical forests, like the Tupiguarani (Brochado 1984; Noelli 1998), the Goya-Malabrigo archaeological entity-possibly related to Arawak people (Métraux 1934; Nordenskiöld 1930; Politis and Bonomo 2012, 2015) — and the Southern Jê (Iriarte et al. 2008a; Noelli 2005) converged and interacted during pre-Columbian times.

The arrival of these external influences does not necessarily mark an abrupt break with the mid-Holocene cultures of the region. For the Sambaquis, the arrival of Southern Jê influences seems to have been a complex process involving population replacement in some areas and the adoption of ceramics by local groups in others (DeBlasis et al. 2014; Okumura and Eggers 2005). Similarly, the Tupiguarani advance over the La Plata basin was marked not only by conquest and displacement of previous groups, but also by interaction with them, including exchange of objects, styles, and possibly people, especially in ecotone regions (e.g., Chmyz and Sauner 1971; DeMasi e Artusi 1985; Ribeiro 1991; Rogge 2005; De Souza et al. 2016).

\section{Southern Proto-Jê}

During the last two decades there have been major developments in the archaeology of the southern Brazilian highlands in relation to the Taquara/Itararé tradition. First defined by Menghin (1957) as El Doradense in Misiones Province, Argentina, this archaeological tradition was known as Itararé and Casa de Pedra in Paraná (Chmyz 1967) and Taquara in Santa Catarina and Río Grande do Sul states (Miller 1967). More recently, Beber (2005) used the term Taquara/Itararé to refer to this broadly defined archaeological tradition.

Recent studies by archaeologists (DeMasi 2009; Noelli 2005), anthropologists (Silva 2001), and historians (Dias 2005) emphasize the historical continuity between the Taquara/Itararé tradition and the Southern Jê historic groups. We use the prefix "proto" to encompass all the ancestors of modern Southern Jê people in this tradition, including the former speakers of the extinct Southern Jê languages: Ingain and Kimdá (Jolkesky 2010).

The Taquara/Itararé tradition that is the material correlate of Southern Proto-Jê groups dates back to c. $2220 \mathrm{cal} \mathrm{yr} \mathrm{BP}$ and extends to the beginning of the 19th 
century. It is mainly characterized by its diagnostic small ceramics with thin walls, the construction of subterranean houses (hereafter called pit houses) in the highlands, collective burials in caves, rock art, and elaborated mound and enclosure complexes (e.g., Araújo 2007; Beber 2005; DeMasi 2009; Iriarte et al. 2013; Noelli 2005; Ribeiro 1999/2000; Riris and Corteletti 2015; Schmitz 1999/2000). Beyond the general label of Southern Proto-Jê and its shared material culture, there is increasing recognition that this broadly defined tradition spread over a vast area (more than $600 \mathrm{~km}$ north to south) encompasses a remarkable range of local variability in social and ritual organization. This is exemplified by the Canoas and Pelotas River basins (Copé 2007; Corteletti et al. 2015; DeMasi 2009; De Souza and Copé 2010; Iriarte et al. 2013; Schmitz et al. 2010; 2013b), Misiones Province, Argentina (Iriarte et al. 2008a, 2010; Menghin 1957; Riris 2015), the Atlantic Coast (Silva et al. 1990), the Atlantic forest escarpment (Farias et al. 2015), the north of Paraná state (Araújo 2001; Parellada 2005), and the southern portion of the southern Brazilian highlands (Copé 2006, 2007; Copé et al. 2002; Corteletti 2008; Schmitz et al. 2002).

Archaeological projects during the last two decades have begun to reveal general chronological trends in the development of the Southern Proto-Jê. Available radiocarbon dates indicate that Taquara/Itararé sites began to spread in the second millennium BP, becoming more common around $1500 \mathrm{cal}$ yr BP and peaking after around $1000 \mathrm{cal}$ yr BP (Fig. 2). Around $1000 \mathrm{cal}$ yr BP, we also see the appearance of mound and enclosure complexes and oversized pit structures (Copé 2006; Corteletti 2012; Iriarte et al. 2013; Schmitz et al. 2013a); significantly, this appearance coincided with the expansion of Araucaria angustifolia (Paraná pine) as evidenced by pollen records along the southern Brazilian highlands (Iriarte and Behling 2007; see Gessert et al. 2011, p. 30, fig. 1).

\section{The Tupiguarani}

The investigation of population expansions in the past-and the correlation with existing distributions of archaeological sites, contemporary languages, and human population genetics-is one of the most controversial topics in linguistics, archaeology, and human genetics in lowland South America (e.g., Heckenberger 2002; Hornborg 2005; Neves 2011; Politis and Bonomo 2012; Santos et al. 2015). The expansion of the archaeologically defined Tupiguarani tradition along some $5,000 \mathrm{~km}$ of the Atlantic Coast and through the major rivers in the hinterland represents one of the major migrations in the lowlands of South America during the Late Holocene (Bonomo et al. 2015; Brochado 1984; Noelli 1998).

The greatest diversity of Tupian languages is found in the southwestern Amazon. Consequently, most linguists point to this region (around the modern Brazilian state of Rondônia) as the center of origin of this linguistic stock, which had started to expand around 4,000-5,000 years ago (Migliazza 1982; Rodrigues 1984; Storto and Moore 2001; Urban 1992; Walker et al. 2012). Recent craniometrics studies (Neves et al. 2011) also point to an Amazonian origin of Tupí-Guaraní speakers. Interestingly, the purported homeland of the Tupian stock in the southwestern Amazon has one of the longest cultural histories in the entire Amazon. Early 

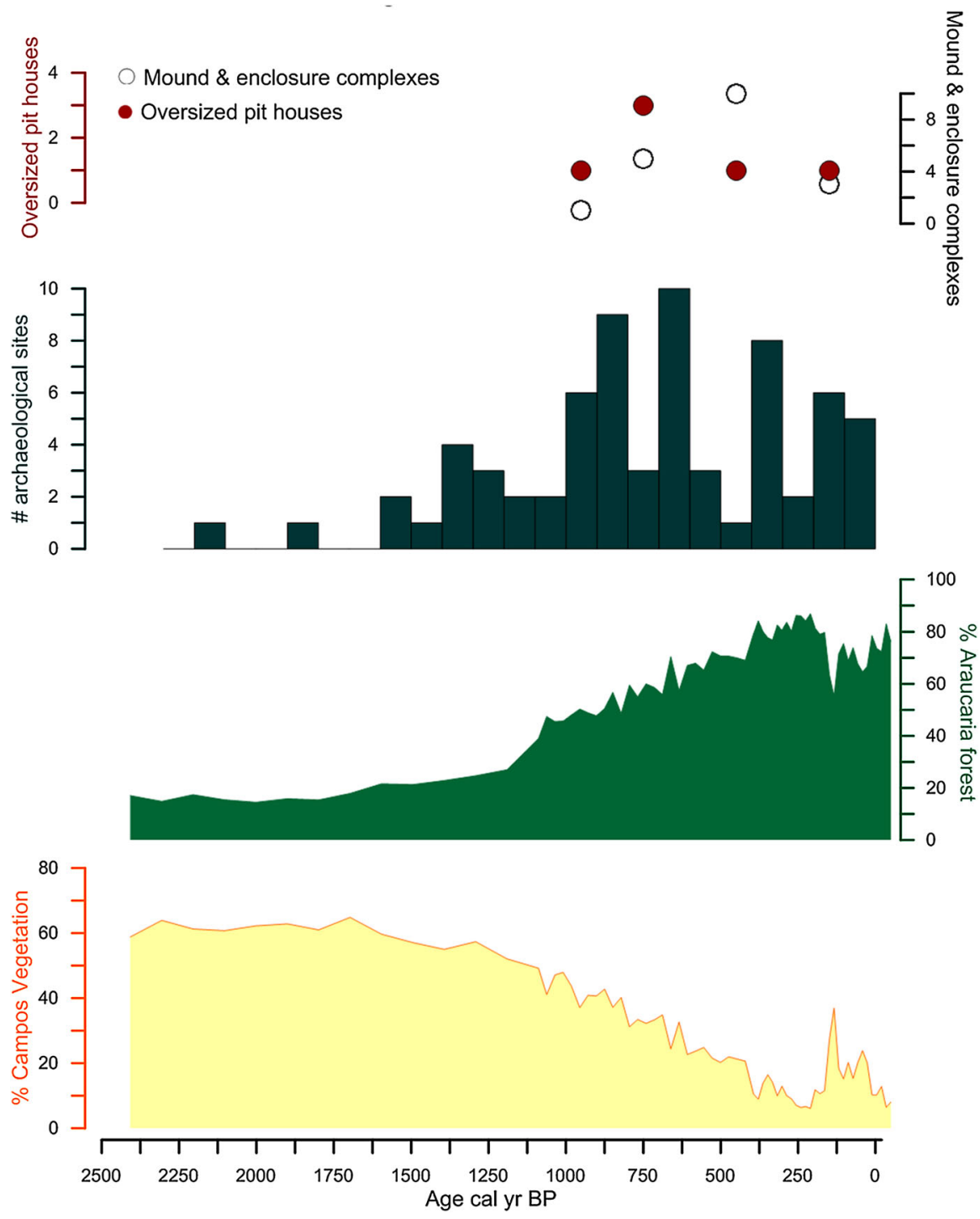

Fig. 2 Composite graph showing dates of all archaeological sites, mound and enclosure complexes, and oversized pithouses combined with Araucaria forest and Campos (high-altitude grasslands) pollen curves from Cambará do Sul record (Behling et al. 2004). The composite graph illustrates the correlation of major cultural transformations (increase in archaeological sites, appearance of oversize pit houses, and the arrival of monumental architecture) with the expansion of Araucaria forest.

Holocene shell middens have recently been discovered in the Llanos de Moxos (Lombardo et al. 2013) and the Brazilian Guaporé River (Miller 1992, 2013), while other evidence includes the presence of 5,000-year-old anthropogenic dark earths, one of the earliest centers of pottery production-dated to around 4,000 cal yr BP 
(Miller 1992, 2009, 2013)—and the likely cradle of manioc (Manihot esculenta) domestication (Olsen and Schaal 1999).

The earliest material correlates for the Tupian speakers in southwestern Amazonia remain a matter of discussion (Almeida 2013; Almeida and Neves 2015; Cruz 2008; Miller 2009). Although early syntheses postulated that the Tupiguarani pottery was derived from the Amazon polychrome tradition (Brochado 1984), refinements in chronology and stylistic analyses suggest it was an earlier, though related development (Almeida 2013; Heckenberger et al. 1998). Pottery clearly identifiable as Tupiguarani appears in the archaeological record around 2700 cal yr BP (Corrêa 2014, p. 255); this broadly coincides with the linguistic estimate, based on glottochronology, for the beginning of the Tupí-Guaraní diaspora (e.g., Rodrigues 1964) around 2,500 years ago.

Despite this unresolved debate, it is clear that at least by around 2000 cal yr BP groups carrying Tupiguarani ceramics arrived in the southeastern sector of the Río de La Plata basin and started colonizing and establishing large villages in forested areas along the major river courses (Bonomo et al. 2015; Brochado 1984; Prous 1992). Based on the linguistic distribution of the ancient Guarani family, mainly restricted to the southeastern sector of the Río de La Plata basin and the adjacent Atlantic Coast, the Tupiguarani have been renamed the Guarani archaeological tradition (Bonomo et al. 2015). The archaeological correlates of the Guarani archaeological tradition are more restricted and include ceramic dishes, shallow bowls, and large jars with restricted orifices and conical bases; vessels with corrugated, nail-incised, brushed, or painted surfaces; lip plugs; polished stone axes; secondary burials in urns; and bounded, dark terra preta sediment, associated with households and other architectural structures (Bonomo et al. 2015, p. 55). In addition to these material traits was a preference for subtropical deciduous forest environments close to navigable rivers and the practice of polyculture agroforestry, including the management of old fallows and secondary forests (Scheel-Ybert et al. 2014).

\section{Paraná River Delta}

The region of the Paraná Delta has received renewed archaeological interest, in particular in relation to the Goya-Malabrigo archaeological entity (Cerutti 2003; Politis and Bonomo 2012) and the archaeology of complex hunter-gatherers adapted to the lower Paraná River wetlands. Although the region was the focus of archaeological investigations at the end of the 19th century (Ambrosetti 1893) and the first part of the 20th century (e.g., Bonomo 2013; Lothrop 1931; Torres 1911), archaeological research in the region was stagnant until the last decade (see Bonomo et al. 2011a). New research on the Goya-Malabrigo is reframing old research agendas, mainly based on chronology and the definition of ceramic styles, to discuss incipient social hierarchy and the development of early village life, as well as the role of cultigens in the diet of these Late Holocene groups. The earliest date from mound contexts associated with the Goya-Malabrigo in the middle Paraná River is c. 2025 cal yr BP (Arroyo Aguilar 2) (Politis and Bonomo 2012, 2015), though most of the dates show a more intense occupation of the Paraná Delta and 
the lower Uruguay River between $1200 \mathrm{cal} \mathrm{yr} \mathrm{BP}$ and the time of European contact (Bonomo et al. 2011a; Politis and Bonomo 2015). Goya-Malabrigo, previously known as Ribereños Plásticos, has recently been more strictly defined. This new definition is based on the diagnostic morphological and stylistic features found in its ceramics, as well as the construction of artificial mounds, the existence of a mixed economy and riverine settlement patterns, and a close relationship (technical, economic, constructive, and cosmological) with clay (Politis and Bonomo 2015). Diagnostic ceramics include globular vessels; modeled zoomorphic adornos affixed to bowl rims representing bird heads, mammals, reptiles, and mollusks; and the unique alfarerias gruesas represented by bell- or tubular-shaped objects of thickwalled pottery. The objects usually exhibit drag and jab punctuations, incisions, rows of punctate dots, and fingernail impressions. Red and white slip also is common (Cerutti 2003, pp. 118-123; Politis and Bonomo 2012). According to Politis and Bonomo (2015), the zoomorphic adornos demonstrate the incorporation of animals into the sphere of cultural representations, where birds played a prominent role.

\section{Emergence of Social Complexity}

The emergence of cultural complexity has been a key topic in the study of the dynamics of intermediate-level societies (sensu Upham 1990) (e.g., Arnold 1996; Brumfiel and Fox 1994; Enrenreich et al. 1995; Price and Brown 1985; Price and Feinman 1995). Reevaluations of progressivist typological frameworks (Fried 1967; Service 1962) have recognized that a degree of inequality exists even in the most egalitarian societies (Cashdan 1980; Collier and Rosaldos 1982; Flanagan 1989; McGuire and Paynter 1991), that the origins of agriculture are not intrinsically related to the emergence of cultural complexity (Arnold 1996; Koyama and Thomas 1981; Price and Brown 1985; Price and Gebauer 1995; Upham 1990), and that there is more social variability among Early Formative societies than previous neoevolutionary concepts of sociocultural complexity had accounted for (Baker 1996; Blanton et al. 1996; Drennan 1991,1995; Nelson 1995). These reconceptualizations demonstrate that different aspects of cultural complexity, such as inequality, differentiation, scale and integration, and their correspondent list of archaeological correlates (Creamer and Haas 1985; Peebles and Kus 1977), do not necessarily covary from one stage of cultural evolution to the other; neither do they all need be present in every Early Formative society. On the contrary, social variation in Early Formative societies can be understood to have been multidimensional and continuous (Feinman and Nietzel 1984; Plog 1974; Upham 1987; Yoffee 1993). In response to these reevaluations, archaeologists over the last two decades have begun to look beyond neo-evolutionary frameworks that stress functionally oriented ecological and economic explanations, turning instead to considerations of ideology, power, and factional competition while adopting a more historically based approach (e.g., Canuto and Yaeger 2000; Chapman 2003; Clark and Blake 1994; Dietler 2001; Parkinson 2002; Pauketat 2001). These perspectives differ from oppositional views of simple/egalitarian versus complex/hierarchical, in that other 
concepts are employed. Actor-based perspectives (e.g., Clark and Blake 1994), heterarchy (Crumley 1987), and situationalism are explored, along with network and corporate strategies (Blanton et al. 1996), communalism (Saitta 1997), and a more flexible concept of tribal societies as defined by Parkinson (2002). As a result, most archaeologists today recognize various pathways to emergent complexity and employ various models to explain it. They recognize that social power is constructed in significantly different ways by aspiring political actors involving competitive strategizing, which may include feasting (e.g., Clark and Blake 1994; Hayden 1995), the practice of extensive or intensive agriculture (e.g., Drennan 1995; Gilman 1991), participation in long-distance exchange and craft production of luxury goods (e.g., Helms 1994), warfare (Redmond 1994), the appropriation of the means of expressing ideological knowledge (e.g., Aldenderfer 1993; Drennan 1976; Earle 1991), and/or the combination of many of the above (e.g., Spencer 1994). Under this more productive and informative approach, archaeologists have focused their efforts on understanding how these societies became complex, rather than simply trying to define how complex they were (Nelson 1995).

Many of these new approaches concentrate on more particular historical developments (e.g., Pauketat 2001) and incorporate the concepts of practice (Bourdieu 1977) and structure (Giddens 1979) into their interpretations of specific historical trajectories. At the same time, aspects relating to the perception, memory, ideology, and underlying structural principles and meanings of Early Formative landscapes are taken into account (e.g., Ashmore and Knapp 1999; Barrett 1996; Bradley 1998; Dillehay 2007; De Boer 1997; Edmond 1999; Feinman 1999; Iriarte et al. 2013; Thomas 1999; Tilley 1995); several authors have emphasized the importance of the landscape as a means of encapsulating and transmitting historical memory (e.g., Bender 1993, 2002; Criado Boado et al. 2006; Santos-Granero 1998, 2004).

Despite decades of culture history approaches, archaeologists in the Río de la Plata basin have only recently begun to discuss different aspects of emergent social complexity beyond the simple categorization of archaeological traditions into evolutionary categories (e.g., Gaspar 1998; Iriarte et al. 2004; Lima and López 1999; Politis et al. 2011). In some regions, such as the Pantanal, much research still focuses on defining new cultural traditions. But in others, such as the southern Brazilian highlands, archaeology has reached a maturity where we can now move to more nuanced interpretations and conceptual issues beyond cultural chronology and discuss emergent cultural complexity along the lines of regional settlement patterns, site-level community patterns, mound uses, construction history and architecture, mortuary practices, and subsistence economy. As a result of decades of sustained systematic archaeological research coupled with new methodological advances, we can now begin to reconstruct regional settlement patterns of the Cerritos in the Campos region (e.g., Gianotti and Bonomo 2013; Iriarte 2006a, 2013). At the site level, archaeologists' interests in revealing community patterns or recurrent architectural patterns in complex sites, beyond the study of single mounds or pit houses, also are paying dividends by showing recurrent patterns of community organization (Gianotti and Bonomo 2013; Iriarte 2006a, 2013). Advances also have been made on the documentation of mound-building practices and the uses of 
mounded architecture (e.g., Bonomo et al. 2011a; Castiñeira et al. 2014; DeBlasis et al. 2007; DeMasi 2009;). Renewed excavations, more comprehensive radiocarbon chronologies, detailed faunal analysis, artifact composition and density trends, and the novel application of micromorphology and phytolith analysis are revealing more complex construction histories than previously reported (e.g., Castiñeira et al. 2014; Iriarte 2003; Suárez Villagran and Gianotti 2013). Last but not least, the subsistence economy of these groups is also beginning to be revealed. Archaeobotany is still in its nascent stages in the Río de La Plata basin (Iriarte 2007). The systematic implementation of new archaeobotanical methods, in particular microfossil botanical analyses (phytolith, pollen, starch grains, and charcoal), is leading to a better understanding of the plant component of diets and the role of domesticated plants, which has implications for our understanding of the economy and mobility of these groups (Bonomo et al. 2011b; Corteletti et al. 2015; Iriarte et al. 2004; López Mazz et al. 2014), as well as the ritual aspects (Iriarte et al. 2008a). The role of maize in the diet of groups such as the Goya-Malabrigo and Tupiguarani of the Paraná Delta is also beginning to be revealed through stable carbon isotope analysis (Loponte and Acosta 2007).

Here we present a summary of new findings that touch on the aspects of the emergence of social complexity. We discuss different aspects of emergence complexity in terms of regional settlement patterns, site-level community organization, earthwork use and construction history, mortuary practices, and subsistence economy.

\section{Constructores de Cerritos}

In southeastern Uruguay, aerial photography has played a major role in the documentation of settlement patterns, aided by earthen mounds that are highly visible on aerial photographs (Bracco and López Mazz 1989; Iriarte 2013). At a macroregional scale, encompassing the entire Cerritos region, Bracco (2006, p. 513; fig. 1) has shown how the largest aggregations are located on the middle and upper course of streams. Bracco et al. (2005) estimated the existence of around 1,500 mounds within the Uruguayan southern sector of the Laguna Merin basin $\left(30,000 \mathrm{~km}^{2}\right)$. Similarly, in northeastern Uruguay, Giannotti (2004) has documented the presence of 1,023 mounds, consisting of 97 clusters of different sizes with large (50-80), medium (15-30), and small (2-5) clusters of mounds (Gianotti 2000, 2005; Gianotti and Bonomo 2013, p. 131).

The India Muerta wetlands are one of the more intensively studied areas (Fig. 3). Investigations in the early 1990s documented the presence of numerous large and spatially elaborated mound complexes, some of them, like Estancia Mal Abrigo, consisting of 66 mounds; these investigations firmly established the beginning of the preceramic mound period at around 4,750 cal yr BP (Bracco 2006; Iriarte et al. 2001). Settlement pattern research revealed that mound sites are confined to wetland floodplains in ecotonal areas characterized by fertile soils within a mosaic of wetlands, wet prairies, grasslands, riparian forests, and palm groves (Bracco 2006). A more nuanced analysis by Iriarte $(2003$, 2006a) revealed a dual distribution pattern for mound sites in this region. Small sites (1-3 mounds) generally occur in 


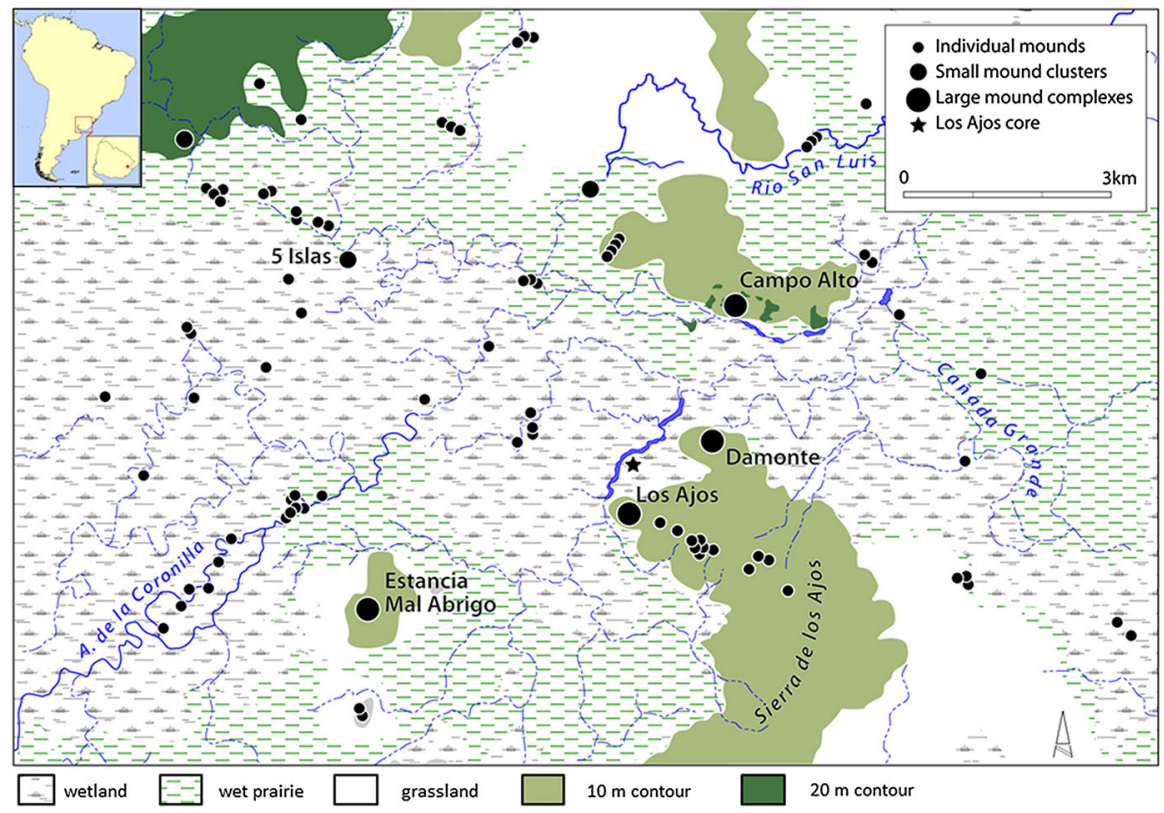

Fig. 3 Distribution of mound sites in the India Muerta wetlands in the southern sector of the Merin Lagoon, Uruguay.

the wetland floodplains on top of the most prominent levees following the courses of streams and exhibiting a linear/curvilinear pattern. In contrast, in the more stable locations of the landscape, such as the flattened spurs of hill ranges (e.g., the Sierra de los Ajos) adjacent to wetland floodplains- which are secure from flooding and have immediate access to resource-rich and fertile wetlands-mound sites are large, numerous, and spatially complex, covering up to 60 ha. In the nuclear sector of this region, the average distance between large mound complexes is less than $2 \mathrm{~km}$ (Bracco 2006).

Community patterns or the lack of them have been at the center of discussions about the complexity of the Cerritos. During the first archaeological reconnaissance of the region in the mid-1960s, archaeologists interpreted mound sites as the result of successive short-term occupations of hunters, gatherers, and fishers who moved seasonally to exploit locally rich environments (Brochado 1984; Schmitz et al. 1991). The presence of postholes and hearths, domestic debris food preparation, tool manufacture and maintenance, and occasional burials were used to infer the habitation nature of the mound. In the mid-1980s, the Archaeological Salvage Program of the Laguna Merin Basin (CRALM) began systematic archaeological fieldwork in Uruguay. Initial excavations on small two-paired mound sites, which yielded complex arrays of ceramic mound period multiple burials, led the researchers to characterize these sites as ceremonial and/or mortuary in nature (Cabrera et al. 1989). The societies were typified as complex hunter-gatherers adapted to a resource-rich wetland environment (López Mazz and Bracco 1994). The researchers began to recognize the presence of large mound complexes with a 
high degree of similarity in ground plan, as well as the presence of an extensive offmound area associated with the mounds (López Mazz and Gianotti 1998). In 1996, the Arqueología de las Tierras Bajas international conference included the participation of archaeologists investigating Early Formative societies from across the Americas (Durán and Bracco, 2000). This provided the much-needed panAmerican comparative perspective that enabled Uruguayan archaeologists to start viewing the Cerritos not as simple or complex hunter-gatherers but as intermediatelevel societies living in well-planned villages (Dillehay, n.d.). Subsequently, the investigation of community patterns has become a prolific focus of research. It was recognized that these sites contain varied mounded architecture geometrically arranged in circular (e.g., Estancia Mal Abrigo), elliptical (e.g., Damonte), and horseshoe formats (e.g., Los Ajos), surrounding a central communal space and accompanied by vast outer sectors that generally exhibit more disperse and less formally integrated mounded architecture (Fig. 4; Bracco et al. 2000b; Iriarte 2003, 2006a, 2013; Iriarte et al. 2001; López Mazz and Gianotti 1998). Bracco (2006, pp. 520-521, figs. 8 and 9) shows how within the sites the orientation of the mounds and the distance between them are fairly regular, reinforcing the idea that these were well-planned settlements. Giannoti and Bonomo (2013, p. 136, fig. 2) have recorded similar patterns in northeastern Uruguay, where a parallel linear arrangement, suggesting dual symmetrical organization, also has been identified (e.g., Echenagusía site).

In addition, the interpretation of the uses and construction history of mounds in the region has been subject to debate in relation to the habitation versus ceremonial nature of these earthen structures (Bracco et al. 2008; Iriarte et al. 2008b), with implications for cultural complexity.

Originally interpreted by Programa Nacional de Pesquisas Arqueológicas (PRONAPA) researchers in the early 1970s as the domestic spaces of mobile hunter-gatherers (Schmitz et al. 1991), the features were considered by Uruguayan archaeologists to be the burial mounds of complex hunter-gatherers (López Mazz

A

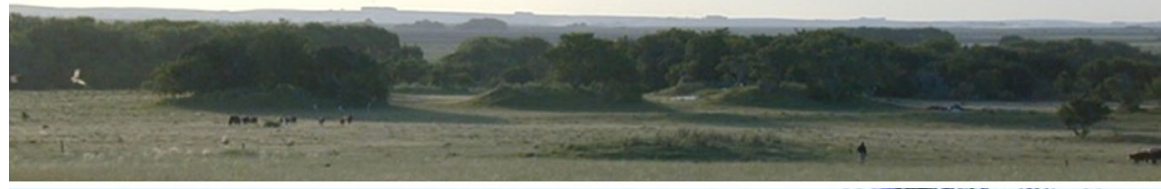

B

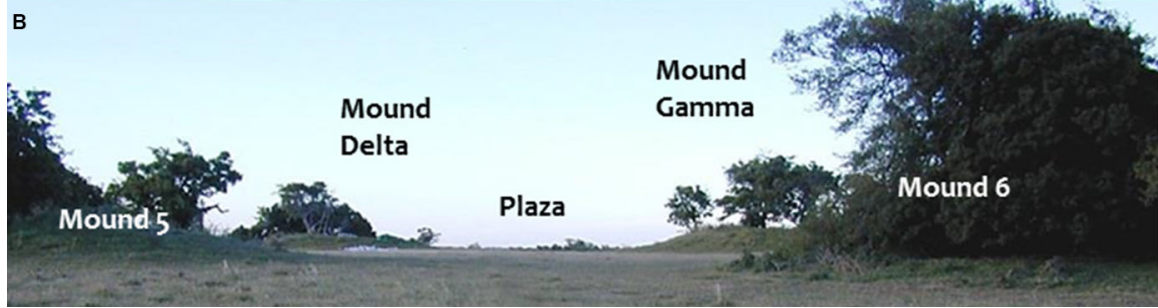

Fig. 4 Los Ajos mound complex: A, panoramic view; B, view of the inner precinct showing circular arrangement of mounds around the central plaza. 
and Bracco 1994). Influenced by landscape archaeology approaches (Criado Boado 1993), the appearance of mounds was seen to reflect a major breakthrough in the history of hunter-gatherers in the region, with the onset of mound-building practices perceived as an innovative behavior where groups "show the intention" to monumentalize the landscape by constructing ceremonial/monumental architecture (Gianotti 2000; López Mazz 2001; Pintos 2000a). López Mazz (2001, p. 237) views the beginning of mound construction as "...a novel cultural behavior of midHolocene specialized hunter-gatherers that started building mounds in strategic locations of the landscape previously characterized as hunting camps"; the first mounds were the product of highly mobile preceramic hunters-gatherers who had long hunted in the region. According to López Mazz, possible functions of these older mounds was to serve as territorial markers that signaled exploitation rights to zones of concentrated resources and to facilitate travel in this flooded landscape. In a similar vein, Gianotti (2000, p. 90) interpreted the earthen structures as monuments that represent the first evidence of "an effective transformation of the natural environment, the narrowing of the breach that exists between nature and culture" (see also Criado Boado et al. 2006). Furthermore, Pintos (2000a) suggested that the construction of mounds in the Laguna de Castillos basin should be interpreted as the appearance of monumental architecture. Since mounds contain burials, they conform to a landscape "connoted by the monumentalization of the dead" (Pintos 2000a, p. 78). Following Vincent (1991), Pintos sees in the monumentalization of the death of certain individuals as the historic consolidation of a new social order, where ancestors played a major role. This change reflects the transition from a classificatory to a lineage system of kinship relations (sensu Meillaisoux 1978).

As investigations continue in the region, the complex relationship between episodes of construction, maintenance, remodeling, and reuse of pre-existing mounds is becoming clearer (Bracco et al. 2000b; Iriarte 2006a; López Mazz et al. 2014; Suárez Villagran and Gianotti 2013). There is also increasing recognition that the dominant function or behaviors that created the mounds shifted over time (e.g., Bracco et al. 2000b; Iriarte, 2006a; Suárez Villagran and Gianotti 2013). For example, excavations at the Los Ajos sites revealed a complex construction history and varied uses of mounds throughout their use life. The combined analysis of stratigraphy, artifact and ecofact composition, and horizontal spatial distribution of lithic debitage density showed that during the preceramic mound component, Mound Gamma was a residential area that grew through the gradual accumulation of occupational refuse. Despite intensive excavation in the center of the mound, no clear house features were identified. However, horizontal density trends of lithic debitage showed a consistent pattern, characterized by the presence of a central area of low density and a periphery exhibiting higher artifact density. The central zone of the mound has been interpreted as a regularly maintained habitation space and the periphery as a zone where trash was deposited (Iriarte 2003, 2006a). The lithic assemblage indicates that tool manufacture, use, and maintenance took place at Los Ajos. Local raw materials, mainly rhyolite and quartz, were brought to the site, where all stages of lithic reduction are represented, including core reduction, tool manufacture and use, and maintenance/rejuvenation. The generalized, nonspecific 
tool assemblage comprises a broad range of different tool types that include flake knives, end scrapers, wedges, notches, points/borers, and hafted bifaces; they indicate that Mound Gamma was a domestic area where a wide range of activities were carried out (Iriarte 2003; Iriarte and Marozzi 2009).

Similar complex histories have been recorded at the Lemos and Pago Lindo mound sites in northeastern Uruguay. The presence of hearths, postholes, and linear structures possibly associated with small constructions shows the domestic nature of the Lemos site, which was occupied between 3485 and $3280 \mathrm{cal}$ yr BP. The mound was remodeled during the ceramic period (Gianotti and Bonomo 2013). Micromorphological analysis at the Pago Lindo archaeological complex has also recognized a distinct activity area interpreted as a domestic hut built over a platform, circa 1485 cal yr BP (Suárez Villagran and Gianotti 2013). As with the artifact density analysis of the Los Ajos preceramic mound component, these researchers interpreted the presence of a small quantity of macroscopic bone and charcoal fragments, and the complete absence of microbioarchaeological remains, as evidence of the regular practice of cleaning the occupation surfaces at the center of mounds. Excavations in northeastern Uruguay corroborate the fact that mounds started as habitation structures that grew intentionally or unintentionally through the gradual accumulation of domestic refuse.

Research is also showing that during the succeeding ceramic mound period (c. 3280-500 cal yr BP) there was a marked increase in the number of sites, the appearance of collective cemeteries, and a formalization and spatial differentiation of the earthen mound architecture. This appears to represent an early and distinct civic-ceremonial architectural tradition in lowland South America (Iriarte 2006a; Iriarte et al. 2004). The accretional residential mounds were the backdrop for these activities. For example, during the preceramic component in the Los Ajos mound complex, we saw the appearance of a household-based community distributed around a central public space; the ceramic mound component, however, witnessed the appearance of internal site stratification, characterized by the formalization and spatial differentiation of the inner precinct with respect to an outer, more dispersed and less formally integrated peripheral area. Low, circular, dome-shaped mounds were transformed into more imposing quadrangular platform mounds through gravel capping episodes. Similar practices were documented at the Puntas de San Luis mounds, where burnt chunks of termite mounds were used as construction material during the ceramic mound period to heighten and reshape mounds (Bracco et al. 2000b). Earthen architecture also served as funerary monuments, which represent first-order elements for the social construction of the landscape (Bonomo and Gianotti 2013; Criado Boado et al. 2006). In sum, research designs specifically tailored to reveal community patterns have been successful in showing that the large preceramic mound complexes in the India Muerta wetlands were neither the result of random, successive short-term occupations of mobile hunter-gatherers (Schmitz et al. 1991), nor the burial mounds or monuments of complex hunter-gatherers, as previously proposed (Bracco et al. 2000a; Gianotti 2000; López Mazz 2001). Instead they were well-planned plaza villages built by people who practiced a mixed economy (see below). 
Burials in mounds appeared around the first millennium $\mathrm{BC}$, during the later preceramic mound period. A diversity of primary and secondary burials is evident, including bundles, isolated bone fragments with signs of trauma (e.g., cut marks, intentional fractures, burnt alteration) (Gianotti 1998; Gianotti and López Mazz 2009; Pintos and Bracco 1999), and the presence of animals including dogs (Canis familiaris) (Criado Boado et al. 2006).

No clear signs of differential burial practices have been recovered for the Cerritos. One of the more intensively studied sites is CH2D01, consisting of twopaired mounds. More than 40 individuals were recovered, including three bundle burials: two of the burials represented two males while a third contained two heads, one male and one female. Analysis by Femenías and Sans (2000) found no significant differences in the material culture associated with the burials and argued against the restriction of high-status differentiation to a few individuals. Data from several excavations in the region also suggest that the upper parts of the mounds were built as a corporate burial facility designed to reinforce kinship, clan, or community ties rather than to mark the death of a single, important individual.

In addition, the application of systematic archaeobotanical analyses has changed how we view the economy of these groups and has been used to document the earliest adoption of cultigens in the region. At the Los Ajos site, plant and animal remains indicate the adoption of a mixed economy shortly after people began to live in more permanent villages. Phytolith and starch grain analyses of seeds, leaves, and roots from a variety of wild and domesticated species uncovered the earliest occurrence in the region of at least two domesticated crops: corn (Zea mays) and squash (Cucurbita spp.), which appeared shortly after 4750 cal yr BP (Iriarte et al. 2004). The close association between large mound complexes and the most fertile agricultural lands in the region suggests that people likely practiced floodrecessional farming during the preceramic mound period. During the spring and summer months, organic soils are exposed on the wetland margins; these superficial peat horizons are highly fertile, hold moisture, and are easy to till. In addition, the floodwater of the nearby Cebollatí River periodically inundates the area and replenishes the soils with nutrients. The India Muerta wetlands are thus an ideal location for wetland margin seasonal farming (Iriarte 2003, 2007; Iriarte et al. 2004). The exploitation of palms is evidenced by the recovery of palm nut endocarps from butia (Butia capitata) and pindó (Syagrus romanzoffiana), as well as by the presence of abundant globular echinate palm phytoliths in the basal preceramic mound period at Los Ajos, Isla Larga, and Estancia Mal Abrigo (Iriarte et al. 2001). Dense stands of oligarchic butia palm groves, whether wild, encouraged, or cultivated, constituted an extremely rich seasonal resource for prehistoric populations living in the area (López Mazz et al. 2014). Analyses from different sites in the southern sector of the Lagoon Merin basin and northeastern Uruguay dating back to $4750 \mathrm{cal}$ yr BP also have expanded our knowledge of the use of wild plants including tubers (Canna glauca, Typha dominguensis, Cyperus sp. and Scirpus sp.) and bromeliads (Bromelia sp.), and of the possibly domesticated plants including beans (Phaseolus sp.) and peanuts (Arachis sp.) (e.g., Capdepont et al. 2005; Del Puerto 2015; Del Puerto and Inda 2005; López Mazz et al. 2014). 
Given the formal design of community villages in the Early Formative societies of southeastern Uruguay and the elaboration of public architecture, the lack of archaeological correlates for personal ranking is remarkable. Absent are differential mortuary patterns, specialized craft production, exotic/prestige goods, and/or corporate architecture that may require a body of authority to mobilize and organize large labor pools; the power aspirations of individual political actors may not have been successful. It seems that rituals aimed at reinforcing kinship ties through communal rites neutralized any attempt of individual aggrandizement. These mechanisms may have effectively limited and undermined the degree of political control that the Early Formative group leaders could have maintained over their communities. The archaeological evidence shows that agent-based competitive strategizing activities, such as feasting (e.g., Clark and Blake 1994; Dietler 2001; Hayden 1995, 2001), long-distance exchange (e.g., Helms 1994), or warfare (e.g., Carneiro 1998; Redmond 1994, 1998) did not crystallize in the Early Formative societies of southeastern Uruguay, or at least are not archaeologically conspicuous. Consequently, it is best to conceptualize these Early Formative societies as grouporiented (Renfrew 1974), corporate (Blanton et al. 1996), communal social formations (Saitta 1997) that resisted individual aggrandizers in their path to power (e.g., Lee 1990; Wiessner 2002).

\section{Sambaquis}

Regional studies have been especially fruitful in enlightening the social landscapes of the Sambaqui builders of the Atlantic Coast. Recent research, focused on an area of roughly $692 \mathrm{~km}^{2}$ on the southern coast of Santa Catarina, around the Santa Marta Cape, has investigated the joint evolution of the landscape and the nature of the Sambaqui occupation (DeBlasis et al. 2007; Kneip 2004). Sambaqui builders have been settled around a bay/lagoon system for at least six millennia, with a considerable demographic expansion between approximately 5,000 and 2,000 years ago, seen both in the number of sites and their overall incremental size/volume. Settlement expansion displays a circum-lagoon distribution of site clusters marked by some long-lived mounds and smaller sites. This coeval distribution has been interpreted as face-to-face communities around the lake sharing an essentially aquatic way of life, but also accessing nearby firm-ground hinterland resources. The lack of evidence for centralized power, together with evidence for cultural homogeneity and social integration, sedentariness, and economic intensification, strongly suggests the emergence of a heterarchical social structure. The distribution of mounds dedicated to ancestors points to the sharing of the territory between welltied social units, possibly related to local lineages.

The social glue, based on the sharing of cultural (and, over the southern shores, probably also linguistic) traits, seems to have been provided by a strong overall religious system structured around the cult of ancestors, with strong reciprocity ties among communities. These links seem to have promoted peace and social stability, as well as propitious conditions for intensifying resource production into and around the lagoon. Occasional outstanding burials suggest the possibility of the emergence of more centralized leadership, but they are rare and dispersed. Burial patterns are 
rather homogenous and do not show peculiarities that could be related to gender, age, or even social distinctions.

The nature of their construction also has played a major role in discussion about the complexity of these groups. These shell mounds consist of cultural deposits of varying sizes and stratigraphies, in which shell is a major constituent. These accumulated deposits undoubtedly reflect a range of formative processes. They consist of sequences of sand and shell deposition, both natural and artificial, mingled with darker, more organic layers; they often display features associated with activities that took place on older surfaces, subsequently buried within the mound. While single-layered small sambaquis may contain only a few artifacts and features, possibly representing campsites or processing stations, many others served mortuary functions (Fig. 5). This is the case, in particular, with the massive mounds found on the southern shores, which contain complex stratigraphic sequences (Gaspar et al. 2008). These larger shell mounds exhibit many alternating sequences of shell deposits and narrower, darker layers with plenty of charcoal and (often burnt) fishbone that mark successive occupation surfaces over the mound. The dark layers represent large funerary areas with clusters of burials, hearths, and postholes. Lithic and bone artifacts also are characteristic components of these dark layers, which consist mostly of secondary fill brought from other activity areas outside the funerary context with the purpose of covering the burials (Suárez Villagran et al. 2010). Despite abundant food refuse in the mounds and features (such as earth ovens) that would be expected in domestic contexts, recognizable dwelling areas have not been encountered, neither do the distribution and arrangement of features indicate sustained domestic activity.

Archaeologists now perceive the sambaquis as long-lived monumental structures located in permanent places, highly visible in coastal cultural landscapes, and drenched with symbolic meaning (Fish et al. 2013). This interpretation clashes with previous views that saw them as giant middens or platforms for dry, elevated residences in the context of domestic activities (e.g., Beck 1972; Hurt 1974; Kneip

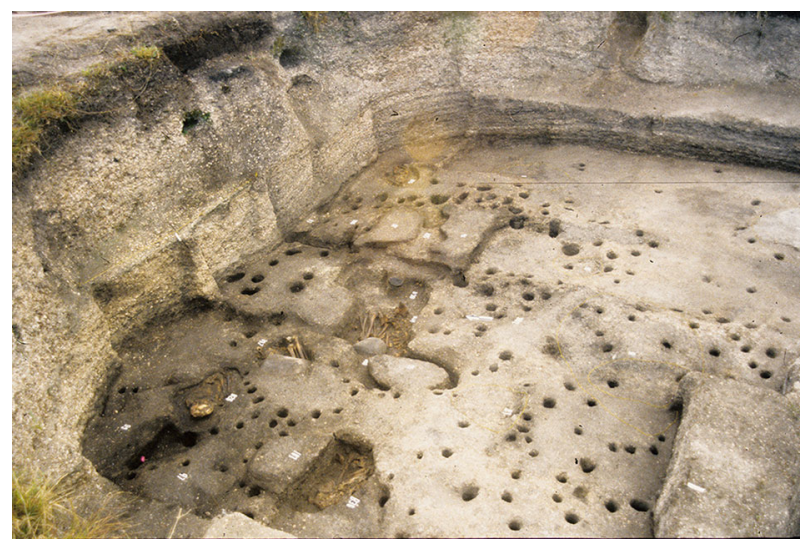

Fig. 5 Jabuticabeira II shell midden showing its complex stratigraphy and the spatial arrangement of burials, postholes, and hearths (courtesy Maria Dulce Gaspar). 
1977; Prous 1992; Rohr 1984). The enduring and socially orchestrated effort necessary to create these huge mounds of shell (up to $50 \mathrm{~m}$ in height and $600 \mathrm{~m}$ in diameter) is certainly not casual or unintentional. Instead, it has created impressive landmarks in which the ancestors are embedded in long-lived sacred landscapes (DeBlasis et al. 1998, 2007; Fish et al. 2013; Gaspar 1998, 2000; Gaspar et al. 2008).

There are funerary areas concentrated in confined spaces in the sambaquis. The bodies are not disposed of at random but in special areas set aside for this purpose. The funeral ritual is elaborated and characterized by the deposition of artifacts restricted to the funeral space and associated with burials (Gaspar 1998; Gaspar et al. 2008). As the burials are placed in areas of intersection of stratigraphic layers, it can be argued that they are directly related to the construction events of the sambaquis, which are characterized by discrete mounded layers and lenses. Funerary structures are generally demarcated by postholes, hearths, and ash lenses, leading Klokler and Gaspar (2013) to argue that the bodies must have been suspended on wooden structures during funeral rites. It is also common to find closed Lucina pectinata shells in association with articulated parts of fish skeletons, such as in the Amourins sambaqui; these have been interpreted as burial offerings (Klokler and Gaspar 2013). Additionally, although there is some evidence of violence recorded in sambaqui skeletal remains, the number of individuals who suffered violent deaths is extremely low, which in turn suggests that warfare did not play a major role in intra- or intergroup relationships (Lessa, 2005; Lessa and de Medeiros 2001). Overall, Mendonça de Souza et al. (2013) conclude that the buried and their contexts are testimonies to the mound builders, the construction processes employed, and how these sites were used, including their symbolic aspects.

Our perception of the economy of these groups is also changing. Sambaquis have traditionally been seen as the remains of successive camping episodes left behind by mobile mollusk-gathering and fishing bands. Recent studies, however, have yielded increasing evidence in terms of demography, social organization, and long-term territorial stability for the presence of more complex communities based primarily in highly productive estuarine and lagoon environments (DeBlasis et al. 1998, 2007; Gaspar et al. 2008). Zooarchaeological studies (Figuti and Klokler 1996; Klokler 2008) and isotopic analyses of human bone (Colonese et al. 2014) have shown that the diet of these groups relied predominantly on fishing, supplanting the deep-rooted idea of a simple nomadic shellfish-gathering economy. Indeed, bone artifacts from sambaquis are compatible with net and hook fishing technologies (Figuti and Klokler 1996). Anthracological analysis of sambaquis on the Río de Janeiro coast by Scheel-Ybert (2001) allowed for the first time the documentation of the consumption of monocotyledon tubers (Dioscorea sp., Typha sp., Cyperaceae), which along with the presence of palm fruit shells and seeds attest to the importance of plants in the diet of Sambaqui people. Evidence for the use of vegetable food (Boyadjian 2012; Scheel-Ybert 2013) is also reinforced by a variety of stone grinding tools and mortars found in sambaquis. Skeletal studies reveal evidence for canoeing and diving, a lifestyle linked to aquatic environments (e.g., Okumura and Eggers 2005).

Collectively, the evidence gathered so far suggests that Sambaqui society of the southern shores evolved for several millennia during the mid-Holocene and more 
recently (between 5000 and 2000 cal yr BP), with a considerable demographic expansion occurring without visible changes in social organization patterns. Social and economic complexification seems to have led to the emergence of a rather heterarchical social structure, with no particular evidence for social hierarchy. Further research will clarify to what extent these long-standing cultural patterns were widespread and whether there are subtle social changes that are still unseen in this long sequence.

\section{Pantanal}

Regional studies of settlement patterns in the Pantanal show that mounds seldom occur in isolation. They are generally found in clusters forming a line along the margins of streams and rivers, and forming circular to semicircular arrangements along the perimeter of lagoons; they also occur in hundreds in the flooded marshes, creating forest islands. A visual inspection of the distribution map of Córrego das Pedras (Schmitz et al. 1998, p. 81) reveals how these sites exhibit mound clusters of varied spatial arrangements: this surely deserves further exploration and detailed topographical mapping. Mounds are generally elliptic or elongated in plan; they exhibit diameters of 20-100 m and heights of 1-3 m. Schmitz et al. (1998) observed that the majority of mounds are located in places where today's floods do not cover the marshes more than $1.5 \mathrm{~m}$; they concluded that the Pantanal pre-Columbian people took advantage of topographically higher locations like river levees to construct mounds, similar to the wetlands of the Paraná Delta (Bonomo et al. 2011a) and southeastern Uruguay (Iriarte 2006a).

Based on the seasonality of resources, the location of sites in the landscape, the thickness of archaeological layers, relative density of artifacts, and the composition of the faunal assemblages, Schmitz et al. (1998, 2009) have suggested that the Pantanal populations were highly mobile canoe foragers who left behind two different types of archaeological sites. On the one hand, central sites have larger, more permanently occupied habitation areas. They are located in central and more stable margins of the larger lagoons and river dykes and contain thicker stratigraphic layers, a higher density of archaeological artifacts, primary and secondary burials, and necklace beads; the faunal assemblage is mainly composed of fish, mammals, and birds. On the other hand, short-term, temporary sites were are located in seasonally flooded marshes and likely related to seasonal occupations. Shellfish and crustaceans dominate the faunal assemblages of these sites; they lack fish, reptile, mammal, and bird bones.

Mound stratigraphy is a combination of natural and cultural processes. In general, the base of the mound has a natural silty clay layer followed by a crusty calcareous concretion layer, on top of which the cultural layers were deposited. The heterogeneous cultural strata contain layers of shellfish, fish, bird, and mammal bones as well as charcoal and ash lenses, which has led the excavators to interpret the mounds as habitation sites. Site MS-MA-50 represents a typical example of this recurrent stratigraphic sequence (Schmitz et al. 1998, p. 152, fig. 57).

The Pantanal offers rich and abundant resources for human populations. Wetlands encompassing water bodies and adjacent wet prairies and marshes 
contain a great variety of fish resources (Siluriformes, Scianidae, Hoplias sp., Serrasalminae, among others), alligator (Caiman yacare), turtles (Chelidae), shellfish (Pomacea, Marisa), capybaras (Hydrochoerus hydrochaeris), giant otters (Pteronura brasiliensis), and marsh deer (Blastocerus dichotomus) as well as a great abundance of birds. An important plant resource, wild rice (Oryza latifolia), grows in wetland margins; it must have provided another abundant seasonal resource for pre-Columbian populations, as it did for historic groups. Levees and the adjacent escarpment provided wood, tree, and palm fruits, among many other resources. However, these rich resources are highly seasonal and unevenly concentrated throughout the year. During the flooding season fish disperse into the wetland shallow waters while animals find refuge in the forest islands. Shellfish, from the genera Pomacea and Marisa, living in the roots of the water hyacinth aguape (Eichhornia crassipes), are easy to collect at this time of the year. This period also marks the beginning of the planting season. As the dry season starts, fish resources begin to concentrate in the larger lagoons; the fruits of gravatá (Bromelia balansae), bocaiúva (Acrocomia sclerocarpa), amendoim-do-bugre (Sterculia apetata), acuri (Attalea phalerata), and other palm and fruit trees are ripe; and canoe travel is possible only in large lagoons and river channels. As the dry season comes to an end, wild rice and cultivars, such as maize, are ready to collect and harvest. Today, Guató indigenous populations plant squash (Cucurbita sp.), cotton (Gossypium sp.), sweet potato (Ipomoea batatas), yams (Dioscorea trifida), tobacco (Nicotiana tabacum), manioc (Manihot esculenta), maize (Zea mays), and bananas (Musa spp.) as well as managing the acuri palm on the top of habitation mounds (De Oliveira 2000).

\section{Southern Proto-Jê}

Recent research shows that the southern Brazilian highlands were a highly structured landscape that revolved around funerary/ceremonial mound and causewayed enclosure complexes, usually located on hilltops or ridges commanding wide views. This distinctive range of monuments started to proliferate in the first half of the second millennium AD. Although recognized by early researchers (Ribeiro 1991; Rohr 1971), mound and enclosure complexes in the southern Brazilian highlands were not subject to intensive study. Locally called danceiros (dance grounds) in Brazil, they are characterized by circular, elliptical, rectangular, and keyhole-shaped earthworks whose rims are 30-80 cm tall, 3-6 m wide, and 20-180 $\mathrm{m}$ in diameter. They may exhibit or lack mounds and associated ringlets. Mounds are generally circular but can be rectangular platforms (e.g., SC-AG-12; DeMasi 2009); isolated large flat-top platforms have been documented around São José do Cerrito (Schmitz et al. 2013a), Lages, and Campo Belo do Sul localities (Fig. 6A).

In some regions, such as in El Dorado, Pinhal da Serra, Anita Garibaldi, and Campos Novos, mound and enclosure complexes occur together in groups, usually on the top of prominent hills that today exhibit wide view-sheds; several are positioned in relation to localized natural features such as rock outcrops that mark the highest spot of these hills (Iriarte et al. 2013; Saldanha 2008). However, these 

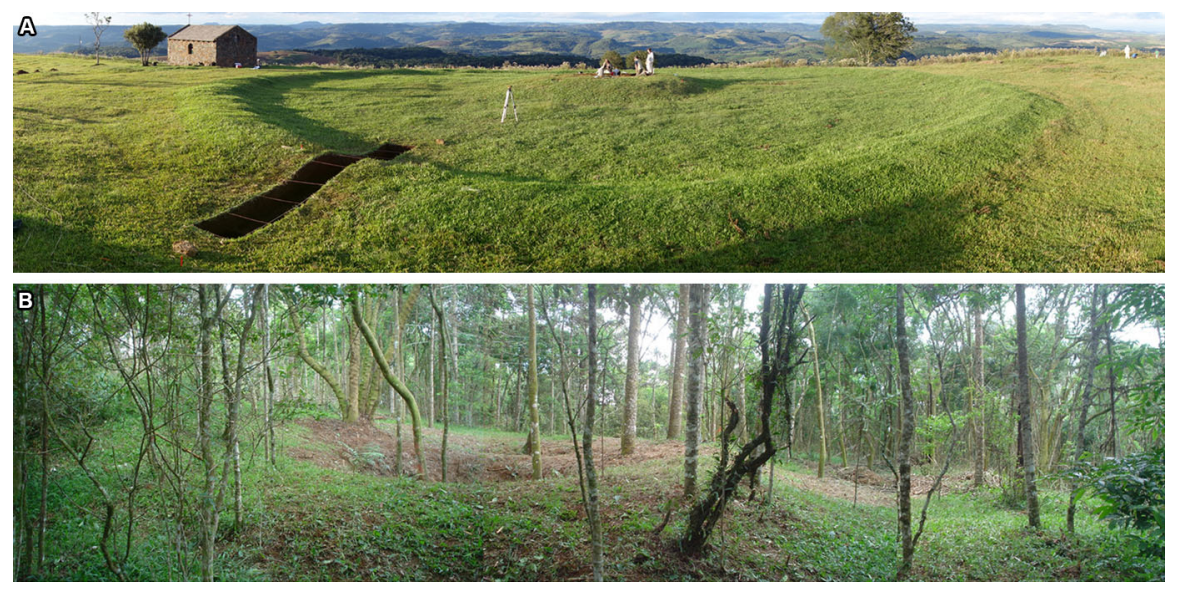

Fig. 6 Examples of Southern Proto-Jê earthworks: A, panoramic view of Abreu and Garcia mound complex showing circular bank (forefront), central mound (middle), and, wide viewshed; B, Houses 4 and 5 from the SC-CL-43 pit house village (Schmitz et al. 2010) showing the artificial low terrace around the houses on their downhill side.

funerary structures also can be found in lower positions in the landscape, such as in the Urubici region (Corteletti 2012; Corteletti et al. 2015, p. 47, fig. 1).

Detailed topographical survey of complete plateaus and ridges has allowed a number of novel insights on the development of these site formations, revealing the complexity of sites through the number of alignments between different site types. For example, on the Avelino plateau in Pinhal da Serra (Iriarte et al. 2013), one linear arrangement at the site consists of three earthworks focused on the central mound of each mortuary earthwork (Fig. 7). A key nodal point in these alignments is a solitary pit house that forms the central point of three of the six identified alignments; it potentially identifies this as one of the most important points on the hill. Isolated pit houses associated with mound and enclosure complexes also have been documented at the Chico Carneiro site in Pinhal da Serra and at the Abreu and Garcia site (Campo Belo do Sul), where a linear alignment with the central mounds at the site has been identified. Possible interpretations are that these structures were utilized as part of ritual or ceremonial activity on the hill or that they housed a key person within that activity sequence.

Mound and enclosure complexes appear to be divided into two size categories, which probably relate to different uses of the structures (DeMasi 2009; De Souza and Copé 2011; Rohr 1971). Smaller rings, with a diameter of 10-40 m, are far more numerous; they are generally arranged in pairs, exhibit low and narrow rims, and most of them contain a shallow central mound or a pair of mounds. Smaller structures show dual architecture, a general southwest-northeast alignment, with larger structures located in the western section; these latter are always located in a slightly topographically higher position than the smaller structure (see Iriarte et al. 2013).

Larger rings, 70-180 m diameter, are fewer and exhibit higher, wider, and easily visible rims up to $1 \mathrm{~m}$ tall. Some of the large rings, like the one we have been 


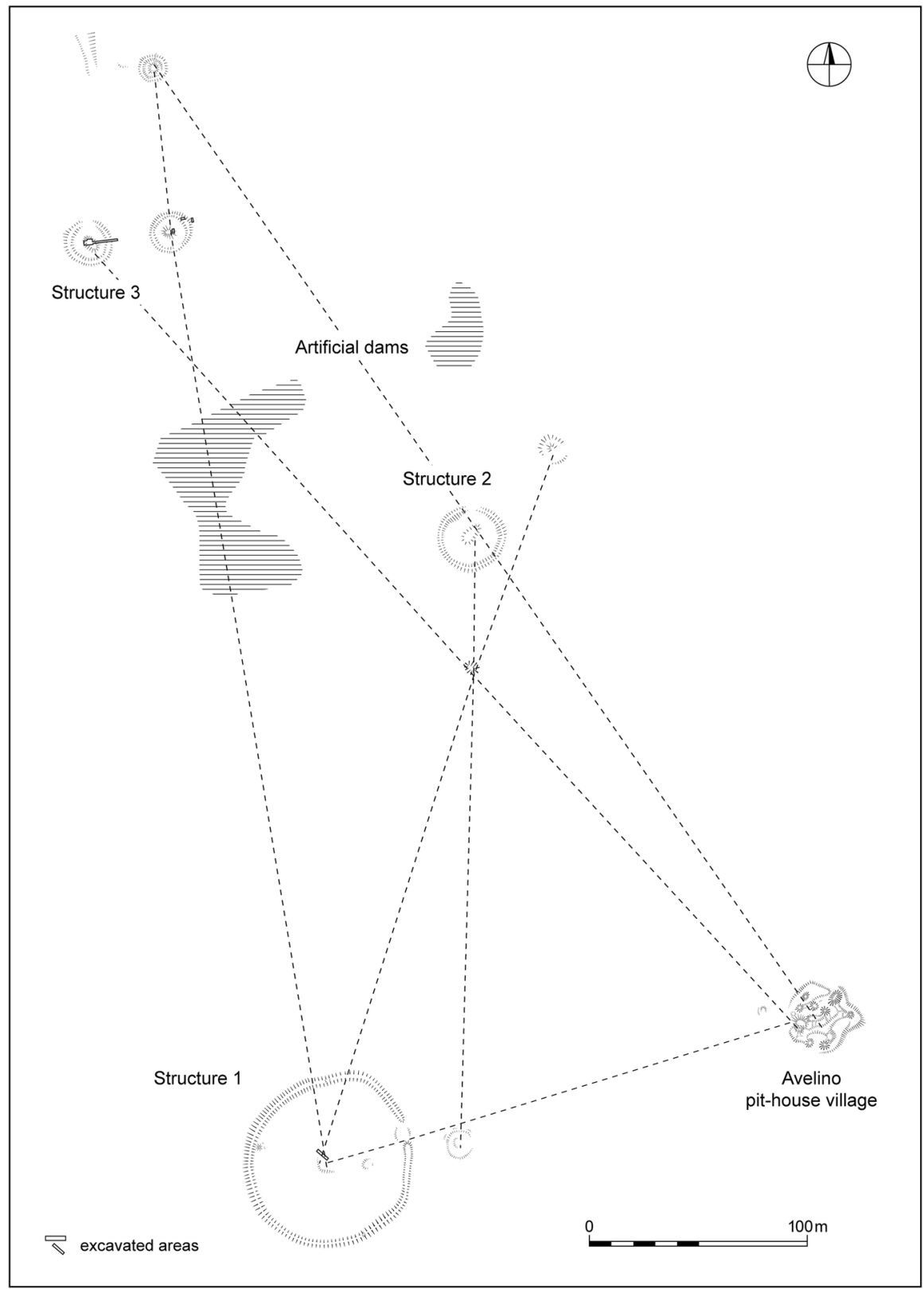

Fig. 7 The Avelino plateau topographical map showing linear arrangement of earthworks.

investigating in El Dorado, Misiones, Argentina (Iriarte et al. 2008a, 2010), or site SC-CL-37 in Santa Catarina (Reis 2007) are more complex than a simple circle layout and include entry avenues and associated attached ringlets (Iriarte et al. 2010, p. 28, fig. 2). 
Saldanha $(2005,2008)$ interpreted the small mound and enclosure complexes as likely village cemeteries. Following Adler and Wilshusen (1990), De Souza and Copé (2010) interpret small-paired mound and enclosure complexes as low-level integrative facilities built and visited by the inhabitants of nearby pit house villages. At these sites, the village inhabitants interred secondary inhumations and participated in collective funerary rites, reinforcing community ties. By contrast, large mound and enclosure complexes are interpreted as high-level social interaction facilities, whose construction involved the mobilization of labor from different communities dispersed across the region. More recently, Iriarte et al. (2013), drawing on the complementary asymmetry of historic Kaingang moieties, have suggested that the ritual separation of space in Southern Proto-Jê small-paired funerary structures, characterized by a larger mound and enclosure complex on the west side, may represent this dual ranked opposition.

Data from mound and enclosure complexes have provided one of the best avenues to discuss the complexity of the Southern Proto-Jê groups. For example, the SC-AG-12 mound complex consists of a pair of rings, Circle I and II, $30 \mathrm{~m}$ and $60 \mathrm{~m}$ in diameter, respectively (DeMasi 2006, 2009). The central mound of Circle I contains the cremated burial of an adult and an infant, and the central mound of Circle II contains six collective cremated burials. These cremated burials are accompanied by offerings including cups, food vessels, lip plugs, and ceramic figurines. In Circle I, in the area between the mound and the embankment, DeMasi (2006, 2009) excavated discrete stone clusters arranged in a crescent and facing the central mound, similar to the ones unearthed by Iriarte et al. $(2008 \mathrm{a}, 2010)$ at the base of rim at the PM01 site in El Dorado Misiones. DeMasi (2009) argues that the two individuals, an adult and an infant, buried in the mound of the larger ring located on the western side of the site, had a higher social status than the six individuals buried collectively in the smaller ring of this site.

The excavation of such burial mounds and the analysis of the cremated human remains within them also has begun to reveal a diversity of funerary practices, including the cremation and burial of single or multiple individuals within pyres and the subsequent redeposition of cremated bone (Müller and Mendonça de Souza 2011; Ulguim 2015). These analyses show that the treatment of the dead comprised several different stages including, but not limited to, the cremation of human remains in funerary pyres. Remnants of funerary pyres have been found at the base of the mounds, notably the Avelino site, Structure 3A (DeMasi 2009; De Souza and Copé 2010) and the Anita Garibaldi sites (SC-AG-12, SC-AG-98-Structure 2) (Müller and Mendonça de Souza 2011). Redeposition of burned bone in "cremated deposits" is also common, both in small pits as well as on mound floors (Thompson and Ulguim, in press). Sometimes these practices are present within the same mound. At Pinhal da Serra, excavations at the central mound of Avelino Structure 3A show that it was built over the remains of a funerary pyre containing burned bone. In the same mound, in a separate context, a cremated deposit was uncovered, where the body had been cremated in another locality; the remains had been gleaned from the pyre and then collected, possibly in a basket, transported, and deposited in a pit that was later covered with earth, forming a mound (De Souza and Copé 2010, p. 111, figs. 5, 6; Ulguim 2015). In addition, patches of burnt earth with 
a few charcoal fragments have been identified on mounds, suggesting that these could be the pyre bases and ash beds of pyres where all the burned bone was gleaned and redeposited at another mound, as at Posto Fiscal and SC-AG-12 mounds (DeMasi 2009; Iriarte et al. 2013). Finds of small ceramic cups are characteristically associated with the interments and possibly indicate food offerings. The fragmented nature of the burned bones recovered in excavations makes it difficult to identify the age and sex of the deceased, but the type of fractures on bones suggest that bodies were cremated with soft tissues and that fire temperatures may have exceeded $650{ }^{\circ} \mathrm{C}$ (Müller and Mendonça de Souza 2011). At the burial cut feature of Avelino Structure 3A, aging evidence from the unfused distal tibial epiphysis indicates a probable subadult of 14-20 years old. At SC-AG-108 Enclosure 2, evidence for dental eruption indicates an age of greater than 21 years (Ulguim 2015, p. 202).

Other interesting features at mound and enclosure complexes are the assemblages of stone clusters. At site PM01 in El Dorado Misiones, eight stone clusters dating to circa AD 1250-1270 have been unearthed on the base of the western sector of the larger ring of the site (Iriarte et al. 2010, p. 31, fig. 6); they have been interpreted as earth ovens similar to the ones used during historic times (Paula 1924). Phytolith analysis from charred residues of four ceramic sherds associated with these stone clusters documents the presence of maize cob, suggesting these ceramics were used to drink maize-based beverages. Iriarte et al. (2008a, 2010) argue that the vast plaza area of Circle I at site PM01, the accumulated earth ovens, and their associated ceramics indicate that large numbers of participants came together regularly at this notable ritual structure to feast on meat delicacies and maize beverages as part of postburial funerary practices. Another collection of earth ovens forming a crescentshaped spatial arrangement has been discovered in the sector between the rim and the central mound at the SC-AG-12 complex (DeMasi 2009). Single stone clusters also have been documented in mound floors at the Posto Fiscal site (Iriarte et al. 2013), again showing that these cooking structures were a common feature of mortuary sites and likely were associated with ritual feasting.

Finally, we also are beginning to understand the construction sequence of mound and enclosure sites and their architectural developments over time. Overall, excavated mounds from funerary structures associated with the Southern Proto-Jê groups are showing complex and diverse histories, ranging from the building of mounds as a single construction episode, as at the PR-UB-04 (Ubiratã) site (Chmyz and Sauner 1971), to the interments of several individuals in different episodes, as at the SC-AG-12 site (DeMasi, 2009). Detailed topographical survey and excavations at keyhole-shaped earthworks have revealed their construction history, showing a move from circular to rectilinear architectural shapes. For example, a rectangular annex was added to circular enclosures at the Reco and Posto Fiscal sites (Iriarte et al. 2013, p. 88, fig. 11), representing a movement toward more complex and diverse forms of architecture.

One of the most interesting aspects of the research on Southern Proto-Jê mound and enclosure complexes is that they reveal a clear connection between the archaeological record and ethnography. In fact, the southern Brazilian highlands are one of the few regions in the world where mortuary rituals associated with mound building are recorded in the European accounts of the 17th-19th centuries. 
Ethnographers subsequently investigated the Southern Jê groups during the 20th century (e.g., Baldus 1937; Becker 1976; Crépeau 1994; Henry 1964; Maniser 1930; Métraux 1946; Paula 1924; Veiga 2006). These groups exhibit dual social organization characterized by exogamic, patrilineal moieties. For the Kaingang, the moieties are complementary and also asymmetrical; the archaeological and ethnohistoric records suggest the presence of sizable, regionally organized, hierarchical societies (e.g., Crépeau 1994; Fernandes 2000). Importantly, funerary and postfunerary rituals are reported to be their single most important ceremony, when the entire group gathered together. These events included the burial of important chiefs, secondary burials, the inheritance of the chiefly office by the eldest son of the deceased chief, initiation rites, name-giving ceremonies, performance and recreation of the cosmogony myth, and feasting (e.g., Iriarte et al. 2008a, 2013; Maniser 1930; Métraux 1946; Silva 2001; Veiga 2006). The mound and enclosure complexes from the first half of the second millennium AD and the circumstances in which they arose are very different from the ones reported during the 17th-20th centuries. As we show below, there are many subjacent structures associated with the asymmetrical dual organization of these societies, and with the spatial segregation of ritual space and the alignment of burial mound and enclosures, that have endured during the historic times (see Iriarte et al. 2013). The connection also is exemplified at the Avencal rock art site in Urubici, which exhibits masks and faces with facial painting that could be related to Kaingang moieties. While some exhibit slim, tall, and open signs like the Kame moiety, others are characterized by circular, low, and closed motifs like the Kainru moiety (Riris and Corteletti 2015; Silva 2001).

Community patterns also are beginning to play an important role in understanding the nature of settlement patterns in the region. In the southern Brazilian highlands, clusters of pit houses or pit house villages of the Southern Proto-Jê groups are beginning to be seen in a new light. In general, detailed mapping of pit house clusters is rather limited, often focusing on the simple count of the overall number of individual pit house earthworks and their respective sizes, with an emphasis on the relevance of the largest examples. However, detailed topographical mapping, tailored to reveal community patterns, has recently led to reinterpretation of these sites. In the pit house villages of Pinhal da Serra-Avelino, Leopoldo, and Ari-we documented how pit houses are linked by a series of defined trackways, indicating carefully controlled directions of movement (Iriarte et al. 2013; figs. 7, 9, 14). The settlements are defined by artificial low terraces on downhill slopes (see also Saldanha 2005) (Fig. 6B). It is possible that these outer enclosure terraces may have formed part of a defensive rampart, especially if crowned by a timber palisade. As new large pit house villages are beginning to be mapped in their entirety, new spatial patterns are becoming apparent. At the São José do Cerrito locality, site Rincão dos Albinos exhibits 107 pit houses in two groups of 39 and 68 subterranean structures (Schmitz et al. 2013b). The larger group of houses is organized in discrete clusters and accompanied by a cluster of 10 mounds. In particular, small clusters of houses have a linear, u-shape, or semicircular layout, in one case surrounding a large mound (Schmitz et al. 2013b, p. 79, fig. 8). 
Oversized pit houses also are worthy of notice. These structures have diameters up to $20 \mathrm{~m}$ and, in one case, over $25 \mathrm{~m}$; depths may reach $7 \mathrm{~m}$ (Copé 2006; Reis 2007; Schmitz et al. 2010, 2013a). Although they may be isolated, oversized pit houses also may form part of clusters where they are surrounded by smaller pits; they are often are accompanied by large mounds (Copé 2006; Kern et al. 1989; Schmitz et al. 1988). It is not yet clear whether these structures represent habitations of extended families, high-status individuals, or communal facilities similar to men's houses and kivas. Some appear to have been regularly kept clean, with high densities of ceramics deposited in adjacent midden refuse areas outside the house (Schmitz et al. 2002); others revealed semicircles of hearths and associated activity areas around the center, suggestive of many nuclear families or different groups in a gathering place (Copé 2006). The large scale of these structures and the labor organization and effort necessary for their construction marks them apart from the other domestic sites. Site SC-CL-52 in São José do Cerrito consists of a 20-mdiameter, 7-m-deep pit house that was built on an artificial 2-m-high terrace. The site also exhibits a 2-m large platform mound in its surroundings (Beber 2013; Reis 2007; Schmitz et al. 2010, 2013a, b).

The application of microfossil botanical techniques also is changing our view of the diet of these groups and illuminating particular aspects of ritual behavior carried out in mound and enclosure complexes. Recent combined phytolith and starch grains residue analysis on ceramic fragments from two cooking structures at the Bonin site in Urubici has documented for the first time the consumption of manioc (Manihot esculenta Crantz), beans (Phaseolus sp.), and possibly yams (Dioscorea sp.), in addition to maize (Zea mays L.) and squash (Cucurbita sp.) (Corteletti et al. 2015). These results confirm that Southern Proto-Jê subsistence was based on a variety of plant foods and that the people had practiced food production for more than a century before the European Conquest. These data also call into question long-held models hypothesizing that Southern Proto-Jê people were highly mobile. Alternatively, it suggests that food production may have allowed populations to settle in the southern Brazilian highland plateau year-round, without the need for seasonal movements to the Atlantic forest escarpment and the Atlantic coastal environments to procure food (Corteletti et al. 2015). Similarly, phytolith analysis from charred residues of four ceramic sherds associated with earth ovens, uncovered at the base of the bank of the PM01 sites in El Dorado, suggests that these ceramics were used to drink maize-based beverages (Iriarte et al. 2008a).

In conclusion, the southern Brazilian highlands represent one of the most promising research areas in the Río de La Plata basin to investigate scenarios of social change concomitant with major transformations in the landscape. It is increasingly clear that the marked expansion of the resource-rich Araucaria forest at the turn of the second millennium AD was accompanied by novel social developments among the Southern Proto-Jê groups. The most evident of these is the rise of a new funerary tradition, represented by the mound and enclosure complexes, where a few cremated burials were commemorated by events of feasting. Parallel to that, aggregated well-planned villages emerged, with evidence of a long duration of use and sometimes with notable disparities in pit house size. Some villages include centrally placed oversized pit houses, with diameters over 
$20 \mathrm{~m}$, as well as mounded architecture. Management of the Araucaria forest, coupled with a more intense cultivation of domesticated plants, which also are present in the archaeobotanical record, might have provided the basis for the mortuary feasting events at mound and enclosure complexes, as well as leading to increased population density, territoriality, and disparities in house size. All of these processes potentially relate to the foundations of political complexity among the Southern Proto-Jê groups and to the formation of the regionally organized, hierarchical societies documented in the southern Brazilian highlands during the historical period.

\section{The Goya-Malabrigo Archaeological Entity}

Recent systematic survey in the Paraná Delta has documented 55 archaeological sites -50 on islands and only five on the adjacent grassland plains. Settlements are dispersed in the region. Mounds usually occur isolated, but they may form groups of two or three mounds. In some cases, like at Tres Cerros, three mounds show a linear alignment along the edge of a stream. Most mounds are oval in shape and may exhibit burrowing pits in their vicinity (Bonomo et al. 2011a, p. 309, fig. 6). Isolated mounds tend to be slightly larger (58 $\mathrm{m}$ max diameter) and higher (1.3 $\mathrm{m} \mathrm{max} \mathrm{high)}$ than mounds that appear in groups (49 $\mathrm{m}$ max diameter, $1 \mathrm{~m}$ max high). Mounds are usually located on the confluence of two tributaries, and the majority of mounds were built on higher topographical locations, mainly along levees and sand bars.

Similar to regions of the La Plata basin, the discussion about the natural (Frenguelli and Aparicio 1923) versus anthropic (Torres 1911) nature of mounds has been a subject of debate since the start of archaeological investigations in the region. More recently, Campos (2003) has reasonably argued that these earthen structures are artificial constructions emplaced on naturally elevated locations in the landscape such as river levees.

Detailed topography and multiproxy analysis of sediments at Tres Cerros and Cerro Tapera Vásquez showed that two anthropic processes contributed to the construction of these mounds: gradual accretion by the accumulation of domestic refuse and ad hoc loads of sediments added to elevate the living surface at top of the mound (Castiñeira et al. 2014; Politis et al. 2011). Excavations at the Los Tres Cerros site show that both domestic activities and burial activities were carried out at the site. Mound building at Tres Cerros started through the gradual accumulation of domestic refuse around 1000 cal yr BP; later on around 650-850 cal yr BP, the mound started to be used as a funerary area, with both primary and secondary burials, accompanied by capping episodes (Politis et al. 2011).

Mortuary practices of the Goya-Malabrigo archaeological entity are diverse, including primary and secondary burials; the latter includes bundles and dispersed elements, some of which show evidence of thermal alteration and the application of ochre on the bone surface (Scabuzzo et al. 2015).

Human skeletal remains from museum collections and excavations on the Paraná Delta with dates that go back 2,000 years have recently been analyzed (Mazza and Loponte 2012). Despite the fact that most of the interments cannot be clearly associated with an archaeological entity, due to the lack of precise contextual 
information and radiocarbon dates, the analysis nevertheless revealed interesting patterns to test with future research, including the recurrent presence of formal areas for the disposal of the dead, characterized by burial mounds, the predominance of secondary burials, and a preferred east-west orientation of primary burials. A clear differential treatment along sex and age lines also was demonstrated; adult males were interred in dorsal supine position, while women and children were positioned in ventral prone position (Mazza and Loponte 2012). The authors are wary of correlating this differential mortuary treatment to incipient social differentiation among these groups. They argue that sex differences in the treatment of the dead are common in hunter-gatherers where social differences are based on sex and age categories, and that these differences of sex and age also could be related to social categories of a different world view transmitted to the dead, or may mark horizontal rather than vertical social relationships (Mazza and Loponte 2012, pp. 17-18). The results of this study have been challenged by Politis and Bonomo (2015), who question the quality of the information marshaled by Mazza and Loponte (2012) and also refer to the detailed bioarchaeological analysis of 16 individuals from Tres Cerros Mound 1 by Scabuzzo et al. (2015), whose data contradict the patterns found by Mazza and Loponte (2012). This key issue clearly deserves further study.

Scabuzzo et al. (2015) argue for the complexity and importance given to secondary burials involving the intense manipulation of deceased bodies, including skeletonization, the selection of parts, painting with ochre, and the assembling of the bundle; the process also included the transfer of the dead to a socially connected, prominent, and highly visible mound site, showing the prominent role of ancestors in social reproduction.

The Goya-Malabrigo populations living in the Paraná Delta practiced a mixed economy mainly combining hunting of otter (Myocastor coypus), capybara (Hydrochoerus hydrocaeris), cuis (Cavia aperea), deer (Blastocerus dichotomus, Ozotoceros bezoarticus, Mazama sp.), and birds (Rhea sp., Podiceps major), with fishing (mainly Characiformes and Siluriformes), collecting freshwater shellfish (Diplodon sp., Hyriidae) and wild legumes like algarrobo (Prosopis sp.), and the cultivation of crops (Bonomo et al. 2011b). Recent application of phytolith and starch grain analyses from ceramic sherds and grinding tools, from six archaeological sites in the region dating around AD 1300-1490, has provided evidence for the consumption of maize (Zea mays), possibly beans (Phaseolus vulgaris), and squash (Cucurbita sp.) (Bonomo et al. 2011a; Sánchez et al. 2013). Although the horticultural nature of the economy of these groups is regularly mentioned in historical accounts, the poor preservation of macrobotanical remains and the lack of systematic application of archaeobotanical recovery techniques have prevented the documentation of these crops in the archaeological record until now.

Politis et al. (2011) and Bonomo et al. (2011b) argue that the Goya-Malabrigo entity exhibits a certain degree of sociopolitical complexity. Based on the comparison of the Tres Cerros mound complex with other sites in the region, they contend that the construction of mound complexes like those in the Tres Cerros locality presupposes "some sort of consolidated leadership able to organize the communal work of moving sediments and erecting earthen structures" (Politis et al. 2011 , p. 86); that the occurrence of isolated mounds and also mound complexes 
consisting of two or three sites may represent a dual settlement hierarchy; and that the presence of entire vessels and large numbers of modeled zoomorphic ornamental figures in the highest part of the central mound at the Tres Cerros mound complex may indicate a hierarchical division of space as evidenced by the concentration of symbolic items at the site level. The authors also note the presence of prestige objects, exemplified by nonlocal copper, the existence of differential burials, and the fact that early historic accounts describe the presence of chiefs, confederations, and slavery (see Bonomo et al. 2011a, p. 325).

\section{Late Holocene Hunter-gatherers of the Lower Paraná}

Discussions of cultural complexity in the Lower Paraná have focused on the dynamics of complex hunter-gatherers. The archaeology of hunter-gatherers also has received renewed attention in this resource-rich region. A comparison of resources between the wetlands of the Paraná Delta and the adjacent grassland plains (Campos) by Loponte et al. (2002) has shown how wetland resources are generally less mobile and more clustered, denser, and also more predictable; they also exhibit a higher offering of plant resources than the grassland plains. This contrast has prompted the authors (Loponte et al. 2002, p. 112) to suggest that these favorable conditions would have allowed the development of complex huntergatherer adaptations in the region. However, they also note that the seasonal nature of resources in this area should be considered, in particular the consequences of winter floods that cause terrestrial fauna to disperse and fish to become less concentrated.

Detailed comparative taxonomic and taphonomic studies also are allowing researchers to understand the animal component and preferred prey in the diet of these complex hunter-gatherers of the Lower Paraná. These studies also allow researchers to distinguish between natural and cultural faunal assemblages, as well as to characterize the palaeoenvironments in the vicinity of sites. For example, the analysis of fish remains at the La Bellaca site in the Paraná Delta, dated to circa 970-600 cal yr BP, shows that catfish (Siluriformes) and in particular granulated catfish (Pterodoras granulosus) dominate the archaeofaunal assemblage, along with Pampas deer (Ozotoceros bezoarticus), marsh deer (Blastocerus dichotomus), coypo (Myocastor coypus), and cuis (Cavia aperea) (Acosta et al. 2007). This latter rodent also was extensively exploited between 1700 and 700 BP (Acosta and Pafundi, 2005). As in southeastern Uruguay, domestic dogs also occur in these huntergatherer contexts (Acosta et al. 2011). The study of muroid rodents at La Bellaca and Las Vizcacheras in contexts dated 1000-600 cal yr BP shows a dominance of the web-footed marsh rat (Holochilus brasiliensis) along with other akodontines, indicating that the environment surrounding these sites was characterized by marshes and wetland prairies similar to the present landscape of the area (Teta et al. 2004). 


\section{Tupiguarani}

The rapid expansion of the Tupiguarani from Amazonia throughout most of the La Plata basin has always drawn the attention of researchers. Since the seminal work of Brochado (1984), all authors agree that the Tupiguarani advance throughout the South American lowlands represents a process of expansion rather than a migration in the strict sense; new daughter villages branched out from overpopulated old ones but maintained interaction and social ties with them in such a way that old territories were never abandoned. This process resulted in an expanding radius of village networks through gradual population waves (Bonomo et al. 2015; Brochado 1984; Milheira and DeBlasis 2014; Noelli 1993). Along these lines, Noelli (1993) proposes that the initial Tupiguarani advance was restricted to the major forested river floodplains. It was only after the consolidation of their territories and associated managed forest areas in these preferred environments took place that the Tupiguarani started colonizing smaller tributaries with gallery forests. In general, this model has been recently confirmed by a recent review of Tupiguarani dates in the Río de La Plata basin (Bonomo et al. 2015). This process has been observed in more detail by Ribeiro (1991) in the Pardo River valley in Río Grande do Sul state. In this study, the earliest and larger sites occupied the fertile floodplain, whereas the later sites are smaller and located in higher elevation zones. Based on the dates available for southern Brazil, and the distances involved, Rogge (2005, p. 93) calculates an expansion rate of $0.8-1 \mathrm{~km}$ per year, which is similar to that of the Neolithic in Europe and tentatively associates with a wave-of-advance model (sensu Ammerman and Cavalli-Sforza 2014).

Although considerable attention has been paid to the chronology and routes of the Tupiguarani expansion, recent research is enlightening many other aspects of this archaeological culture, including our understanding of settlement patterns and exchange networks, management of the environment and subsistence economy, and the interpretation of ceramic motifs and ritual, among other aspects. Several authors have envisioned the typical Tupiguarani settlement pattern as consisting of concentric circles radiating out from the village (located close to a permanent water source) and extending into home gardens, slash-and-burn plots, the forest, and other villages linked by roads (Assis 1996; Milheira and DeBlasis 2014; Noelli 1993). Noelli (1993) proposes that the catchment area of a village or cluster of dispersed homesteads could reach a $50-\mathrm{km}$ radius.

The Pelotas region, western coast of the Lagoa dos Patos in Río Grande do Sul state, is characterized by pioneer coastal vegetation and wetlands around the lagoon and subtropical semideciduous forests in the hinterland away from the lagoon. In an in-depth study of Tupiguarani settlement patterns in the Pelotas region, Milheira (2008) defined distinct site types based on size, density, and artifact assemblage diversity. In the forested areas, appropriate for slash-and-burn agriculture, Tupiguarani settlements form clusters of large villages, whereas in the coastal area most sites consist of small temporary fishing camps dispersed around a single village. The regions, $30 \mathrm{~km}$ apart, were articulated by a network of raw material exchange, confirming the model of Noelli (1993) who predicted regional systems of up to $50 \mathrm{~km}$ for Tupiguarani sites. 
The study of community patterns among the Tupiguarani has benefitted from a wide range of rich historical accounts. Ethnographic and ethnohistoric data show that the Tupiguarani lived in large palisade villages composed of many extended family longhouses. Colonial sources and a few published site plans suggest the longhouses were dispersed around an open plaza that served as a funerary area. This pattern has been largely confirmed by archaeological sites that show several elongated patches of dark earth with abundant ceramics, interpreted as remnants of houses around clean central spaces (plazas) that may contain funerary urns (Noelli 1993).

Although a prevalent view in the past was that Tupiguarani sites were rather ephemeral, some key areas are starting to reveal long-term occupation. One example is the Araruama lagoon complex in Río de Janeiro state, where a high density of Tupiguarani sites has been recorded (Macario et al. 2009; Scheel-Ybert et al. 2008). In this area, the Morro Grande site has provided several dates spanning 3000 to $480 \mathrm{cal}$ yr BP. The long-term occupation of Morro Grande has parallels in other key areas of Tupiguarani presence, such as the upper Paraná and the middle Jacuí Rivers, where nearly 1,500 years of continuous Tupiguarani occupation has been attested (Bonomo et al. 2015; Noelli 1999/2000). A southern example is the site RS$\mathrm{T}-114$, a large settlement located in a small tributary of the Jacuí River, with at least 500 years of continuous occupation between the 14th and 18th centuries (Schneider 2014). The chronological sequence of this site corroborates the proposal of Noelli (1993) that the Tupiguarani expanded into the gallery forests of secondary rivers in higher topographical positions after they consolidated their territories along the large floodplain. These are better-studied regions where many dates are available; in fact, as argued by Corrêa (2014, pp. 199-200) and Macario et al. (2009), the lack of multiple dates for most Tupiguarani sites is what often leads to the false impression of short-term occupations.

War, motivated by frontier expansion or revenge, as well as the subsequent ritual anthropophagic feasts, had a large social significance as a means of status acquisition among the Tupiguarani (Milheira and DeBlasis 2014). Anthropophagic feasts are described in numerous colonial sources, and a state of endemic warfare and strong warrior ideology persisted among modern Tupiguarani groups (Fausto 2001; Viveiros de Castro 1992).

Recent stylistic analyses of Tupiguarani pottery have helped confirm the importance of past mortuary and anthropophagic rituals. Prous (2005, 2010) observes that elaborate polychrome painting was primarily associated with ritual contexts. Such painting is present on vessels for fermenting beverages used during anthropophagic feasts and on vessels possibly used for serving the sacrificed enemy's flesh. Prous argues that many of the geometrical designs on these vessels are stylized representations of human faces, bodies, bones, and entrails (Prous 2005, 2010). Similarly, the designs on the elaborate polychrome pottery in the funerary area of the Morro Grande site have been interpreted as stylized representations of skeletal or visceral patterns (Buarque 2010). Innovative anthracological analysis at the Morro Grande site also has shed light on Tupiguarani funerary ritual. The funerary area of the site consists of a series of hearths encircling an urn accompanied by elaborate polychrome pottery. For these funerary hearths, 
Beauclair et al. (2009) have documented a preference for bark as fuel, which is not the case with the hearths from domestic contexts. Hearths are known from historical records to have accompanied Tupiguarani burials, but this is the first time that the intentional selection of a specific fuel (bark) has been identified in the archaeological record. Beauclair et al. (2009) attribute this selection to a symbolic parallel with the use of specialized hearths for firing ceramics, where bark is known to have been a preferred fuel.

The analysis of stable carbon isotopes on Tupiguarani skeletal remains is providing fresh evidence for their subsistence economy. Historically recorded Tupiguarani were tropical horticulturalists practicing slash-and-burn agriculture. They slashed the forest with stone axes and managed old fallows (Brochado 1984; Noelli 1993). Nearly all the cultivated products were of tropical origin, including manioc (Manihot esculenta), peanuts (Arachis hypogea), beans (Phaseolus sp.), potato (Solanum tuberosum), yam (Dioscorea sp.), sweet potato (Ipomoea batatas), maize (Zea mays), and squash (Cucurbita spp.). Archaeobotanical research by Schneider et al. (in press) identified maize and Phaseolus sp. starch grains as well as the endocarps of jerivá (Syagrus romanzoffiana) and pinto (Butia capitata) palms from a dark earth patch at site RS-T-114 (Taquari Valley) dated 490-150 cal yr BP.

Recent research has shed light on past Tupiguarani diet: stable isotope analysis of four skeletons buried in Tupiguarani urns from the Paraná Delta revealed an enriched average $\delta 13 \mathrm{C}$ content $(-15.5 \pm 0.78 \%$ ) (Loponte and Acosta 2007, 2013). This contrasts with 33 skeletons from hunter-gatherer sites of the same region, which exhibited a depleted isotopic range $(-19.3 \pm 1.23 \%$ o). From the latter sample, four individuals belong to Goya-Malabrigo context. The depleted $\delta 13 \mathrm{C}$ from this small sample of individuals suggests that although maize is present in the archaeobotanical record of the Goya-Malabrigo archaeological entity (Bonomo et al. 2011a; Sánchez et al. 2013), it did not constitute a major staple of the diet. It should be remembered that all cultigens in the Americas, apart from maize, produce a C3 signature. Therefore, the categorization of individuals with a strong C3 signature as hunter-gatherers should be regarded with caution and complemented with systematic archaeobotanical analysis that includes plant microfossils. Maize pollen has been documented in the vicinity of Tupiguarani occupations, dated to around $1810 \mathrm{cal}$ yr. BP in São Francisco de Assis (Behling et al. 2005), and between 1239 and 580 cal yr BP at Morro Santana (Behling et al. 2007). Archaeofaunal analysis from the Arroyo Fredes site in the Paraná Delta, dated to 556-894 cal yr BP, shows a faunal assemblage dominated by catfish (Siluriformes) and Characiform fishes, capybara (Hydrochoerus hydrochaeris) and coypo (Myocastor coypus) rodents, and marsh deer (Blastocerus dichotomus) (Acosta and Mucciolo 2009).

\section{Changing Landscapes}

New paleoecological work carried out in the region has substantially expanded and refined our understanding of Middle and Late Holocene environments (Behling and Pillar 2007; Bracco et al. 2011; Gessert et al. 2011; Iriarte 2006b; Iriarte and 
Behling 2007; Ledru et al. 1998). These improved environmental reconstructions have in turn allowed archaeologists to explore human-environmental dynamics in more precise ways. As in other lowland South American regions, like Amazonia (Mayle and Iriarte 2014), the close integration of archaeology and paleoecology through the retrieval of sediment cores close to archaeological sites, in order to look for crops and evidence of anthropogenic perturbances, has proven fruitful (Gessert et al. 2011; Iriarte 2006b).

\section{Constructores de Cerritos}

The novel use of paleoecological techniques to answer anthropological questions is beginning to reveal the role that the changing climates of the mid-Holocene played in the history of the Cerritos. Similar to other regions of the world (Sandweiss et al. 1999), the mid-Holocene was characterized by significant climatic and ecological changes that triggered important cultural transformations. The combined pollen and phytolith records from the Los Ajos core (see Fig. 2) in the India Muerta wetlands indicate that the mid-Holocene between 7715 and $4500 \mathrm{cal}$ yr BP was a period of significant climate fluctuations marked by increasing aridity. At around $4500 \mathrm{cal}$ yr $\mathrm{BP}$, a maximum drying episode occurred, as evidenced by a massive spike of Amaranthaceae/Chenopodiaceae coupled with a sharp drop in wetland species. This episode caused a decrease in the surface water recharge to the inland wetlands and waterways, which resulted in the desiccation of grasslands. This led to diminishing returns from grasslands, deepening the resource gradient between wetlands and grasslands. Although reduced in extent, wetlands became attractive places for preColumbian populations, providing abundant and now more highly circumscribed plant and animal resources, as well as a stable source of water (Iriarte 2006b).

Comparative archaeological data from the Los Ajos mound complex indicate that during this period of increased dryness local populations did not disperse (e.g., disaggregate into smaller groups with increased mobility) or out-migrate to other regions, but opted instead to orient their settlement toward the upper freshwater wetlands, where they established more permanent communities. A series of major social and economic changes took place at that time during the preceramic mound period. Los Ajos people began to live in circular household-based communities, dividing sites into discrete domestic and public areas characterized by the placement of residential units around a central plaza area (Iriarte 2006a). The combined archaeological and paleoecological evidence suggests that increased sedentism was a response to local resource abundance in wetland areas in the face of regional resource scarcity caused by the drying trend of the mid-Holocene.

Bracco and his collaborators (Bracco et al. 2005, 2011) have produced a multiproxy reconstruction of the climate during the Middle and Late Holocene from Atlantic Coast lagoons; this is not in agreement, however, with the Los Ajos pollen record for the freshwater wetlands over $15 \mathrm{~m}$ above sea level. The gastropod and diatom records produced by Bracco et al. (2005) show that the Negra lagoon was a brackish water body between around 4000 and 2000 cal yr BP and a freshwater one between $2000 \mathrm{cal}$ yr BP and the present. The phytolith record shows a drier and colder climate before 2000 cal yr BP and a hotter and more humid climate after 
2000 cal yr BP. Bracco et al. $(2005,2011)$ have major issues with the phytolith climatic indexes; there also are questions regarding the coastal nature of their record and its relation to marine transgressions, the hiatus that these records exhibit between 3500 and $2600 \mathrm{cal} \mathrm{yr} \mathrm{BP}$, and the fact that the records disagree with most other high-resolution pollen records from the region (see Iriarte 2006b; Iriarte et al. 2008b, 2016).

Another crucial aspect of human-environment relationships in the southern sector of the Merin Lagoon basin is the sea-level fluctuations that took place during the Middle and Late Holocene. As sea levels receded during the Late Holocene, they opened new areas for colonization in the low areas close to today's larger lagoon margins. However, the exact dates for these fluctuations and their amplitude are subjects of debate. Current data by Martínez and Rojas (2013) indicate that present-day sea level was reached in Uruguay by around $6000 \mathrm{cal} \mathrm{yr} \mathrm{BP}$ and that there was a major marine high stand, attaining $3.75 \mathrm{~m}$ on average, at around 5000 cal yr BP. Bracco et al. (2014), however, contest these data. In southern Brazil, Angulo et al. (2006) claim that sea level has been above that of the present and has been gradually declining over the last 5000-5800 cal yr BP, with a maximum height of no more than $4 \mathrm{~m}$. Despite this controversy, a general pattern has emerged showing that the present sea level in the region was reached between 6000 and 5000 cal yr BP. The pattern also shows a marine high stand of 5-3 m above sea level around $5000 \mathrm{BP}$, which converted the lower sectors of Merin Lagoon basin closer to the Atlantic Ocean into salt lakes, as indicated by the gastropod record of the Negra Lagoon (Bracco et al. 2005). As sea levels dropped, we see a progressive colonization of the lower regions of the area by the Cerritos. Regardless of uncertainties over the timing and height of sea-level fluctuations, the archaeological chronologies from the lower San Miguel wetlands and Los Patos Lagoon clearly show the colonization of these lower regions after circa $2500 \mathrm{cal} \mathrm{yr}$ BP (Bracco et al. 2005; Iriarte 2003). Accordingly, the areas located below the marine terraces at $3 \mathrm{~m}$ and $5 \mathrm{~m}$ above sea level contain thinner preceramic mound occupations, and it is only when sea levels dropped significantly that these areas were occupied more intensively, as reflected in the well-developed ceramic mound component of CH2D01, CH1D01, Los Indios, and the Patos Lagoon sites. Conversely, the upper ( $15 \mathrm{~m}$ above sea level) freshwater wetlands of the region, such as the wetlands of India Muerta, were not directly affected by these midHolocene marine high stands, and their more favorable conditions promoted the aggregation of populations along the restricted and limited resource-rich areas. The populations later expanded, filling the lower areas of the basin as they emerged.

Similarly, the low areas of the Pantanal wetlands also began to be intensively occupied by $5000 \mathrm{cal}$ yr BP. The integration of new paleoecological work (Whitney et al. 2011) with the archaeology of the region undoubtedly holds the key to an exciting study of human-environment relationships.

\section{Sambaquis}

The intensive survey, excavation, and radiocarbon dating program at the Santa Marta Lagoon have shown to great effect how sea-level changes shaped the 
adaptations and settlement patterns of Sambaqui groups in the Atlantic littoral zone. Although average sea-level change is a local-scale phenomenon, it is possible to see variations at a supraregional scale. In general, it is assumed that average sea level has risen dozens of meters on the Brazilian coast over the last 20,000 years, and that the current level was reached for the first time in the mid-Holocene, about 7000 years BP (Caruso Jr. 1995; Giannini 1993; Martin et al. 1979, 1986a, b; Martin and Suguio 1989; Suguio et al. 1985). Because most of the sambaquis on the Brazilian coast are more recent than the maximum transgressive of the Holocene, at around 5150 years BP, sites of some areas of the Brazilian coast may be older and therefore currently submerged (Kneip 2004; Prous 1992; Roosevelt 1992).

In the area around Santa Marta Lagoon, south of Santa Catarina state, Brazil, Angulo et al. (1999) built a model based on the age of fossil vermetid snails, Petaloconchus (Macrophragma) varians (d'Orbigny), reflecting variation in the average sea level and its position compared to the current average. Using variations in the sea-level curve, Kneip (2004) compared the position of several shell middens in the archaeological area of Santa Marta Lagoon to the sea-level curve predicted by the model. Kneip concluded that before 4200 cal yr BP, when the sea level was between 2.3 and $2.0 \mathrm{~m}$ above the current level, the lagoon likely attained its largest extent and sambaquis were therefore likely located at the margins of the lagoon. Later, around 4200 cal yr. BP, a marked regression in sea level began, and as a result sambaquis were apparently abandoned: there are no known dates between 4200 to 3200 cal years BP. It is only around $3200 \mathrm{cal} \mathrm{yr} \mathrm{BP}$ that the region witnessed renewed settlement, at the time of a new stabilization in sea level around $1 \mathrm{~m}$ above the current level. The main occupation of the Jabuticabeira 2 sambaqui occurred at that time (DeBlasis et al. 1998; Fish et al. 2000). The occupation of the sambaquis at the margin of the lagoon continued in sites like Caieiras, Congonhas 1, and Jabuticabeira 1, and began in others like Carniça 1, Congonhas 2, Mato Alto 1, and Morrote. Around $1500 \mathrm{cal} \mathrm{yr} \mathrm{BP,} \mathrm{the} \mathrm{average} \mathrm{sea} \mathrm{level} \mathrm{began} \mathrm{to} \mathrm{retreat} \mathrm{again,}$ reaching the current level 500 years ago and coinciding with the abandonment of major sites like Jabuticabeira and Morrote. Based on variation of the sea-level curve and the associated chronology from sambaquis, Kneip (2004) has suggested a circulation model linked to changes in the paleolagoon shoreline; as the sea retreated and advanced, the Sambaqui people relocated following the newly created shorelines to navigate this lagoonal environment. The occurrence of large numbers of sambaquis in other lagoonal areas farther north, on the coast of Santa Catarina (such as Babitonga Bay; Bandeira 2004) and in Paraná state (Guaratuba and Paranaguá Bays; Ramos 2014), suggests that this lifestyle spread along the coast of southeastern Brazil.

\section{Southern Proto-Jê}

Another example is the correlation of major cultural transformations and profound changes in the landscape that took place around AD 1000 in the southern Brazilian highlands, where an increase in habitation sites coupled with the appearance of mound and enclosure complexes and oversize pit houses is strongly associated with the advance of the Araucaria forest during the Late Holocene. At the end of the 
second millennium BP, the increasing availability of Araucaria seeds appears to have played a major role in the subsistence economy of these groups and could potentially have allowed them to settle the highlands more permanently and in greater densities than before. In addition to the collection of Araucaria nuts and other wild plants, hunting, and fishing, mounting evidence also points to an increasing use of domesticated plants by these populations (Corteletti et al. 2015). Current archaeological and palaeoecological research is being carried out to clarify these patterns. Overall, the close integration of archaeology and paleoecology in the Río de La Plata basin, as in other regions of lowland South America (Mayle and Iriarte 2014), will certainly pay off.

Archaeologists and palaeoecologists also are starting to investigate the different roles played by climate and humans in the changing landscapes of the region in the Late Holocene, as evidenced by pollen and charcoal records (Bitencourt and Kraspenhar 2006; Iriarte and Behling 2007). As mentioned above, habitation sites increased in the region around the turn of the first millennium $\mathrm{AD}$, along with the arrival of mortuary/ceremonial architecture and oversize pit houses in the highlands and the development of patches of dark anthropogenic soils in the Atlantic rainforest escarpment. Jê funerary patterns also began to appear along the coast. Significantly, these cultural changes are broadly contemporaneous with the abrupt expansion of Araucaria forest (Paraná pine), which according to some records, for example in Cambará do Sul (Behling et al. 2004; Behling and Pillar 2007), replaced highaltitude grasslands within about 100 years. The rapidity and timing of this process raises the possibility of an anthropogenic cause (Bitencourt and Kraspenhar 2006; dos Reis et al. 2014; Iriarte and Behling 2007). Previous palaeoecological work has generally attributed these abrupt changes as a response to increased precipitation (e.g., Behling and Pillar 2007). However, the human footprint in the expansion of the Paraná pine forest should be seriously considered. Paraná pine nuts were a major dietary staple of these pre-Columbian cultures; historically, regional chiefs had territorial control over Paraná pine forests, with collective feasts being held during times of food abundance when the nuts were ripening. One can speculate that this abundant and reliable resource may underlie the increase in archaeological sites and may have been integral to the emergence of social complexity. It is conceivable that the expansion of Paraná pine occurred not because of climate change but as a result of human activity that promoted the expansion of this economically important food resource.

It has not yet been possible to assess properly the relative influences of human versus climate change in driving this Araucaria forest expansion for several reasons. Most vegetation reconstructions have insufficient chronological resolution for this period; most cores have been retrieved from bogs/lakes at the highest spots of the highland plateau, far away from archaeological sites (Behling and Pillar 2007); and there are very few palaeo-vegetation reconstructions from the western ParanáUruguay basins and the Atlantic rainforest of the coastal escarpment. As a result, until now it was not possible to determine the environmental characteristics of either the local or regional Jê settlements or their development, vis-a-vis the transformation, and possibly anthropization of southern plateau environments. The potential manipulation of mixed Araucaria forest in the southern Brazilian highlands is not 
restricted to Araucaria; current studies are investigating the possible management of goiabeira-serrana (Acca sellowiana) (Santos et al. 2005), among other important economic fruits, by integrating botany, genetics, and archaeology. This is similar to work currently being undertaken in Amazonia (Clement et al. 2010; Shepard and Ramirez 2011) and certainly represents a prolific research perspective.

\section{Tupiguarani}

Despite the wealth of ethnohistoric accounts, Tupiguarani forest management only recently has become the subject of investigation, with the first palaeoenvironmental reconstruction of a Tupiguarani site being carried out in the Araruama Lagoon complex, a core area of Tupiguarani occupation in Río de Janeiro state (ScheelYbert et al. 2014). Anthracological analysis of charcoal from the Morro Grande site has demonstrated the permanence of Atlantic rainforest in the region between 3000 and $1600 \mathrm{cal}$ yr BP. However, the high proportion of taxa from early successional stages suggests a managed environment, and firewood was preferably collected from these secondary vegetation areas (Scheel-Ybert et al. 2014). An increase in the proportion of taxa from early succession stages suggests an opening of the vegetation around the site after about 1600 cal yr BP, probably due to human activity (Scheel-Ybert et al. 2014). In sum, the forest around Tupiguarani settlements was likely secondary forest resulting from managed old fallows in different states of succession (Scheel-Ybert et al. 2014). Ethnographic slash-andburn plots were usually rounded or elliptical in shape, ranging in size from 1 to 20 ha, although we need to take into account the profound transformation brought about by the Columbian Encounter-agricultural plots were possibly larger in preColumbian times (Noelli 1993).

\section{Expansions, Interaction Spheres, and Long-Distance Exchange Networks}

As with other major river systems in the Americas, from the Amazon (e.g., Hornborg 2005) to the Mississippi (e.g., Pauketat 2007), the La Plata basin was a highly contested landscape where multiple influences met, identities were negotiated, and traditions were born. Two of the major language families in South America, Tupiguarani and Jê, spread into the region starting around $3000 \mathrm{cal} \mathrm{yr}$ BP from the mosaic zones (sensu Diamond and Belwood 2003) of southwestern Amazonia and the central Brazilian cerrado (savannah), respectively (Bonomo et al. 2015; Noelli 1998; Urban 1992). To these, we can add the Goya-Malabrigo entity, whose Arawak origin would represent the expansion of another major Amazonian family into the southern latitudes starting around $2000 \mathrm{cal} \mathrm{yr} \mathrm{BP}$ (Politis and Bonomo 2012, 2015). However, the origin of the latter is still uncertain (Politis and Bonomo 2015).

Archaeologists in the region have now begun to explore these transcontinental interactions beyond the limitations of the culture history paradigm that dominated the archaeology of the Río de la Plata basin for so long. While recognizing the 
importance of past movements of people and ideas, archaeologists are now more interested in understanding how the diverse cultural backgrounds that converged in the basin led to different forms of interaction and local developments (e.g., Bonomo et al. 2015; DeBlasis et al. 2014; De Souza et al. 2016; Iriarte et al. 2008a; Politis and Bonomo 2012), beyond simply listing ceramic attributes and deriving them from waves of migrants. Recent work has focused on documenting the long-distance Tupiguarani exchange network (Loponte and Acosta 2013), tracing the spread of a new funerary architectural tradition among the Southern Proto-Jê after circa cal yr 1000 BP (Iriarte et al. 2008a, 2013), and the appearance of a shared ancestor cult of the Sambaqui societies along more than $600 \mathrm{~km}$ of the southeastern Atlantic Coast of Brazil (DeBlasis et al. 2007).

The development of frontiers as a consequence of the ethnic encounters that occurred in the Río de la Plata basin over the last 2,000 years is another topic of recent interest. Archaeologists working on this subject are interested in the material correlates of frontier zones; one of the most conspicuous expressions of rapid sociopolitical change is the spread of new forms of monumental public architecture, such as burial mounds, which create a new political landscape onto which institutions are projected (Bernardini 2005a, b; Dillehay 2007; Pauketat 2007; Pauketat and Loren 2005; Smith 2003). Due to their high visibility, monuments also are related to the assertive demarcation of territories (O'Shea and Milner 2002), especially from the perspective of evolutionary archaeologists that regard this phenomenon as a form of costly signaling-conspicuous displays to advertise a powerful message to outsiders (e.g., Boone 2000; Neiman 1997).

In southeastern South America, the role of the sambaquis as highly visible territorial foci for ancestor remembrance has been thoroughly studied (e.g., DeBlasis et al. 2007; Gaspar et al. 2008), but their relation to the newcomer Guarani and Jê groups during the Late Holocene still needs to be elucidated (DeBlasis et al. 2014). The same can be said of the funerary/domestic mounds of the Cerritos (López Mazz 2001) and the mound and enclosure complexes of the Southern ProtoJê (Iriarte et al. 2008a). For the latter, it is becoming increasingly clear that the earliest, largest, or more elaborate monuments emerged and proliferated during encounters with the Guarani and in places where the frontier between these two groups was permeable (De Souza et al. 2016; Iriarte et al. 2008a).

\section{Sambaquis}

Evidence for pan-regional ideological systems among the Sambaquis derives from splendid stone sculptures (known as zoolitos) found as grave goods in a few burials. Produced in clean and elegant fashion, these sculptures usually depict mammal or fish species very precisely, but geometric and anthropomorphic motifs also are found. The distribution of these sculptures over an extensive coastal area (Prous 1977) strongly suggests broad sharing of ideological symbols among the Sambaquis and Cerritos along the southern shores of Brazil and Uruguay (DeBlasis et al. 1998; Prous 1977). Furthermore, Calippo (2011) argues that Sambaquis society should be understood as a maritime community able to navigate long distances to reinforce 
kinship or exchange networks that included the sharing of deep-rooted symbolic animal entities such as the ones depicted in the zoolitos.

\section{Tupiguarani}

Ethnohistoric accounts bear witness to the long-distance networks established by the Tupiguarani in pre-Columbian times. Large confederacies of villages were recorded among the Tupiguarani in the historical period; these could include up to 40 allied villages under the influence of a prominent political or spiritual leader, and likely functioned as regional chiefdoms (Milheira and DeBlasis 2014; Noelli 1993). In the Paraná Delta, near modern Buenos Aires, Tupiguarani sites attest to long-range interactions, as evidenced by lithic raw materials obtained from sources 100-400 km distance (Loponte and Acosta 2013). Similar distances have been observed in southern Brazilian contexts and echo the confederations recorded in colonial times (Milheira 2008; Noelli 1993). Interestingly, Tupiguarani sites in the Paraná Delta contained metal objects, including an Andean bronze pendant, which Loponte and Acosta (2013) also attribute to long-distance networks of exchange.

The Tupiguarani also played a primordial role in integrating interaction spheres with local traditions. Although conflict with pre-established populations was postulated as a major consequence of Tupiguarani territorial expansion (Brochado 1984; Noelli 1993), in many areas other types of interaction were documented. Rogge (2005) argues that warfare and the creation of impermeable frontiers (perimeter defense) were important only during the initial stages of Tupiguarani expansion into the major river valleys. As population grew and people were pushed out of subtropical deciduous forest areas to less-favored environments (which were densely occupied by rival groups), such as the borders with Araucaria forest occupied by Southern Proto-Jê groups, or temperate grasslands by the Cerritos, this violent strategy became too risky and costly. Instead, later migration waves into these areas established a permeable social frontier. The circulation of objects, individuals, and information across the frontier would have facilitated access to various ecological niches by the Tupiguarani and previously established groups (Rogge 2005).

Archaeological evidence of such flux of people and information abounds. In the escarpment of the southern Brazilian highlands, in zones of transition between subtropical deciduous forests and the Araucaria forest, the Tupiguarani actively interacted with Southern Proto-Jê groups. This is evidenced by the presence of intrusive Tupiguarani ceramics, sometimes forming true enclaves and suggesting entire domestic units of Tupiguarani origin living within Southern Proto-Jê settlements (DeMasi and Artusi 1985; Ribeiro 1991). The interaction with the Cerritos seems to have been less intense, involving primarily a flux of objects and information but not of people; this is reflected in the abundant pottery with Tupiguarani stylistic influences found in the upper layers of mounds at zones of transition between temperate grasslands or wetlands and the subtropical deciduous forest (e.g., Brochado 1984; Cabrera et al. 2000; Schmitz et al. 1970). As observed by Rogge (2004), historically documented groups in this region such as the 
Arachané were probably descendants of Pampean populations who adopted the Tupiguarani language and way of life.

\section{Southern Proto-Jê}

The monumental funerary architecture of Southern Proto-Jê groups may be the best example of how new traditions were born out of the multiethnic interactions that took place during the Late Holocene. Although Southern Proto-Jê groups were established in the highlands for 2,000 years, it was only in the latter half of this period that they started building mound and enclosure complexes as a novel form of funerary architecture. By synthesizing the dates and locations of all known mound and enclosure complexes in the highlands, De Souza et al. (2016) has demonstrated that they emerged in a period when the Guarani groups started to advance toward the highlands, and that they proliferated only in areas where the local groups did not interact with the outsiders. De Souza et al. (2016) argue that the construction of chiefly burial mounds represented a form of smart advertising to keep outsiders out; they were a key element in the regional integration of Southern Proto-Jê groups, undertaken in order to resist the Guarani migrants. It is no coincidence that the largest and architecturally most elaborate mound and enclosure complex (PM01) is found precisely at the western edge of Southern Proto-Jê territory, where not only the Guarani but also the Goya-Malabrigo and, possibly, groups from Chaco were all juxtaposed. Iriarte et al. (2008a, pp. 958-959) suggest that the postburial gatherings and feasting that took place at such monuments were political events that promoted intervillage integration at a time of increased interethnic contact.

\section{Goya-Malabrigo Archaeological Entity}

During the last century several authors including Nordenskiöld (1930), Métraux (1934), Torres (1934), and Acosta y Lara (1955) proposed an Amazonian Arawak origin for the Goya-Malabrigo entity and their purported historical descendants: the Chana-Timbú. This debate has been renewed in the light of reexamination of historical sources and the collection of oral histories (Politis and Bonomo 2012). Similar to the Guarani, the Goya-Malabrigo archaeological entity is rather homogenous and entered the local contexts as an already formed entity around $2000 \mathrm{cal}$ yr BP. The origin of the Goya-Malabrigo entity is still uncertain, and there is debate over the extent to which it represents a foreign migration and ethnogenesis or else an adaptive process of local populations (Politis and Bonomo 2012, 2015). Based on the sum of calibrated probability diagrams encompassing the 53 radiocarbon dates available for the region and taking into consideration sampling, taphonomic, and archaeological visibility biases from this record, Politis and Bonomo (2015) suggest a north-south dispersion of the Goya-Malabrigo archaeological entity, starting with a few sites around 2000 cal. BP in the middle Paraná, a small increment of sites between 1800 and $1000 \mathrm{cal} \mathrm{BP}$, and the more dense/ stable occupation of the islands along the middle and lower Paraná River, as well as the lower Uruguay River, from 1000 cal BP until the arrival of the Europeans. 


\section{Final Considerations and Conclusions}

Several general trends emerge from our comparative analysis of the emergence of complexity in the Early Formative cultures of the Río de la Plata. Regardless of how complex these societies were, how permanent their settlements were, and how much they relied on cultigens (all important questions by themselves), what stands out is the existence of more diverse, autonomous, specific complex developments in an area previously thought of as marginal when compared with the cultural developments in the Andes or Mesoamerica (e.g., Steward 1946; Steward and Faron 1959). Furthermore, the apparent distinctiveness of these earthen architectural traditions and built landscapes in relation to other Andean (e.g., Dillehay 2011; Schwarz and Raymond 1996) and South American lowland groups (e.g., Cabral and Saldanha 2008; De Boer 1997; Heckenberger et al. 2008; Redmond and Spencer 2007; Schaan 2012; Siegel 1999) makes them an important contribution to the comparative study of the rise and dynamics of complex societies in lowland South America and in other locations where similar earthen architecture and funerary monuments have been documented (e.g., Bradley 1998; Carr and Case 2006; Mainfort and Sullivan 1999; Thompson and Worth 2011).

When compared with other regions of lowland South America and the Andes, current research in the Río de la Plata basin and its adjacent littoral zone show that this region was an early locus of population concentration and emergent complexity. A case in point is the unexpectedly early cultural sequences revealed in the various wetlands that pervade this broad region. For example, permanent circular mounded villages with a mixed economy first appeared by circa $4750 \mathrm{cal} \mathrm{yr} \mathrm{BP}$ in the wetlands of southeastern Uruguay (Iriarte 2006a; Iriarte et al. 2004), contemporary with the first corporate monumental architecture of the late preceramic period on the Peruvian coast (Burger 1995; Moseley 2001; Shady Solis et al. 2001). Mounded architecture has similar early dates in the Pantanal (Schmitz et al. 1998; Schmitz et al. 2009), and even earlier dates are found among the mound builders who settled along the southern Brazilian shores.

The interdisciplinary project in southeastern Uruguay showed that as in other regions of the world (Sandweiss et al. 1999), the mid-Holocene was characterized by significant climatic and ecological changes, and that these perturbations were associated with important cultural transitions that involved permanent mounded settlements situated within resource-rich, circumscribed wetlands. This work suggests that increased sedentism was a response to local resource abundance in wetland areas, in the face of regional resource scarcity produced by the drying trend of the mid-Holocene. Intriguingly, the low areas of the Pantanal wetlands also began to be intensively occupied around the same time by $5000 \mathrm{cal} \mathrm{yr}$ BP. The integration of new paleoecological work (Whitney et al. 2011) with the archaeology of the region certainly holds the key for further study of human-environment relationships. It is becoming clear that wetlands were key environments that provided critical loci for human occupation by offering important plant, animal, bird, and fish resources. Wetlands also provided greater stability; they reduced risk during periods of environmental change because they contained a stable supply of water, and as in 
other world regions, provided an ideal context for the adoption and intensification of agriculture (e.g., Pohl et al. 1996; Siemens 1999).

Later, around the turn of the second millennium BP, we also perceive a more intense occupation of wetland regions, as evidenced by a larger number of sites and new cultural traditions in the Pantanal, the Chago Santiagueño, Uruguay, and the lower Paraná River. These trends are paralleled by a more intense occupation of the seasonally flooded savannahs north of this region in the Llanos de Moxos, starting around AD 400 (Whitney et al. 2013).

The Christian era seems to be a critical period of increased population density and intensification of landscape transformation by local wetland groups, but it is also marked by the rapid expansion of influences from outside the La Plata basin. From the Amazon basin, Tupiguarani and Arawak groups disperse along the major riverine routes of the Paraguay, Paraná, and Uruguay Rivers and their tributaries, and from the savannahs of central Brazil the Jê peoples made their first incursions into the southern Brazilian highlands. All these groups became well established in the Río de La Plata basin at the turn of the first millennium AD. In locations where intensive fieldwork has been carried out, archaeological evidence indicates that by AD 1000 these populations were organized at a regional level, became more territorial, and adopted more intensive food-production practices. Among the Jê groups, it was at this period that monument construction reached its peak.

In addition, it has become clear that, like in most regions of South America, there is a large discrepancy between the complexity documented in the archaeological record and the profoundly transformed historical indigenous societies, which should prevent researchers from easy extrapolation of the social, economic, and political organization of historic groups to the past. However, where rich historical and ethnographic records exist, as with the Southern Proto-Jê, for example, we can clearly see how underlying structural principles materialized on monumental architecture have survived (Iriarte et al. 2013). Oral histories are also beginning to be incorporated, with enlightening results (Politis and Bonomo 2012).

Archaeologists in the region have moved away from simplistic diffusionist models and are beginning to appreciate how the role played by the Jê, Tupiguarani, and Arawak immigrants in the development and dynamics of groups already established in the region has not yet been properly assessed (e.g., Milheira and DeBlasis 2014; Politis and Bonomo 2012). It is now clear that the Tupiguarani established a long-distance exchange network that reached to the Andes (Loponte and Acosta 2013). We can track the spread of a new funerary architecture represented by earthen mounds and enclosures among the Southern Proto-Jê (Iriarte et al. 2008a, 2013) and speak about shared ancestor cult of the Sambaqui societies along the Atlantic Coast (DeBlasis et al. 2007). This means that we must begin to see the Río de La Plata basin as other large river systems of the Americas-a highly contested geographical enclave prone to the juxtaposition of identities, where novel sociopolitical arrangements emerged, ethnicities are congealed, and traditions were invented and projected onto the landscape (Bernardini 2005a, b, 2011; Pauketat 2001, 2007, 2010; Pauketat and Loren 2005; Sassaman 2005, 2010). The arrival of these external influences did not necessarily mark an abrupt rupture with the midHolocene cultures of the region. In the case of the Sambaquis, the arrival of 
Southern Jê influences seems to have been a complex process involving both population replacement in some areas and adoption of ceramics by local groups in others (DeBlasis et al. 2014; Okumura and Eggers 2005).

In addition, the systematic application of archaeobotanical techniques is revealing new trends. For a long time in the archaeology of the La Plata basin, the prevailing paradigm was that Amazonian Tupiguarani immigrants brought agriculture and cultigens with them during the Late Holocene (Schmitz 1991). It is hardly surprising that this interpretive framework fit comfortably with the long-held assumption that the region was inhabited by marginal hunter-gatherers (Meggers and Evans 1978; Steward and Faron 1959). The systematic application of paleoethnobotany recovery techniques is bringing to bear new data that counter the generally accepted view that cultigens and agriculture were brought by Tupiguarani immigrants around AD 1 into a region inhabited only by groups of foragers who were flexibly adapted to a diversity of environments (Rodríguez 1992; Schmitz 1991). For example, multidisciplinary investigations at the mound complex of Los Ajos, belonging to the Cerritos archaeological culture, found that cultigens were introduced and became integrated into local food economies much earlier than previously thought, shortly after 2200 BC (Iriarte 2006a; Iriarte et al. 2004).

As a result of decades of sustained systematic archaeological research coupled with new methodological advances, we can now begin to reconstruct regional settlement patterns in more detail in some regions. Intensive research in the southern Brazilian highlands is now revealing highly structured landscapes revolving around mortuary/ceremonial structures (Corteletti 2012; DeMasi 2009; Iriarte et al. 2013; Saldanha 2005). Research on the Los Ajos site in southeastern Uruguay showed that the site was a well-planned village incorporating public and domestic spaces. Similarly, maps of large pit house clusters such as at Rincão dos Albinos, consisting of 107 subterranean structures, show that small clusters within these larger sites exhibit recurrent linear, u-shaped, or semicircular arrangements surrounding large mounds (Schmitz et al. 2013b).

The construction sequence of mounds in the Pantanal, the Merin Lagoon basin, northeastern Uruguay, and the Paraná Delta shows an interesting commonality. Mounds in these regions appear to have started by the gradual accumulation of occupation refuse associated with their domestic use, to which capping episodes associated with a funerary use were later added. Similar to what we see at Los Ajos and other sites in southeastern Uruguay, mound building at Tres Cerros in the Paraná Delta started through the gradual accumulation of domestic refuse around 1000 cal yr BP. Later, around 850-650 cal yr BP the mound started to be used as a funerary area, and ad hoc cappings of sediments were added. Similarly, on the southern shores of the Atlantic Coast, settlement systems associated with shell mound-building cultures (or Sambaqui culture), previously thought to have been the remains of successive campsites from shifting groups of shellfish collectors, have revealed a much more complex scenario. Detailed chronology and site formation analyses have shown sedentary populations with diversified dietary patterns, active landscape management, and ceremonial mound building related to the cult of the ancestors, with strong territorial ties to the open and resourceful aquatic environment they lived in. 
Settlement patterns and mound construction histories also have shed light on different cultural trajectories. We find a similar investment in monumental construction and elaboration of burial rites coupled with a tendency towards territoriality and regional organization among both the Sambaquis and the Southern Proto-Jê. However, it appears that each of these traditions corresponds to very distinctive social formations, more heterarchical and egalitarian in the first case (DeBlasis et al. 2007) and more centralized and hierarchical in the latter (DeMasi 2009; Iriarte et al. 2008a).

The acknowledgment of the apparent distinctiveness of these earthen architectural traditions and built landscapes in relation to other Andean (e.g., Dillehay 2011; Schwarz and Scott Raymond 1996) and South American lowland groups (e.g., Cabral and Saldanha 2008; De Boer 1997; Heckenberger et al. 2008; Redmond and Spencer 2007; Schaan 2012; Siegel 1999) is by itself making an important contribution to the comparative study of the rise and dynamics of complex societies in lowland South America and elsewhere where similar earthen architecture and funerary monuments have been documented (e.g., Bradley 1998; Carr and Case 2006; Mainfort and Sullivan 1999; Thompson and Worth 2011).

This review of recent evidence also indicates that the trajectories toward increased sociopolitical complexity in the Río de la Plata basin flourished in very different environmental conditions, without showing a one-to-one relationship. In the mid-Holocene, aggregated villages represented by large and spatially complex mound sites emerged among the Cerritos during a dry period in circumscribed, resource-rich wetland environments (Iriarte 2006a, b). In contrast, in the more humid climate of the Late Holocene, the region witnessed the marked expansion of the resource-rich Araucaria forest, accompanied by novel social developments among the Southern Proto-Jê groups at the turn of the second millennium AD. The potential human management of the Araucaria forest, coupled with a more intense cultivation of recorded domesticated plants, might have provided the basis for the mortuary feasting events at mound and enclosure complexes, increased population density and territoriality, and the emergence of disparities in house size. All of these processes potentially relate to the foundations of political complexity among Southern Proto-Jê groups and to the formation of the regionally organized, hierarchical societies documented in the southern Brazilian highlands during the historical period.

Acknowledgments This paper was developed in the context of Arts and Humanities Research CouncilSão Paulo Research Foundation (AHRC-FAPESP) project "Jê Landscapes of Southern Brazil: Ecology, History and Power in a Transitional Landscape during the Late Holocene" awarded to Jose Iriarte, Paulo DeBlasis, and Francis Mayle. Jonas Gregorio De Souza was funded by Coordenação de Aperfeiçoamento de Pessoal de Nível Superior (CAPES) and Rafael Corteletti by the São Paulo Research Foundation (FAPESP). We thank Priscilla Ferreira Ulguim and the six anonymous reviewers for the helpful comments that helped improve the manuscript.

Open Access This article is distributed under the terms of the Creative Commons Attribution 4.0 International License (http://creativecommons.org/licenses/by/4.0/), which permits unrestricted use, distribution, and reproduction in any medium, provided you give appropriate credit to the original author(s) and the source, provide a link to the Creative Commons license, and indicate if changes were made. 


\section{References Cited}

Acosta, A., and Mucciolo, L. (2009). Zooarqueologia de los grupos de horticultores amazônicos no Rio Paraná Inferior: O caso do sítio Arroyo Fredes. Revista de Arqueologia SAB 22: 43-63.

Acosta, A., Loponte, D., and García Esponda, C. (2011). Primer registro de perro doméstico prehispánico (Canis familiaris) entre los grupos de cazadores recolectores del humedal del Paraná Inferior (Argentina). Revista de Antropología y Arqueología 13: 175-199.

Acosta, A., Loponte, D., and Musali, J. (2007). A Taphonomic approach to the ichthyoarchaeological assemblage of the La Bellaca Site 2, wetland of the lower Parana River, Pampean region (Argentina). In Gutierrez, M., Barrientos, G., Salemme, M., Miotti, L., and Mengoni Goñalons, G. (eds.), Taphonomy and Zooarchaeology in Argentina, BAR International Series 1601, Archaeopress, Oxford, pp. 71-88.

Acosta, A., and Pafundi, L. (2005). Zooarqueología y tafonomía de Cavia aperea en el humedal del Paraná inferior. Intersecciones en Antropología 6: 59-74.

Acosta y Lara, E. F. (1955). Los chaná-timbúes en la antigua Banda Oriental. Museo de Historia Natural de Montevideo 6: 1-27.

Adler, M. A., and Wilshusen, R. H. (1990). Large-scale integrative facilities in tribal societies: Crosscultural and southwestern US examples. World Archaeology 22: 133-146.

Almeida, F. O. (2013). A Tradição Polícroma no Alto Rio Madeira, Ph.D. dissertation, Museum of Archaeology and Ethnology, University of São Paulo, São Paulo.

Almeida, F. O., and Neves, E. (2015). Evidências arqueológicas para a origem dos Tupi-Guarani no leste da Amazônia. Mana 21: 499-525.

Aldenderfer, M. (1993). Ritual, hierarchy, and exchange in foraging societies. Journal of Anthropological Archaeology 12: 1-40.

Ambrosetti, J. B. (1893). Sobre una colección de alfarerías minuanes recogidas en la provincia de Entre Ríos. Boletín del Instituto Geográfico Argentino 14: 242-265.

Ammerman, A. J., and Cavalli-Sforza, L. L. (2014). The Neolithic Transition and the Genetics of Populations in Europe, Princeton University Press, Princeton, NJ.

Angulo, R.J., Giannini, P.C., Suguio, K., and Pessenda, L.C. (1999). Relative sea-level changes in the last 500 years in southern Brazil (Laguna-Imbituba region, Santa Catarina State) based on vermetid ${ }^{14} \mathrm{C}$ ages. Marine Geology 159: 323-339.

Angulo, R. J., Lessa, G. C., and Souza, M. C. d. (2006). A critical review of mid- to late-Holocene sealevel fluctuations on the eastern Brazilian coastline. Quaternary Science Reviews 25: 486-506.

Araújo, A. G. (2001). Teoria e método em arqueologia regional: um estudo de caso no alto paranapanema, estado de São Paulo, Ph.D. dissertation, Museum of Archaeology and Ethnology, University of São Paulo, São Paulo.

Araujo, A. G. (2007). A tradição cerâmica Itararé-Taquara: características, área de ocorrência e algumas hipóteses sobre a expansão dos grupos Jê no sudeste do Brasil. Revista de Arqueologia SAB 20: 9-38.

Arnold, J. E. (1996). Emergent Complexity: The Evolution of Intermediate Societies, International Monographs in Prehistory Vol. 9, University of Michigan Press, Ann Arbor.

Ashmore, W., and Knapp, A. B. (1999). Archaeologies of Landscape: Contemporary Perspectives, Wiley-Blackwell, Oxford.

Assis, V. S. (1996). Da espacialidade Tupinambá, Ph.D. dissertation, Department of Anthropology, Pontifícia Universidade Católica do Rio Grande do Sul, Porto Alegre.

Baker, W. (1996). Measuring social complexity and variation: A categorical imperative? In Arnold, J. E. (ed.), Emergent Complexity, International Monographs in Prehistory, Ann Arbor, MI, pp. 13-24.

Baldus, H. (1937). Ensaios de etnologia brasileira, Companhia Editorial Nacional, São Paulo.

Bandeira, D. (2004). Ceramistas pré-coloniais da Baía da Babitonga, SC - arqueologia e etnicidade, Ph.D. dissertation, Department of History, Universidade Estadual de Campinas, Campinas.

Bandeira, A. M. (2008). Ocupações humanas pré-históricas no litoral maranhense: um estudo arqueológico sobre o sambaqui do Bacanga na ilha de São Luís - Maranhão. M.A. thesis, Museum of Archaeology and Ethnology, University of São Paulo, São Paulo.

Barrett, J. C. (1996). The living, the dead and the ancestors: Neolithic and Early Bronze Age mortuary practices. In Preucel, R., and Hodder, I. (eds.), Contemporary Archaeology in Theory, Blackwell, London, pp. 394-412. 
Beauclair, M., Scheel-Ybert, R., Bianchini, G. F., and Buarque, A. (2009). Fire and ritual: Bark hearths in South-American Tupiguarani mortuary rites. Journal of Archaeological Science 36: 1409-1415.

Beber, M. V. (2005). O sistema do asentamento dos grupos ceramistas do planalto sul-brasilero: o caso da Tradição Taquara/Itararé. Documentos 10: 5-125.

Beber, M. V. (2013). Sítios arqueológicos do município de São José do Cerrito, SC: um panorama. Pesquisas Antropologia 70: 43-64.

Beck, A. (1972). A variação do conteúdo cultural dos sambaquis, litoral de Santa Catarina, Ph.D. dissertation, Department of Anthropology, University of São Paulo, São Paulo.

Becker, I. I. (1976). O Indio Kaingang no Rio Grande do Sul, Universidade do Vale do Rio dos Sinos, São Leopoldo.

Behling, H., Pillar, V. D., Müller, S. C., and Overbeck, G. E. (2007). Late-Holocene fire history in a forest-grassland mosaic in southern Brasil: Implications for conservation. Applied Vegetation Science 10: 81-90.

Behling, H., Pillar, V. D. P., and Bauermann, S. G. (2005). Late Quaternary grassland (Campos), gallery forest, fire and climate dynamics, studied by pollen, charcoal and multivariate analysis of the São Francisco de Assis core in western Rio Grande do Sul (southern Brazil). Review of Palaeobotany and Palynology 133: 235-248.

Behling, H., Pillar, V. D. P., Orlóci, L., and Bauermann, S. G. (2004). Late Quaternary Araucaria forest, grassland (Campos), fire and climate dynamics, studied by high-resolution pollen, charcoal and multivariate analysis of the Cambará do Sul core in southern Brazil. Palaeogeography, Palaeoclimatology, Palaeoecology 203: 277-297.

Behling, H., and Pillar, V. D. (2007). Late Quaternary vegetation, biodiversity and fire dynamics on the southern Brazilian highland and their implication for conservation and management of modern Araucaria forest and grassland ecosystems. Philosophical Transactions Royal Society B 362: 243-251.

Bender, B. (1993). Landscape: Politics and Perspectives, Berg, Oxford.

Bender, B. (2002). Time and landscape. Current Anthropology 43: 103-112.

Bernardini, W. (2005a). Hopi Oral Tradition and the Archaeology of Identity, University of Arizona Press, Tucson.

Bernardini, W. (2005b). Reconsidering spatial and temporal aspects of prehistoric cultural identity: A case study from the American Southwest. American Antiquity 70: 31-54.

Bernardini, W. 2011. Migration in fluid social landscapes: Units and processes. In Cabana G., and Clark, J. (eds.), Rethinking Anthropological Perspectives on Migration, University Press of Florida, Gainesville, pp. 31-44.

Bitencourt, A. L., and Kraspenhar, P. M. (2006). Possible prehistoric anthropogenic effect on Araucaria angustifolia (Bert.) O. Kuntze expansion during the Late Holocene. Revista Brasileira de Paleontologia 9: 109-116.

Blanton, R. E., Feinman, G. M., Kowalewski, S. A., and Peregrine, P. N. (1996). A dual-processual theory for the evolution of Mesoamerican civilization. Current Anthropology 37: 1-14.

Boone, J. L. (2000). Status signaling, social power, and lineage survival. In Diehl, M. W. (ed.), Hierarchies in Action: Cui Bono, Center for Archaeological Investigations, Southern Illinois University, Carbondale, pp. 84-110.

Bonomo, M. (2013). Reanálisis de la colección de Samuel Lothrop procedente del Delta del Paraná. Relaciones de la Sociedad Argentina de Antropología 38: 169-198.

Bonomo, M., Aceituno, F. J., Politis, G. G., and Pochettino, M. L. (2011a). Pre-Hispanic horticulture in the Paraná Delta (Argentina): Archaeological and historical evidence. World Archaeology 43: 554-575.

Bonomo, M., Angrizani, R. C., Apolinaire, E., and Noelli, F. S. (2015). A model for the Guaraní expansion in the La Plata Basin and littoral zone of southern Brazil. Quaternary International 356: 54-73.

Bonomo, M., Politis, G., and Gianotti, C. (2011b). Montículos, jerarquía social y horticultura en las sociedades indígenas del Delta del Río Paraná (Argentina). Latin American Antiquity 22: 297-333.

Bonomo, M., and Gianotti, C. (2013). De montículos a paisajes: Procesos de transformación y construcción de paisajes en el sur de la cuenca del Plata. Comechingonia: Revista de Arqueología 17: $129-163$.

Bourdieu, P. (1977). Outline of a Theory of Practice, Cambridge University Press, Cambridge. 
Boyadjian, C. H. (2012). Análise e identificação de microvestígios vegetais de cálculo dentário para a reconstrução de dieta sambaquieira: estudo de caso de Jabuticabeira II, SC, Ph.D. dissertation, Institute of Biological Sciences, University of São Paulo, São Paulo.

Bracco, R. (2006). Montículos de la cuenca de la Laguna Merín: Tiempo, espacio y sociedad. Latin American Antiquity 17: 511-540.

Bracco, R., Cabrera, L., and López Mazz, J. M. (2000a). La prehistoria de las tierras bajas de la cuenca de la Laguna Merín. In Durán, A., and Bracco, R. (eds.), Arqueología de las tierras bajas, Comisión Nacional de Arqueología, Ministerio de Educación y Cultura, Montevideo, pp. 13-38.

Bracco, R., and López Mazz, J. (1989). Prospección arqueológica y foto aérea (Bañado de India Muerta y Bañado de San Miguel) In Primeras jornadas de ciencias antropológicas en Uruguay, Ministerio de Educación y Cultura, Montevideo, pp. 51-56).

Bracco, R., Montaña, J. R., Nadal, O., and Gancio, F. (2000b). Técnicas de construcción y estructuras monticulares. In Durán, A., and Bracco, R. (eds.), Arqueología de las tierras bajas, Comisión Nacional de Arqueología, Ministerio de Educación y Cultura, Montevideo, pp. 287-301.

Bracco, R., del Puerto, L., Inda, H., and Castiñeira, C. (2005). Mid-late Holocene cultural and environmental dynamics in eastern Uruguay. Quaternary International 132: 37-45.

Bracco, R., Puerto, L. d., Inda, H., and García-Rodríguez, F. (2008). Un aporte crítico a partir de "Comentarios sobre montículos de la cuenca de la Laguna Merín: tiempo, espacio y sociedad." Latin American Antiquity 19: 325-335.

Bracco, R., Del Puerto, L., Inda, H., Panario, D., Castiñeira, C., and García-Rodríguez, F. (2011). The relationship between emergence of mound builders in SE Uruguay and climate change inferred from opal phytolith records. Quaternary International 245: 62-73.

Bracco, R., Inda, H., del Puerto, L., Capdepont, I., Panario, D., Castiñeira, C., and García-Rodríguez, F. (2014). A reply to "Relative sea level during the Holocene in Uruguay." Palaeogeography, Palaeoclimatology, Palaeoecology 401: 166-170.

Bradley, R. (1998). The Significance of Monuments: On the Shaping of Human Experience in Neolithic and Bronze Age Europe, Routledge, London.

Brochado, J. P. (1984). An Ecological Model of the Spread of Pottery and Agriculture into Eastern South America, Ph.D. dissertation, Department of Anthropology, University of Illinois, UrbanaChampaign.

Brumfiel, E. M., and Fox, J. W. (eds.) (1994). Factional Competition and Political Development in the New World, Cambridge University Press, Cambridge.

Buarque, A. (2010). As estruturas funerárias das aldeias Tupinambá da região de Araruama, RJ. In Prous, A., and Andrade Lima, T. (eds.), Os ceramistas Tupiguarani, Vol. 3, IPHAN, Belo Horizonte, pp. $149-172$.

Burger, R. (1995). Chavin and the Origins of Andean Civilization, Thames and Hudson, London.

Bush, M., Silman, M., McMichael, C., and Saatchi, S. (2008). Fire, climate change and biodiversity in Amazonia: A Late-Holocene perspective. Philosophical Transactions of the Royal Society B 363: $1795-1802$.

Cabral, M. P., and Saldanha, J. D. (2008). Paisagens arqueológicas na costa norte do Amapá. Revista de Arqueologia SAB 21: 1-14.

Cabrera, L., Bracco, R., Curbelo, C., Femenias, J., López Mazz, J. M., and Martınez, E. (1989). Primeros resultados de las investigaciones arqueologicas del norte del Departamento de Rocha, Republica. Manuscript on file, Facultad de Humanidades y Ciencias, Universidad de la Republica, Montevideo.

Cabrera, L., Durán, A., Femenias, J., and Marozzi, O. (2000). Investigaciones arqueológicas en el sitio C.G.14E01 "Isla Larga," Sierra de San Miguel, Uruguay. In Durán, A., and Bracco, R. (eds.), Arqueología de las tierrasbBajas, Comisión Nacional de Arqueología, Ministerio de Educación y Cultura, Montevideo, pp. 169-194.

Calderón, V. (1964). O Sambaqui de Pedra Oca, Insituto de Ciencias Socias 2, Universidade da Bahia, Salvador.

Calippo, F. R. (2011). Sociedade sambaquieira, comunidades marítimas. Revista de Museu de Arqueologia e Etnologia 24: 82-101.

Campos, G. (2003). Analisis litológico de la matriz sedimentaria de los sitios arqueológicos. Revista de la Escuela de Antropología 8: 211-222.

Canuto, M. A., and Yaeger, J. (2000). The Archaeology of Communities: A New World Perspective, Routledge, London. 
Capdepont, I., del Puerto, L., and Inda, H. (2005). Instrumentos de molienda: evidencias del procesamiento de recursos vegetales en la laguna de Castillos (Rocha, Uruguay). Intersecciones en Antropología 6: 153-166.

Carneiro, R. (1998). What happened at the flashpoint? Conjectures on chiefdom formation at the very moment of its conception. In Redmond, E. (ed.), Chiefdoms and Chieftaincies in the Americas, University Press of Florida, Gainesville, pp. 18-41.

Carr, C., and Case, D. (eds.) (2006). Gathering Hopewell: Ritual and Ritual Interaction, Springer, New York.

Caruso, Jr., F. (1995). Mapa geológico e de recursos minerais do sudeste de Santa Catarina, Departamento Nacional de Produção Mineral, Brasília.

Cashdan, E. A. (1980). Egalitarianism among hunters and gatherers. American Anthropologist 82: $116-120$.

Castiñeira, C., Blasi, A. M., Bonomo, M., Politis, G. G., and Apolinaire, E. (2014). Modificación antrópica del paisaje durante el holoceno tardío: las construcciones monticulares en el delta superior del río Paraná. Revista de la Asociación Geológica Argentina 71: 33-47.

Cerutti, C. (2003). Entidades culturales presentes en la cuenca del Paraná Medio (margen entrerriana). Mundo de Antes 3: 111-135.

Chapman, R. (2003). Archaeologies of Complexity, Routledge, London.

Chmyz, I. (1967). Dados parciais sobre a arqueologia do Vale do Rio Paranapanema. In Publicações Avulsas No. 6, Programa Nacional de Pesquisas Arqueológicas - Resultados Preliminares do Primeiro Ano 1965-1966, Vol. 6, Museu Paraense Emílio Goeldi, Belém, pp. 59-78.

Chmyz, I., and Sauner, Z. C. (1971). Nota prévia sobre as pesquisas arqueológicas no vale do Rio Piquiri. Dédalo 13: 7-36.

Clapperton, C. (1993). A Quaternary Geology and Geomorphology of South America, Elsevier, Amsterdam.

Clark, J. E., and Blake, M. (1994). The power of prestige: Competitive generosity and the emergence of rank societies in lowland Mesoamerica. In Brumfiel, E. M., and Fox, J. R. (eds.), Factional Competition and Political Development in the New World, Cambridge University Press, Cambridge, pp. 17-30.

Clement, C. R., de Cristo-Araújo, M., Coppens D’Eeckenbrugge, G., Alves Pereira, A., and PicançoRodrigues, D. (2010). Origin and domestication of native Amazonian crops. Diversity 2: 72-106.

Collier, J., and Rosaldos, M. (1982). Politics and gender in simple societies. In Ortner, S., and Whitehead, H. (eds.), Sexual Meanings, Cambridge University Press, New York, pp. 137-147.

Colonese, A. C., Collins, M., Lucquin, A., Eustace, M., Hancock, Y., Ponzoni, R., Mora, A., DeBlasis, P., Figuti, L., Wesolowski, V., Plens, C. R., Eggers, S., Farias, D. S., Gledhill, A., and Craig, O. E. (2014). Long-term resilience of Late Holocene coastal subsistence system in southeastern South America. PLoS One 9: e93854.

Copé, S. M. (2006). Les grands constructeurs précoloniaux du sud Brésil: etude de paysages archéologiques a Bom Jesus, Rio Grande do Sul, Brésil, Ph.D. dissertation, Institut d'Art et d'Archéologie, Paris I Panthéon-Sorbonne, Paris.

Copé, S. M. (2007). El uso de la arquitectura como artefacto en el estudio de paisajes arqueológicos del altiplano sur brazileño. Revista de Arquelogía, Universidad de Mar del Plata 2: 15-34.

Copé, S. M., Saldanha, J. D., and Petry Cabral, M. (2002). Em busca de um sistema de assentamento para o Planalto Sul-Rio-Grandense: escavações no sítio RS-AN-03, Bom Jesus, RS. Pesquisas Antropologia 58: 107-120.

Corrêa, A. A. (2014). Pindorama de Mboia e Iakare: Continuidades e mudança na trajetória das populações Tupi, Ph.D. dissertation, Museum of Archaeology and Ethnology, University of São Paulo, São Paulo.

Corteletti, R. (2008). Patrimônio arqueológico de Caxias do Sul, Nova Prova, Porto Alegre.

Corteletti, R. (2012). Projeto arqueológico Alto Canoas - Paraca: um estudo da presença Jê no Planalto Catarinense, Ph.D. dissertation, Museum of Archaeology and Ethnology, University of São Paulo, São Paulo.

Corteletti, R., Dickau, R., DeBlasis, P., and Iriarte, J. (2015). Revisiting the economy and mobility of Southern Proto-Jê (Taquara-Itararé) groups in the southern Brazilian highlands: Starch grain and phytoliths analyses from the Bonin site, Urubici, Brazil. Journal of Archaeological Science 58: 46-61.

Creamer, W., and Haas, J. (1985). Tribe versus chiefdom in lower Central America. American Antiquity 50: 738-754. 
Crépeau, R. (1994). Mythe et rituel chez les indiens Kaingang du Bresil meridional. Religiologiques 10: $143-157$.

Criado Boado, F. (1993). Límites y posibilidades de la arqueología del paisaje. Spal 2: 9-55.

Criado Boado, F., Gianotti, C., and Mañana-Borrazás, P. (2006). Before the barrows: Forms of monumentality and forms of complexity in Iberia and Uruguay. In Šmejda, L. (ed.), Archaeology of Burial Mounds, University of West Bohemia, Plzeň, pp. 38-52.

Crumley, C. (1987). A dialectical critique of hierarchy. In Patterson, T. C., and Gailey, C. W. (eds.), Power Relations and State Formation, American Anthropological Association, Washington, DC, pp. $155-169$.

Cruz, D. G. (2008). Lar, doce lar? Arqueologia Tupi na bacia do Ji-Paraná (RO), Ph.D. dissertation, Museum of Archaeology and Ethnology, University of São Paulo, São Paulo.

DeBlasis, P., Farias, D.S., and Kneip, A. (2014). Velhas tradições e gente nova no pedaço: perspectivas longevas de arquitetura funerária na paisagem do litoral sul catarinense. Revista do Museu de Arqueologia e Etnologia 24: 109-136. São Paulo.

DeBlasis, P., Fish, S. K., Gaspar, M. D., and Fish, P. R. (1998). Some references for the discussion of complexity among the Sambaqui moundbuilders from the southern shores of Brazil. Revista de Arqueologia Americana 15: 75-105.

DeBlasis, P., Kneip, A., Scheel-Ybert, R., Giannini, P., and Gaspar, M. D. (2007). Sambaquis e paisagem: dinâmica natural e arqueologia regional no litoral sul do Brasil. Arqueología Sudamericancal Arqueologia Sul-Americana 3: 29-61.

De Boer, W. R. (1997). Ceremonial centres from the Cayapas (Esmeraldas, Ecuador) to Chillicothe (Ohio, USA). Cambridge Archaeological Journal 7: 225-253.

DeMasi, M. A. (2006). Arqueologia das terras altas do Sul do Brasil: o baixo vale do Rio Canoas, SC. In DeMasi, M. A. (ed.), Xokleng 2860 AC: As terras altas do sul do Brasil, Unisul, Tubarão, pp. 47-75.

DeMasi, M. A. (2009). Centros cerimoniais do planalto meridional: uma análise intra-sítio. Revista de Arqueologia SAB 22: 99-113.

DeMasi, M. A., and Artusi, L. (1985). Fase Itapiranga: sítios da tradição planáltica. Pesquisas: Antropologia 40: 99-121.

De Oliveira, J. E. (2000). O uso tradicional da palmeira Acuri pelos índios Guató e suas implicações para a arqueologia no Pantanal. Clio 14: 281-298.

De Oliveira, J. E. (2004). Arqueologia das sociedades indígenas no Pantanal, Editora Oeste, Campo Grande, Mato Grosso.

De Souza, J. G., and Copé, S. (2010). Novas perspectivas sobre a arquitetura ritual do planalto meridional brasileiro: pesquisas recentes em Pinhal da Serra, RS. Revista de Arquelogia SAB 23: 104-117.

De Souza, J. G., Corteletti, R., Robinson, M., and Iriarte, J. (2016). The genesis of monuments: Resisting outsiders in the contested landscapes of southern Brazil. Journal of Anthropological Archaeology 41: 196-212.

Del Puerto, L., and Inda, H. (2005). Paleoetnobotánica de los constructores de túmulos del Noroeste del Uruguay: Análisis de silicofitolitos de la estructura monticular YALE $27 \mathrm{y}$ su entorno. TAPA, IEGPS-CSIC, Santiago de la Compostela 36: 109-120.

Del Puerto, L. (2015). Interacciones humano ambientales durante el Holoceno Tardío en las tierras bajas del este de Uruguay, Ph.D. dissertation, Department of Anthropology, Universidad de la República, Montevideo.

Denevan, W. M. (2001). Cultivated Landscapes of Native Amazonia and the Andes, Oxford University Press, New York.

Diamond, J., and Bellwood, P. (2003). Farmers and their languages: The first expansions. Science 300: $597-603$.

Dias, J. L. (2005). A tradição taquara e sua ligação com o Índio Kaingang. Documentos 10:126-158.

Dietler, M. (2001). Theorizing the feast: Rituals of consumption, commensal politics, and power in African contexts. In Dietler, M., and Hayden, B. (eds.), Feasts: Archaeological and Ethnographic Perspectives on Food, Politics, and Power, Smithsonian Institution Press, Washington, DC, pp. 240-264.

Dillehay, T. D. (1993). Archaeological trends in the southern cone of South America. Journal of Archaeological Research 1: 235-266.

Dillehay, T. D. (2007). Monuments, Empires, and Resistance: The Araucanian Polity and Ritual Narratives, Cambridge University Press, Cambridge.

Dillehay, T. D. (2011). From Foraging to Farming in the Andes: New Perspectives on Food Production and Social Organization, Cambridge University Press, Cambridge. 
Dillehay, T. (2014). The Teleoscopic Polity: Andean Patriarchy and Materiality, Springer, New York.

Dillehay, T. D. (n.d.). Speculations on the meaning of mound-building cultures in northeast Uruguay and southeast Brazil. Manuscript on file, Department of Anthropology, University of Kentucky, Lexington.

Dos Reis, M. S., Ladio, A., and Peroni, N. (2014). Landscapes with Araucaria in South America: Evidence for a cultural dimension. Ecology and Society 19: 43 (electronic).

Drennan, R. D. (1976). Religion and social evolution in Formative Mesoamerica. In Flannery, K. V. (ed.), The Early Mesoamerican Village, Academic Press, New York, pp. 345-368.

Drennan, R. D. (1991). Pre-hispanic chiefdom trajectories in Mesoamerica, Central America, and northern South America. In Earle, T. K. (ed.), Chiefdoms: Power, Economy, and Ideology, Cambridge University Press, Cambridge, pp. 263-287.

Drennan, R. D. (1995). Chiefdoms in northern South America. Journal of World Prehistory 9: 301-340.

Durán, A. and Bracco, R. (2000). Arqueología de las tierras bajas, Comisión Nacional de Arqueología, Ministerio de Educación y Cultura, Montevideo.

Earle, T. K. (1991). The evolution of chiefdoms. In Earle, T. K. (ed.), Chiefdoms: Power, Economy, and Ideology, Cambridge University Press, Cambridge, pp. 1-15.

Edmond, M. (1999). Ancestral Geographies of the Neolithic: Landscape, Monuments and Memory, Routledge, Oxford.

Ehrenreich, R., Crumley, C., and Levy, J. (eds.) (1995). Heterarchy and the Analysis of Complex Societies. Archeological Papers Vol. 6, American Anthropological Association, Arlington, VA.

Farias, D. S., Neu, M. F., and Rampazzo, S. E. (2015). O padrão de assentamiento e o aproveitamento do ambiente pelos grupos pré-históricos na região da Amurel: Projeto arqueologia na Mata Atlântica AMA. Revista Gestão and Sustentabilidade Ambiental 4: 332-365.

Fausto, C. (2001). Inimigos fiéis: história, guerra e xamanismo na Amazônia, Edusp, São Paulo.

Feinman, G., and Neitzel, J. (1984). Too many types: An overview of sedentary prestate societies in the Americas. Advances in Archaeological Method and Theory 7: 39-102.

Feinman, G. M. (1999). Defining a contemporary landscape approach: Concluding thoughts. Antiquity 73: $650-660$.

Femenías, J., and Sans, M. (2000). Subsistencia, movilidad, y organizacion social en el sitio monticular CH2D01-A (Rocha-Uruguay): Inferencias a partir de las pautas de enterramientos y los restos esqueletarios. In Durán, A., and Bracco, R. (eds.), Arqueología de lastTierras bajas, Comisión Nacional de Arqueología, Ministerio de Educación y Cultura, Montevideo, pp. 383-394.

Fernandes, R. C. (2000). Uma contribução da antropologia política para a análise do faccionalismo Kaingang. In Mota, L. T., Noelli, F., and Tommasino, K. (eds.), Uri e Wãxi: estudos interdisciplinares dos Kaingang, UEL, Londrina, pp. 85-143.

Figuti, L., and Klokler, D. M. (1996). Resultados preliminaries dos vestígios zooarqueológicos do sambaqui Espinheiros II (Joinville, SC). Revista do Museu de Arqueologia e Etnologia 6: 169-188.

Fish, P., Fish, S., DeBlasis, P., and Gaspar, M. D. (2013). Ecological perspectives on persistent places in southern coastal Brazil. In Thompson, V. D., and Waggoner, Jr, J. C. (eds.), The Archaeology and Historical Ecology of Small Scale Societies, University Press of Florida, Gainesville, pp. 120-140.

Fish, S. K., DeBlasis, P., Gaspar, M. D., and Fish, P.R. (2000). Eventos incrementais na construção de sambaquis, litoral sul do estado de Santa Catarina. Revista do Museu de Arqueologia e Etnologia 10: 69-87. São Paulo.

Flanagan, J. G. (1989). Hierarchy in simple" egalitarian" societies. Annual Review of Anthropology 18: 245-266.

Ford, R. (1962). A Quantitative Method for Deriving Cultural Chronology, Vol. 1, Technical Manual, Pan American Union, Washington, DC.

Frenguelli, J., and Aparicio, F. (1923). Los paraderos de la margen derecha del rio Malabrigo (departamento de Reconquista, Prov. de Santa Fe). Anales de la Facultad de Ciencias de la Educacion 1: 7-112.

Fried, M. (1967). The Evolution of Political Society, Random House, New York.

Gaspar, M. D. (1998). Considerations of the sambaquis of the Brazilian coast. Antiquity 72: 592-615.

Gaspar, M. D. (2000). Sambaquis: arqueologia do litoral, Jorge Zahar Editora, Rio de Janeiro.

Gaspar, M., DeBlasis, P., Fish, S., and Fish, P. (2008). Sambaqui (shell mound) societies of coastal Brazil. In Silverman, H., and Isbell, W. (eds.), The Handbook of South American Archaeology, Springer, New York, pp. 319-335.

Gassón, R. A. (2002). Orinoquia: The archaeology of the Orinoco River basin. Journal of World Prehistory 16: 237-311. 
Gessert, S., Iriarte, J., Ríos, R. C. and Behling, H. (2011). Late Holocene vegetation and environmental dynamics of the Araucaria forest region in Misiones Province, NE Argentina. Review of Palaeobotany and Palynology 166: 29-37.

Giannini, P. C. (1993). Sistemas deposicionais no Quaternário costeiro entre Jaguaruna e Imbituba, SC, Ph.D. dissertation, Institute of Earth Sciences, University of São Paulo, São Paulo.

Gianotti, C. (1998). Ritual funerario y prácticas mortuorias en las tierras bajas de Uruguay, Monograph, Facultad de Humanidades y Ciencias de la Educación, Universidad de la República, Montevideo.

Gianotti, C. (2000). Monumentalidad, ceremonialismo y continuidad ritual. In Gianotti, C. (ed.), Paisajes culturales sudamericanos: de las prácticas sociales a las representaciones, TAPA, 19, Laboratorio de Arqueoloxía de Paisaxe, Galicia, pp. 87-102.

Gianotti, C. (2005). Desarrollo metodológico y aplicación de nuevas tecnologías para la gestión integral del patrimonio arqueológico del Uruguay, TAPA, 36, Laboratorio de Arqueoloxía de Paisaxe, Galicia.

Gianotti, C., and Bonomo, M. (2013). De montículos a paisajes: procesos de transformación y construcción de paisajes en el sur de la cuenca del Plata. Comechingonia 17: 129-163.

Gianotti, C., and López Mazz, J. M. (2009). Prácticas funerarias en la localidad arqueológica Rincón de Los Indios. In López Mazz, J. M., and Gascue, A. (eds.), Arqueología prehistórica uruguaya en el siglo XXI, Biblioteca Nacional, Montevideo, pp. 151-196.

Giddens, A. (1979). Central Problems in Social Theory: Action, Structure, and Contradiction in Social Analysis, University of California Press, Berkeley.

Gilman, A. (1991). Trajectories toward social complexity in the later prehistory of the Mediterranean. In Earle, T. (ed.), Chiefdoms: Power, Economy and Ideology, University of Cambridge Press, Cambridge, pp. 146-168.

Hayden, B. (1995). Pathways to power: Principles for creating socioeconomic inequalities. In Price, T. D. and Feinman, G. M. (eds.), Foundations of Social Inequality, Springer, New York, 15-86.

Hayden, B. (2001). Richman, poorman, beggarman, chief: The dynamics of social inequality. In Price, T. D., and Feinman, G. M. (eds.), Archaeology at the Millennium: A Sourcebook, Springer, New York, pp. 231-272.

Heckenberger, M. (2002). Rethinking the Arawakan diaspora: Hierarchy, regionality, and the Amazonian formative. In Hill, J. D., and Santos-Granero, F. (eds.), Comparative Arawakan Histories: Rethinking Language Family and Culture Area in Amazonia, University of Illinois Press, Urbana, pp. 99-122.

Heckenberger, M., and Neves, E. G. (2009). Amazonian archaeology. Annual Review of Anthropology 38: 251-266.

Heckenberger, M. J., Neves, E. G., and Petersen, J. B. (1998). De onde surgem os modelos? As origens e expansões Tupi na Amazônia Central. Revista de Antropologia 41: 69-96.

Heckenberger, M. J., Russell, J. C., Fausto, C., Toney, J. R., Schmidt, M. J., Pereira, E., Franchetto, B., and Kuikuro, A. (2008). Pre-Columbian urbanism, anthropogenic landscapes, and the future of the Amazon. Science 321: 1214-1217.

Helms, M. W. (1994). Chiefdom rivalries, control, and external contacts in lower Central America. In Brumfiel, E. M., and Fox, J. W. (eds.), Factional Competition and Political Development in the New World, Cambridge University Press, Cambridge, pp. 55-60.

Henry, J. (1964). Jungle People: A Kaingáng Tribe of the Highlands of Brazil, Vintage Books, New York.

Hornborg, A. (2005). Ethnogenesis, regional integration, and ecology in prehistoric Amazonia: Toward a system perspective. Current Anthropology 46: 589-620.

Hurt, W. R. (1974). The Interrelationship between the Natural Environment and Four Sambaquis, Coast of Santa Catarina, Brasil, Indiana University Museum, Bloomington.

Iriarte, J. (2003). Mid-Holocene Emergent Complexity and Landscape Transformation: The Social Construction of Early Formative Communities in Uruguay, La Plata Basin, Ph.D. dissertation, Department of Anthropology, University of Kentucky, Lexington.

Iriarte, J. (2006a). Landscape transformation, mounded villages and adopted cultigens: The rise of Early Formative communities in southeastern Uruguay. World Archaeology 38: 644-663.

Iriarte, J. (2006b). Vegetation and climate change since 14,810 C-14 yr BP in southeastern Uruguay and implications for the rise of Early Formative societies. Quaternary Research 65: 20-32.

Iriarte, J. (2007). Emerging food-production systems in the La Plata Basin: The Los Ajos site. In Deham, T., Iriarte, J., and Vrydaghs, L. (eds.), Rethinking Agriculture: Archaeological and Ethnoarchaeological Perspectives, Left Coast Press, Walnut, CA, pp. 257-272. 
Iriarte, J. (2009). Emerging food-producing systems in the La Plata Basin: The Los Ajos site. Rethinking Agriculture: Archaeological and Ethnoarchaeological Perspectives 51: 256-272.

Iriarte, J. (2013). "Down under the marshes": Investigating settlement patterns of the Early Formative mound-building cultures of southeastern Uruguay through historic aerial photography. In Hanson, W. S., and Oltean, I. A. (eds.), Archaeology from Historical Aerial and Satellite Archives, Springer, New York, pp. 243-260.

Iriarte, J., and Alonso, E. A. (2009). Phytolith analysis of selected native plants and modern soils from southeastern Uruguay and its implications for paleoenvironmental and archeological reconstruction. Quaternary International 193: 99-123.

Iriarte, J., and Behling, H. (2007). The expansion of Araucaria forest in the southern Brazilian highlands during the last 4000 years and its implications for the development of the Taquara/Itarare tradition. Environmental Archaeology 12: 115-127.

Iriarte, J., Corteletti, R., De Souza, J. G., and DeBlasis, P. (2016). Landscape dynamics in the La Plata Basin during the mid and late Holocene. Cadernos do LEPAARQ-UFPEL 13: 268-302.

Iriarte, J., Gillam, J. C., and Marozzi, O. (2008a). Monumental burials and memorial feasting: An example from the southern Brazilian highlands. Antiquity 82: 947-961.

Iriarte, J., Holst, I., Marozzi, O., Listotad, C., Alonso, E., Rinderknecht, A., and Montaña, J. (2008b). Comentario sobre" Montículos de la cuenca de la Laguna Merín: tiempo, espacio, y sociedad." Latin American Antiquity 19: 317-324.

Iriarte, J., Holst, I., López Mazz, J. M., and Cabrera, L. (2001). Subtropical wetland adaptations in Uruguay during the mid-Holocene: An archaeobotanical perspective. In Purdy, B. (ed.), Enduring Records: The Environmental and Cultural Heritage of Wetlands, Oxbow Books, Oxford, pp. 61-70.

Iriarte, J., and Marozzi, O. (2009). Análisis del material lítico del sitio de Los Ajos. In Beovide, L., Erchini, C., and Figueiro, G. (eds.), La arqueología como profesión: los primeros 30 años, XI Congreso Nacional de Arqueología Uruguaya, Asociación Uruguaya de Arqueología, Montevideo, pp. 183-201.

Iriarte, J., Holst, I., Marozzi, O., Listopad, C., Alonso, E., Rinderknecht, A., and Montaña, J. (2004). Evidence for cultivar adoption and emerging complexity during the mid-Holocene in the La Plata basin. Nature 432: 614-617.

Iriarte, J., Marozzi, O., and Gillam, J. C. (2010). Monumentos funerarios y festejos rituales: Complejos de recintos y tumulos Taquara/Itarare en ElDorado, Misiones (Argentina). Arqueologia Iberoamericana 6: 25-38.

Iriarte, J., Copé, S., Fradley, M., Lockhart, J. J., and Gillam, J. C. (2013). Sacred landscapes of the southern Brazilian highlands: Understanding Southern Proto-Jê mound and enclosure complexes. Journal of Anthropological Archaeology 32: 74-96.

Jolkesky, M. P. (2010). Reconstrução fonológica elLexical do Proto-Jê Meridional, Ph.D. dissertation, Department of Linguistics, University of Campinas, Campinas.

Kern, A. A., Souza, J. O., and Seffner, F. (1989). Arqueologia de salvamento e a ocupação pré-histórica do vale do rio Pelotas (municípios de Bom Jesus e Vacaria). Veritas 35: 99-127.

Klokler, D. M. (2008). Food for Body and Soul: Mortuary Ritual in Shell Mounds (Laguna - Brazil), Ph.D. dissertation, Department of Anthropology, University of Arizona, Tucson.

Klokler, D., and Gaspar, M.D. (2013). Guia ilustrado do estudo de estruturas funerárias. In Gaspar, M.D., and Mendonça de Souza, S. (eds), Guia ilustrado das abordagens estratégicas em Sambaquis, Ed Habilis, Erechim, pp.102-147.

Kneip, L. M. (1977). Pescadores e coletores pré-históricos do litoral de Cabo Frio, RJ. Coleção Museu Paulista, Série Ensaios 2: 145-169.

Kneip, A. (2004). O povo da lagoa: uso do SIG para modelamento e simulação na area arqueológica do Camacho, Ph.D. dissertation, Museum of Archaeology and Ethnology, University of São Paulo, São Paulo.

Koyama, S., and Thomas, D. (1981). Affluent Foragers: Pacific Coast East and West, National Museum of Ethnology, Osaka.

Lathrap, D. (1970). The Upper Amazon, Praeger, New York.

Ledru, M.-P., Salgado-Labouriau, M. L., and Lorscheitter, M. L. (1998). Vegetation dynamics in southern and central Brazil during the last 10,000 yr BP. Review of Palaeobotany and Palynology 99: $131-142$.

Lee, R. B. (1990). Primitive communism and the origin of social inequality. In Upham, S. (ed.), The Evolution of Political Systems: Socio-Politics in Small Scale Sedentary Societies, Cambridge University Press, Cambridge, pp. 225-246. 
Lessa, A. (2005). Reflexões preliminares sobre paleoepidemiologia da violência em grupos ceramistas litorâneos:(I) Sítio Praia da Tapera-SC. Revista do Museu de Arqueologia e Etnologia 15: 199-207.

Lessa, A., and De Medeiros, J. C. (2001). Reflexões preliminares sobre a questão da violência em populações construtoras de sambaquis: análise dos sítios Cabeçuda (SC) e Arapuan (RJ). Revista do Museu de Arqueologia e Etnologia 11: 77-93.

Lessa, A., and Gaspar, M. (2014). Estratégia de subsistência, complexidade social e violência entre grupos sambaquieiros do litoral brasileiro. In López Mazz, J. M., and Berón, M. (eds.), Indicadores arqueológicos de violencia, guerra y conflicto en Sudamérica, CSIC/UdelaR, Montevideo, pp. $55-80$.

Lima, T. A. (2000). Em busca dos frutos do mar: os pescadores-coletores do litoral centro-sul do Brasil. Revista do Museu de Arqueologia e Etnologia 44: 270-327.

Lima, T. A., and López Mazz, J. (1999). La emergencia de complejidad entre los cazadores recolectores de la costa atlantica meridional sudamericana. Revista de Arqueologia Americana 17/18/19: $129-175$.

Lombardo, U., Szabo, K., Capriles, J. M., May, J.-H., Amelung, W., Hutterer, R., Lehndorff, E., Plotzki, A., and Veit, H. (2013). Early and middle Holocene hunter-gatherer occupations in western Amazonia: The hidden shell middens. PLoS One 8: e72746.

López Mazz, J. M. (1999). Some aspects of the French influence upon Uruguayan and Brazilian archaeology. In Alberti, B., and Politis, G. (eds.), Archaeology in Latin America, Routledge, London, pp. 38-58.

López Mazz, J. M. (2001). Las estructuras tumulares (cerritos) del litoral atlántico uruguayo. Latin American Antiquity 12: 231-255.

López Mazz, J. M., and Bracco, R. (1994). Cazadores-recolectores de la cuenca de la Laguna Merín. Arqueología Contemporánea 5: 51-64.

López Mazz, J. M., Dabezies, J. M., and Capdepont, I. (2014). La gestión de recursos vegetales en las poblaciones prehistóricas de las tierras bajas del sureste del Uruguay: un abordaje multidisciplinar. Latin American Antiquity 25: 256-277.

López Mazz, J. M., and Gianotti, C. (1998). Construcción de espacios ceremoniales públicos entre los pobladores prehistóricos de las tierras bajas de Uruguay: el estudio de la organización espacial en la localidad arqueológica Rincón de los Indios. Revista de Arqueologia 11: 87-105.

Loponte, D., Acosta, A., and Musali, J. (2002). Complexity among hunter-gatherers from the Pampean region, Argentina. In Jangsuk, K., Grier, C., and Uchiyama, J. (eds.), Affluent Foragers and Beyond, Oxbow Books, London, pp. 106-125.

Loponte, D., and Acosta, A. (2013). La construcción de la unidad arqueológica Guarani en el extremo meridional de su distribución geográfica. Cuadernos del Instituto Nacional de Antropología y Pensamiento Latinoamericano 1: 193-235.

Loponte, D., and Acosta, A. (2007). Horticultores amazónicos en el humedal del Paraná Inferior: Los primeros datos isotópicos de la dieta. In Bayón, C., Pupio, A., González, M. I., Flegenheimer, N., and Frére, M. (eds.), Arqueología de las Pampas Vol. I, Sociedad Argentina de Antropología, Buenos Aires, pp. 75-93.

Lothrop, S. K. (1931). Indians of the Paraná Delta, Argentina. Annals of the New York Academy of Sciences 33: 77-232.

Macario, K., Buarque, A., Scheel-Ybert, R., Anjos, R., Gomes, P., Beauclair, M., and Hatté, C. (2009). The long-term Tupiguarani occupation in southeastern Brazil. Radiocarbon 51: 937-946.

Mainfort, R. C., and Sullivan, L. P. (1999). Ancient Earthen Enclosures of the Eastern Woodlands, University Press of Florida, Gainesville.

Maniser, H. H. (1930). Les Kaingang de São Paulo. In Proceedings of the 23rd International Congress of Americanists, Science Press, New York, pp. 760-791.

Martin, L., and Suguio, K. (1989). Excursion route along the Brazilian coast between Santos (state of São Paulo) and Campos (north of state of Rio de Janeiro). In International Symposium on Global Changes in South America during the Quaternary, Associação Brasileira de Estudos do Quaternário, São Paulo, pp. 1-136.

Martin, L., Suguio, K., and Flexor, J. M. (1979). Le quaternaire marin du littoral brésilisen entre Cananéia (SP) et Barra de Guaratiba (RJ). In Proceedings of the 1978 International Symposium on Coastal Evolution in the Quaternary, EdUSP, São Paulo, pp. 296-331.

Martin, L., Dominguez, J. M., and Suguio, K. (1986a). Consequence of relative sea-level changes during the Quaternary on sandy coastal sedimentation: examples from Brazil. In Rabassa, J. (ed.), 
Quaternary of South America and Antarctic Peninsula, A. A. Balkema Publishers, Rotterdam, pp. 119-135.

Martin, L., Suguio, K., and Flexor, J. M. (1986b). Relative sea-level reconstruction during the last 7000 years along the States of Paraná and Santa Catarina coastal plains: Additional information derived from shell-middens. In Rabassa, J. (ed.), Quaternary of South America and Antarctic Peninsula, Vol.4, A. A. Balkema Publishers, Rotterdam, pp. 219-236.

Martínez, S., and Rojas, A. (2013). Relative sea level during the Holocene in Uruguay. Palaeogeography, Palaeoclimatology, Palaeoecology 374: 123-131.

Mayle, F. E., and Iriarte, J. (2014). Integrated palaeoecology and archaeology: A powerful approach for understanding pre-Columbian Amazonia. Journal of Archaeological Science 51: 54-64.

Mazza, B., and Loponte, D. (2012). Las prácticas mortuorias en el humedal del Paraná inferior. Arqueologia Iberoamericana 13: 3-21.

McGuire, R., and Paynter, R. (1991). The archaeology of inequality: Material culture, domination and resistance. In McGuire, R., and Paynter, R. (eds.), The Archaeology of Inequality, Blackwell, Oxford, pp. 1-27.

Meggers, B. J., and Evans, C. (1978). Lowland South America and the Antilles. In Jennings, J. D. (ed.), Ancient Native Americans, Freeman, San Francisco, pp. 543-591.

Meillassoux, C. (1978). Kinship relations and relations of production. In Seddon, D. (ed.), Relations of Production: Marxist Approaches to Economic Anthropology, Frank Cass, London, pp. 289-330.

Mendonça de Souza, S., Wesolowski, V., Lessa, A., and Rodrigues-Carvalho, C. (2013). Guia ilustrado para escavar e interpreter lugares de deposição dos mortos. In Gaspar, M. D., and Mendonça de Souza, S. (eds.) Guia ilustrado das abordagens estratégicas em Sambaquis, Ed Habilis, Erechim, pp. $148-167$.

Menghin, O. F. (1957). El poblamiento prehistorico de misiones. Anales de Arqueología y Etnologia, Mendoza XII: $19-40$.

Métraux, A. (1934). El estado actual de nuestros conocimientos sobre la extensión primitiva de la influencia Guaraní y Arawak en el continente sudamericano. In Actas y Trabajos Científicos del XXV Congreso Internacional de Americanistas, Vol. 1, Universidad Nacional de La Plata, La Plata, pp. 181-190.

Métraux, A. (1946). The Caingang. In Steward, J. H. (ed.), Handbook of South American Indians, Vol. 1, Smithsonian Institution Press, Washington, DC, pp. 445-477.

Migliacio, M. C. (2000). A ocupação pré -colonial do Pantanal de Cáceres, Mato Grosso: uma leitura preliminary, Ph.D. dissertation, Museum of Archaeology and Ethnology, University of São Paulo, São Paulo.

Migliazza, E. (1982). Linguistic prehistory and the refuge model in Amazonia. In Prance, G. T. (ed.), Biological Diversification in the Tropics: Proceedings of the Fifth International Symposium of the Association for Tropical Biology, Columbia University Press, New York, pp. 497-519.

Milheira, R. G. (2008). Território e estratégia de assentamento guarani na planície sudoeste da Laguna dos Patos e Serra do Sudeste - RS. M.A. thesis, University of São Paulo, São Paulo.

Milheira, R. G., and DeBlasis, P. (2014). Tupi-Guarani archaeology in Brazil. In Smith, C. (ed.), Encyclopedia of Global Archaeology, Springer, New York, pp. 7384-7389.

Miller, E. T. (1967). Pesquisas arqueológicas efetuadas no nordeste do Rio Grande do Sul. Publicações Avulsas do Museu Paraense Emílio Goeldi 6: 15-38.

Miller, E. T. (1992). Arqueologia nos empreendimentos hidrelétricos da eletronorte: resultados preliminares, Eletronorte/Ministério de Minas e Energia, Brasília.

Miller, E. T. (2009). A cultura cerâmica do Tronco Tupí no Alto Ji-Paraná, Rondônia, Brasil: algumas reflexões teóricas, hipotéticas e conclusivas. Revista Brasileira de Linguística Antropológica 1: 35-136.

Miller, E. T. (2013). Algumas culturas ceramistas, do noroeste do Pantanal do Guaporé à encosta e altiplano sudoeste do Chapadão dos Parecis: origem, difusão/migração e adaptação - do noroeste da América do sul ao Brasil. Revista Brasileira de Linguística Antropológica 5: 335-383.

Moseley, M. E. (2001). The Incas and Their Ancestors, Thames and Hudson, New York.

Müller, L. M., and Mendonça de Souza, S. (2011). Cremações e sepultamentos: as estruturas anelares do planalto. In Carbonera, M., and Schmitz, P. I. (eds.), Antes do oeste catarinense: arqueologia dos povos indígenas, Argos, Chapecó, pp. 269-305.

Myers, N., Mittermeier, R. A., Mittermeier, C. G., Da Fonseca, G. A., and Kent, J. (2000). Biodiversity hotspots for conservation priorities. Nature 403: 853-858. 
Neiman, F. D. (1997). Conspicuous consumption as wasteful advertising: A Darwinian perspective on spatial patterns in Classic Maya terminal monument dates. In Barton, C., and Clark, G. (eds.), Rediscovering Darwin: Evolutionary Theory and Archaeological Explanation, Archeological Papers No. 7, American Anthropological Association, Washington, DC, pp. 267-290.

Nelson, B. A. (1995). Complexity, hierarchy, and scale: A controlled comparison between Chaco Canyon, New Mexico, and La Quemada, Zacatecas. American Antiquity 60: 597-618.

Neves, E. (2011). Archaeological cultures and past identities in the pre-Colonial central Amazon. In Hornborg, A., and Hill, J.D. (eds.), Ethnicity in Ancient Amazonia: Reconstructing Past Identities from Archaeology, Linguistics, and Ethnohistory, University Press of Colorado, Boulder, pp. 31-56.

Neves, W. A., Bernardo, D. V., Okumura, M., Almeida, T. F., and Strauss, A. M. (2011). Origin and dispersion of the Tupiguarani: What does cranial morphology say? Boletim do Museu Paraense Emílio Goeldi: Ciências Humanas 6: 95-122.

Noelli, F. (1993). Sem Tekohá não há Tekó: em busca de um modelo etnoarqueológico da aldeia e da subsistência guarani e sua aplicação a uma área de domínio no delta do Rio Jacuí - RS. M.A. thesis, Department of History, Pontifícia Universidade Católica do Rio Grande do Sul, Porto Alegre.

Noelli, F. (1998). The Tupi: Explaining origin and expansions in terms of archaeology and of historical linguistics. Antiquity 277: 648-663.

Noelli, F. S. (1999/2000). A ocupação humana na região sul do Brasil: arqueologia, debates e perspectivas. Revista USP 44: 218-269.

Noelli, F. S. (2005). Rethinking stereotypes and the history of research on Jê populations in South Brazil: An interdisciplinary point of view. In Funari, P., Zarankin, A., and Stovel, E. (eds.), Global Archaeological Theory: Contextual Voices and Contemporary Thoughts, Springer, New York, pp. 167-190.

Nordenskiöld, E. (1930). ArsaAmericana I: ĺarchélogie du Bassin de ĺAmazone, Les Editions G. Van Oest, Paris.

Okumura, M. M., and Eggers, S. (2005). The people of Jabuticabeira II: Reconstruction of the way of life in a Brazilian shellmound. Homo 55: 263-281.

Olsen, K. M., and Schaal, B. A. (1999). Evidence on the origin of cassava: Phylogeography of Manihot esculenta. Proceedings of the National Academy of USA 6: 5586-5591.

O'Shea, J. M., and Milner, C. M. (2002). Material indicators of territory, identity, and interaction in a prehistoric tribal system. In Parkinson, W. A. (2002), The Archaeology of Tribal Societies, University of Michigan Press, Ann Arbor, pp. 200-226.

Parellada, C. I. (2005). Estudo arqueológico no Vale do Rio Ribeira: area do Gasoduto Bolívia-Brasil, Trecho X, Paraná, Ph.D. dissertation, Department of History, University of São Paulo, São Paulo.

Parkinson, A. W. (ed.) (2002). The Archaeology of Tribal Societies, International Monographs in Prehistory, Ann Arbor, MI.

Pauketat, T. R. (ed.) (2001). The Archaeology of Traditions: Agency and History Before and After Columbus, University Press of Florida, Gainesville.

Pauketat, T. R. (2007). Chiefdoms and Other Archaeological Delusions, AltaMira Press, Lanham, MD.

Pauketat, T. R. (2010). Practice and history in archaeology: An emerging paradigm. In Preucel, R. W., and Mrozowski, S. A. (eds.), Contemporary Archaeology in Theory: The New Pragmatism, WileyBlackwell, Oxford, pp. 137-155.

Pauketat, T. R., and Loren, D. D. (2005). Alternative histories and North American archaeology. In Pauketat, T. R., and Loren, D. D. (eds.), North American Archaeology, Blackwell, Oxford, pp. 1-29.

Paula, J. M. (1924). Memória sobre os Botocudos de Paraná e Santa Catarina organizada pelo serviço de proteção dos selvícolas. In Anais do 200 Congresso Internacional de Americanistas, Vol. 1, Rio de Janeiro, pp. 117-137.

Peebles, C. S., and Kus, S. M. (1977). Some archaeological correlates of ranked societies. American Antiquity 42: 421-448.

Peixoto, J. L. S., Bezerra, A., Mozeto, A. A., and Hilbert, K. (2001). Evolução das grandes lagoas e a ocupação humana no Pantanal Mato-Grossense durante o Holoceno. In Boletim de Resumos do VIII Congreso da ABEQUA, Mariluz, pp. 438-439.

Pestana, M. (2007). A tradição tupiguarani na Porção central da planície costeira do Rio Grande do Sul, Brasil. M.A. thesis, Centro de Ciências Humanas, Universidade do Vale do Rio dos Sinos, São Leopoldo.

Pintos, S. (2000a). Cazadores recolectores complejos: monumentalidad en tierra en la cuenca de la Laguna de Castillos. In Gianotti, C. (ed.), Paisajes culturales sudamericanos: de las practicas 
sociales a las representaciones, Universidad Santiago de la Compostela, Santiago de Compostela, pp. $75-82$.

Pintos, S. (2000b). Economia "húmeda" del este del Uruguay: el manejo de recursos faunísticos. In Durán, A., and Bracco, R. (eds.), Arqueología de las tierras bajas, Comisión Nacional de Arqueología, Ministerio de Educación y Cultura, Montevideo, pp. 249-266.

Pintos, S., and Bracco, R. (1999). Modalidades de enterramiento y huellas de origen antrópico en especimenes oseos humanos: tierras bajas del este del Uruguay (R.O.U.). In López Mazz, J., and Sans, M. (eds.), Arqueología y bioantropología de las tierras bajas, Universidad de la Republica, Montevideo, pp. 81-106.

Plog, F. T. (1974). The Study of Prehistoric Change, Academic Press, New York.

Pohl, M. D., Pope, K. O., Jones, J. G., Jacob, J. S., Piperno, D. R., deFrance, S. D., Lentz, D., Gifford, J. A., Danforth, M. E., and Josserand, J. K. (1996). Early agriculture in the Maya Lowlands. Latin American Antiquity 7: 355-372.

Politis, G. G. (2003). The theoretical landscape and the methodological development of archaeology in Latin America. American Antiquity 14: 245-272.

Politis, G., and Bonomo, M. (2012). La entidad arqueológica Goya-Malabrigo (ríos Paraná y Uruguay) y su filiación Arawak. Revista de Arqueologia SAB 25: 10-46.

Politis, G., and Bonomo, M. (2015). Una revisión del Túmulo de Campaña. Relaciones de la Sociedad Argentina de Antropología 40: 149-181.

Politis, G., Bonomo, M., Castiñeira, C. and Blasi, A. (2011). Archaeology of the upper delta of the Paraná River (Argentina): Mound construction and anthropic landscapes in the Los Tres Cerros locality. Quaternary International 245: 74-88.

Price, T. D., and Brown, J. (1985). Prehistoric Hunter-Gatherers: The Emergence of Cultural Complexity, Academic Press, San Diego.

Price, T. D., and Feinman, G. M. (1995). Foundations of Social Inequality, Plenum Press, New York.

Price, T. D., and Gebauer, A. B. (1995). Last Farmers, First Hunters: New Perspectives on the Prehistoric Transition to Agriculture, School of American Research Press, Santa Fe, NM.

Prous, A. (1977). Les sculptures zoomorphes du sud Brésilien et de l'Uruguay, Éditions de l'École des Hautes Études en Sciences Sociales, Paris.

Prous, A. (1992). Arqueologia brasileira, Editora da UNB, Brasilia.

Prous, A. (2005). A pintura em cerâmica tupiguarani. Ciência Hoje 36: 22-28.

Prous, A. (2010). A pintura na cerâmica tupiguarani. In Prous, A., and Lima, T. A. (eds.), Os ceramistas tupiguarani,Vol II, Elementos Decorativos, Superintendência do Iphan em Minas Gerais, Belo Horizonte, pp. 105-190.

Ramos, M. (2014). Pescando, capturando ou coletando? Interpretação zooestratigráfica de um sambaqui com terra preta na Baía de Paranaguá, Paraná. M.A. thesis. Departamento de Antropologia, Universidade Federal do Paraná. Curitiba.

Redmond, E. (1994). Tribal and Chiefly Warfare in South America, University of Michigan Press, Ann Arbor.

Redmond, E. (1998). Chiefdoms and Chieftaincy in the Americas, University Press of Florida, Gainesville.

Redmond, E., and Spencer, C. (2007). Archaeological Survey in the High Llanos and Andean Piedmont of Barinas Venezuela, Anthropological Papers No. 86, American Museum of Natural History, New York.

Reis, M. J. (2007). A problemática arqueológica das estruturas subterrâneas no Planalto Catarinense, Editora Habilis, Erechim.

Renfrew, C. (1974). Beyond a subsistence economy: The evolution of social organization in prehistoric Europe. Bulletin of the American Schools of Oriental Research: Supplementary Studies 20: 69-95.

Ribeiro, P. A. (1999/2000). A tradição taquara e as casas subterrâneas no sul do Brasil. Revista de Arqueologia Americana 17/18/19: 9-49.

Ribeiro, P. A. (1991). Arqueologia do Vale do Rio Pardo, Rio Grande do Sul, Brasil, Ph.D. dissertation, Department of History, Pontifícia Universidade Católica do Rio Grande do Sul, Porto Alegre.

Riris, P. (2015). Exploring the Spatial Structure of Pre-Columbian Cultural Landscapes in the Alto Paraná (Misiones Province, Argentina), Ph.D. dissertation, Department of Archaeology, University of Southampton, Southampton.

Riris, P., and Corteletti, R. (2015). A new record of pre-Columbian engravings in Urubici (SC), Brazil using polynomial texture mapping. Internet Archaeology 38. http://intarch.ac.uk/journal/issue38/ riris_toc.html 
Rodrigues, A. D. (1964). A classificação do tronco lingüístico Tupi. Revista de Antropologia 12: 99-104.

Rodrigues, A. D. (1984). Relações internas na família lingüística Tupí-Guaraní. Revista de Antropologia 27/28: 33-53.

Rodríguez, J. (1992). Arqueología del sudeste de Sudamérica. In Meggers, B. J. (ed.), Prehistoria sudamericana: nuevas perspectivas, Taraxum, Washington, DC, pp. 177-209.

Rogge, J. H. (2000). A tradição Pantanal: uma nova tradição cerâmica nas Terras Baixas Sul Americanas. In Durán, A., and Bracco, R. (eds.), Arqueología de las tierras bajas, Ministerio de Educación y Cultura, Comisión Nacional de Arqueología, Montevideo, pp. 195-206.

Rogge, J. H. (2004). Fenômenos de fronteira: um estudo das situações de contato entre os portadores das tradições cerâmicas pré-históricas no Rio Grande do Sul, Ph.D. dissertation, Department of History, Universidade do Vale do Sinos, São Leopoldo.

Rogge, J. H. (2005). Fenômenos de fronteira: um estudo das situações de contato entre os portadores das tradições cerâmicas pré-históricas no Rio Grande do Sul. Pesquisas Antropologia 62: 1-119.

Rogge, J. H., and Schmitz, P. I. (2010). Projeto Arroio do Sal: a ocupação indígena pré-Histórica no litoral norte do RS. Pesquisas, Antropologia 68: 167-225.

Rohr, J. A. (1971). Os sítios arqueológicos do planalto catarinense. Pesquisas, Antropologia 24: 1-56.

Rohr, J. A. (1984). Sítios arqueológicos de Santa Catarina. Anais do Museu de Antropologia 17: 77-168.

Roosevelt, A.C. (1992). Arqueologia amazônica. In Carneiro da Cunha, M. (ed.), História dos Índios no Brasil, Companhia das Letras, São Paulo, pp. 53-86.

Roosevelt, A. C. (1999). The development of prehistoric complex societies: Amazonia, a tropical forest. In Bacus, E. A., and Lucero, L. J. (eds.), Complex Polities in the Ancient Tropical World, Archeological Papers Vol. 9, American Anthropological Association, Arlington, VA, pp. 13-33.

Saitta, D. J. (1997). Power, labor, and the dynamics of change in Chacoan political economy. American Antiquity 62: 7-26.

Saldanha, J.D. M. (2005). Paisagem, lugares e cultura material: uma arqueologia espacial nas terras altas do sul do Brasil. Master's thesis, Department of History, Pontifícia Universidade Católica do Rio Grande do Sul, Porto Alegre.

Saldanha, J. D. M. (2008). Paisagems e sepultamentos nas terras altas do sul do Brasil. Revista de Arqueologia $S A B$ 21: 85-95.

Sánchez, J. O., Colobig, M. M., Zucol, A. F., Politis, G. G., Bonomo, M., and Castiñeira, C. (2013). Primeros resultados sobre el uso prehispánico de los vegetales en el sitio arqueológico Los Tres Cerros 1 (Victoria, Entre Ríos, Argentina): análisis del registro biosilíceo. Darwiniana, Nueva Serie 1: 201-219.

Sandweiss, D. H., Maasch, K. A., and Anderson, D. G. (1999). Transitions in the mid-Holocene. Science 283: 499-500.

Santos, E. J. Silva, A. L., Ewerton, P. D., Takeshita, L. Y., and Maia, M. H (2015). Origins and demographic dynamics of Tupí expansion: A genetic tale. Boletim do Museu Paraense Emílio Goeldi: Ciências Humanas 10: 217-228.

Santos, K., Steiner, N., Ducroquet, J., Guerra, M., and Nodari, R. (2005). Domesticação da goiabeiraserrana (Acca sellowiana) no sul do Brasil. Agrociencia 9: 29-33.

Santos-Granero, F. (1998). Writing history into the landscape: Space, myth, and ritual in contemporary Amazonia. American Ethnologist 25: 128-148.

Santos-Granero, F. (2004). Arawakan sacred landscapes, emplaced myths, place rituals, and the production of locality in Western Amazonia. In Halbmayer, E., and Mader, E. (eds.), Kultur, Raum, Landschaft, Brandes and Apsel Verlag, Frankfort, pp. 93-122.

Sassaman, K. (2005). Poverty Point as structure, event, process. Journal of Archaeological Method and Theory 12: 335-364.

Sassaman, K. (2010). Structure and practice in the Archaic Southeast. In Preucel R. W., and Mrozowski, S. A. (eds.), Contemporary Archaeology in Theory: The New Pragmatism, Wiley-Blackwell, Oxford, pp. 170-190.

Saunders, J. W., Mandel, R. D., Saucier, R. T., Allen, E. T., Hallmark, C., Johnson, J. K., Allen, C. M., Stringer, G. L., Frink, D. S., Feathers, J. K., Williams, S., Gremillion, K. J., Vidrine, M. F., and Jones, R. (1997). A mound complex in Louisiana at 5400-5000 years before the present. Science 277: $1796-1799$.

Scabuzzo, C., Raap, A. R., Bonomo, M., and Politis, G. G. (2015). Bioarchaeological study of the Los Tres Cerros site 1 (Upper Delta of the Paraná River, Entre Ríos, Argentina). Boletim do Museu Paraense Emílio Goeldi. Ciências Humanas 10: 509-536. 
Schaan, D. P. (2012). Sacred Geographies of Ancient Amazonia: Historical Ecology of Social Complexity, Left Coast Press, Walnut Creek, CA.

Scheel-Ybert, R. (2001). Man and vegetation in southeastern Brazil during the late Holocene. Journal of Archaeological Science 28: 471-480.

Scheel-Ybert, R. (2013). Preliminary data on nonwood plant remains at Sambaquis from the southern and southeastern Brazilian coast: Considerations on diet, ritual, and site particularities. Cuadernos del Instituto Nacional de Antropología y Pensamiento Latinoamericano-Series Especiales 1: 60-72.

Scheel-Ybert, R., Beauclair, M., and Buarque, A. (2014). The forest people: Landscape and firewood use in the Araruama region, southeastern Brazil, during the late Holocene. Vegetation History and Archaeobotany 23: 97-111.

Scheel-Ybert, R., Macario, K., Buarque, A., Anjos, R. M., and Beauclair, M. (2008). A new age to an old site: The earliest Tupiguarani settlement in Rio de Janeiro State? Anais da Academia Brasileira de Ciências 80: 763-770.

Schmitz, P. I. (1991). Migrantes da Amazônia: a tradição tupiguarani. In Kern, A. (ed.), Arqueologia prehistorica do Rio Grande do Sul, Mercado Aberto, Porto Alegre, pp. 295-330.

Schmitz, P. I. (1999/2000). Arqueologia do planalto sul-brasilero. Revista de Arqueologia Americana 17/ 18/19: 51-74.

Schmitz, P. I., Ribeiro, P. A. M., Naue, G., and Becker, I. B. (1970). Prospecções arqueológicas no vale do Camaquã, RS. In Estudos de Pré-História Geral e Brasileira, Universidade de São Paulo, São Paulo, pp. 508-524.

Schmitz, P. I., Becker, Í. I. B., La Salvia, F., Lazzarotto, D., and Ribeiro, P. a. M. (1988). Pesquisas sobre a tradição Taquara no nordeste do Rio Grande do Sul. Documentos 2: 5-74.

Schmitz, P. I., Naue, G., and Becker, I. (1991). Os aterros dos campos do sul: a tradição Vieiria. In Kern, A. (ed.), Arqueologia pré-histórica do Rio Grande do Sul, Mercado Aberto, Porto Alegre, pp. 221-251.

Schmitz, P. I., Rogge, J. H., Osorio Rosa, A. and Beber, M. V. (1998). Aterros indígenas no Pantanal do Mato Grosso do Sul. Pesquisas, Antropologia 54: 1-271.

Schmitz, P. I., Rogge, J. H., Rosa, A., Beber, M. V., Mauhs, J., and Arnt, F. V. (2002). O Projeto Vacaria: casas subterrâneas no planalto Rio-Grandense. Pesquisas, Antropologia 58: 11-105.

Schmitz, P. I., Rogge, J. H., Osorio Rosa, A., Beber, M. V., and Valer de Freitas, E. A. (2009). Aterros da tradição pantanal nas fazendas sagrado coração de Jesus e Bodoquena, Corumbá, MS. Pesquisas, Antropologia 67: 321-374.

Schmitz, P. I., Arnt, F. V., Beber, M. V., Rosa, A., and Farias, D. S. (2010). Casas subterrâneas no planalto de Santa Catarina: São José do Cerrito. Pesquisas, Antropologia 68: 7-78.

Schmitz, P. I., Rogge, J. H., Novasco, R. V., Mergen, N. M., and Ferraso, S. (2013a). Boa Parada: um lugar de casas subterrâneas, aterros-plataforma e danceiro. Pesquisas: Antropologia 70: 133-195.

Schmitz, P. I., Rogge, J. H., Novasco, R. V., Mergen, N. M., and Ferraso, S. (2013b). Rincão dos Albinos: um grande sítio Jê meridional. Pesquisas: Antropologia 70: 65-131.

Schneider, F. (2014). Interpretação do espaço auarani: um estudo de saso no sul da bacia hidrográfica do Rio Forqueta, Rio Grande do Sul, Brasil. M.A. thesis, Ambiente e Desenvolvimento, Centro Universitário Univates, Lajeado.

Schneider, F., Corteletti, R., Machado, N. T. G., and Stülp, S. (in press). Arqueobotânica Guarani: a presença de grãos de amido, fitólitos e endocarpos carbonizados no sítio RS-T-114, Bacia do Rio Forqueta, Rio Grande do Sul, Brasil. In XIX Congreso Nacional de Arqueología Argentina, Facultad de Ciencias Naturales e Instituto Miguel Lillo de la Universidad Nacional de Tucumán, San Miguel de Tucumán.

Schwarz, F. A., and Scott Raymond, J. (1996). Formative settlement patterns in the Valdivia Valley, SW coastal Ecuador. Journal of Field Archaeology 23: 205-224.

Service, E. R. 1962. Primitive Social Organization: An Evolutionary Perspective, Random House, New York.

Shady Solis, R., Haas, J., and Creamer, W. (2001). Dating Caral, a preceramic site in the Supe Valley on the central coast of Peru. Science 292: 723-726.

Shepard, G., Jr., and Ramirez, H. (2011). "Made in Brazil": Human dispersal of the Brazil nut (Bertholletia excelsa, Lecythidaceae) in ancient Amazonia. Economic Botany 65: 44-65.

Siegel, P. E. (1999). Contested places and places of contest: The evolution of social power and ceremonial space in prehistoric Puerto Rico. Latin American Antiquity 10: 209-238. 
Siemens, A. H. (1999). Wetlands as resource concentrations in southeastern Ecuador. In Nuñez, L., and Blake, M. (eds.), Pacific Latin America in Prehistory: The Evolution of Archaic and Formative Cultures, Washington State University Press, Pullman, pp. 137-147.

Silva, B. (2001). Etnoarqueologia dos grafismos Kaingang, Ph.D. dissertation, Department of Anthropology, University of São Paulo, São Paulo.

Silva, S. B., Schmitz, P. I., Rogge, J. H., DeMasi, M. A., and Jacobus, A. L. (1990). O sítio arqueológico da Praia da Tapera: um assentamento itararé e tupiguarani. Pesquisas, Antropologia 45: 1-210.

Simões, M. F., and Correa, C. G. (1971). Pesquisas arqueológicas na região do Salgado (Pará): a fase Areão do litoral de Mariparim. Boletim do Museu Paraense Emílio Goeldi Ciências Humanas 48: $1-30$.

Smith, A. T. (2003). The Political Landscape: Constellations of Authority in Early Complex Polities, University of California Press, Berkeley.

Spencer, C. S. (1994). Factional ascendance, dimensions of leadership, and the development of centralized authority. In Brumfiel, E. M. (ed.), Factional Competition and Political Development in the New World, Cambridge University Press, Cambridge, pp. 55-60.

Steward, J. H. (1946). Handbook of South American Indians, Vol. 1, Smithsonian Institution Press, Washington, DC.

Steward, J. H., and Faron, L. C. (1959). Native Peoples of South America, McGraw-Hill, New York.

Storto, L. R., and Moore, D. (2001). As línguas indígenas e a pré-história. In S. Pena (ed.), Homo brasilis: aspectos genéticos, linguísticos, históricos e sócio-antropológicos da formação do povo brasileiro, Fundação de Pesquisas Científicas, Ribeirão Preto.

Suárez Villagran, X. S., and Gianotti, C. (2013). Earthen mound formation in the Uruguayan lowlands (South America): Micromorphological analyses of the Pago Lindo archaeological complex. Journal of Archaeological Science 40: 1093-1107.

Suárez Villagran, X. S., Klokler, D. M., Barbosa, P. N., Oliveira, M. D., and Blasis, P. (2010). Stratigraphic reading: Funerary architecture and deposition of waste in Sambaqui Jaboticaba II. Latin American Antiquity 21: 195-216.

Suguio, K., Martin, L., Bittencourt, A., Dominguez, J., Flexor, J. M., and Azevedo, A. (1985). Flutuações do nível relative do mar durante o quaternário superior ao longo do litoral brasileiro e suas implicações na sedimentação costeira. Revista Brasileira de Geociências 15: 273-286.

Teta, P., Loponte, D., A, and Acosta, A. (2004). Sigmodontinos (Mammalia, Rodentia) del Holoceno Tardio del nordeste de la provincia de Buenos Aires (Argentina) Mastozoologia Neotropical 11: 69-80.

Thomas, J. (1999). Understanding the Neolithic, Routledge, Oxford.

Thompson, T. J., and Ulguim, P. (in press). Burned human remains. In Blau, S., and Ubelaker, D. (eds.), Handbook of Forensic Anthropology and Archaeology, Left Coast Press, Walnut Creek, CA.

Thompson, V. D., and Worth, J. E. (2011). Dwellers by the sea: Native American adaptations along the southern coasts of eastern North America. Journal of Archaeological Research 19: 51-101.

Tilley, C. (1995). A Phenomenology of Landscapes: Places, Paths and Monuments, Berg, Oxford.

Torres, L. M. (1911). Los primitivos habitantes del delta del Paraná, Coni Hermanos, Buenos Aires.

Torres, L. M. (1934). Relaciones arqueológicas de los pueblos del amazonas con los del Río de la Plata. In Actas y Trabajos Cientíicos de XXV Congreso Internacional de Americanistas, Vol. II, Buenos Aires, pp. 191-193.

Ulguim, P. F. (2015). Analysing cremated human remains from the southern Brazilian highlands: Interpreting archaeological evidence of funerary practice at mound and enclosure complexes in the Pelotas River Valley. In Thompson, T. (ed.), The Archaeology of Cremation: Burned Human Remains in Funerary Studies, Oxbow Books, Oxford, pp. 173-212.

Upham, S. (1987). A theoretical consideration of middle range societies. In Drennan, R. D. and Uribe, C. A. (eds.), Chiefdoms in the Americas, University Press of America, Lanham, MD, pp. 345-367.

Upham, S. (1990). The Evolution of Political Systems: Sociopolitics in Small-Scale Sedentary Societies, Cambridge University Press, Cambridge.

Urban, G. (1992). A história da cultura brasileira segundo as línguas nativas. In Carneiro da Cunha, M. (ed.), História dos Indios no Brasil, Companhia da Letras, São Paulo, pp. 87-102.

Veiga, J. (2006). Aspectos fundamentais da cultura Kaingang, Editora Curt Nimuendajú, Campinas.

Vincent García, J. M. (1991). El Neolítico: transformaciones sociales y económicas. Boletín de Antropología Americana 24: 31-61.

Viveiros de Castro, E. B. (1992). From the Enemy's Point of View: Humanity and Divinity in an Amazonian Society, University of Chicago Press, Chicago. 
Walker, R. S., Wichmann, S., Mailund, T., and Atkisson, C. J. (2012). Cultural phylogenetics of the Tupi language family in lowland South America. PLoS One 7: e35025.

Wiessner, P. (2002). The vines of complexity: Egalitarian structures and the institutionalization of inequality among the Enga. Current Anthropology 43: 233-269.

Whitney, B. S., Dickau, R., Mayle, F. E., Soto, J. D., and Iriarte, J. (2013). Pre-Columbian landscape impact and agriculture in the Monumental Mound region of the Llanos de Moxos, lowland Bolivia. Quaternary Research 80: 207-217.

Willey, G. R. (1971). An Introduction to American Archaeology, Vol 2: South America, Prentice Hall, Upper Saddle River, NJ.

Whitney, B. S., Mayle, F. E., Punyasena, S. W., Fitzpatrick, K. A., Burn, M. J., Guillen, R., Chavez, E., Mann, D., Pennington, R. T., and Metcalfe, S. E. (2011). A 45kyr palaeoclimate record from the lowland interior of tropical South America. Palaeogeography, Palaeoclimatology, Palaeoecology 307: $177-192$.

Yoffee, N. (1993). Too many chiefs? (or, safe texts for the'90 s). In Yoffee, N., and Sherrat, A. (eds.), Archaeological Theory: Who Sets the Agenda? Cambridge University Press, Cambridge, pp. 60-78.

\section{Bibliography of Recent Literature}

Alho, C. J. (2005). The Pantanal. In Fraser, L. H., and Keddy, P. A. (eds.), The World's Largest Wetlands: Ecology and Conservation, Cambridge University Press, Cambridge, pp. 203-271.

Bracco, R., and Ures, C. (1999). Ritmos y dinámica constructiva de las estructuras monticulares: sector sur de la cuenca de la Laguna Merín-Uruguay. In López Mazz, J., and Sans, M. (eds.), Arqueología y bioantropología de las tierras bajas, Universidad de la República, Montevideo, pp. 13-33.

Cabrera, L. (2000). Los niveles de desarrollo socio-cultural alcanzados por los grupos Cerritos del este uruguayo. In Durán, A., and Bracco, R. (eds.), Arqueología de las tierrasbBajas, Comisión Nacional de Arqueología, Ministerio de Educación y Cultura, Montevideo, pp. 169-181.

De Oliveira, J. E. (2007). Os primeiros passos em direção a uma arqueologia pantaneira: de Max Schmidt e Branka Susnik a outras interpretações sobre os povos indígenas nas terras baixas do Pantanal. Revista de Arqueologia SAB 20: 83-115.

Gaspar, M. D., and Mendonça de Souza, S. (2013). Guia ilustrado das abordagens estratégicas em Sambaquis, Ed Habilis, Erechim.

Gianotti, C. (2004). La prospección como estrategia metodológica para el estudio del paisaje monumental en las tierras bajas uruguayas. Arqueología Espacial SAET 24-25: 259-282.

Hamilton, S. (2002). Human impacts on hydrology in the Pantanal wetland of South America. Water Science and Technology 45: 35-44.

Krepper, C., and Garcí, N. (2004). Spatial and temporal structures of trends and interannual variability of precipitation over the La Plata Basin. Quaternary International 114: 11-21.

López Mazz, J. M., and Sans, M. (1999). Arqueología y bioantropología de las tierras bajas, Universidad de la República, Montevideo.

Milheira, R. G. (2010). Arqueologia guarani no litoral sul-catarinense: história e território, Ph.D. dissertation, Museum of Archaeology and Ethnology, University of São Paulo, São Paulo.

Noelli, F. S. (2004). La distribución geográfica de las evidencias arqueológicas Guaraní. Revista de Indias 64: 17-34.

Peixoto, J. L. S. (1998). Populações indígenas de tradição Tupiguarani no Pantanal Sul-Mato-Grossense. Revista do Museu de Arqueologia e Etnologia 8: 71-86.

Rebellato, L., and Woods, W. I. (2012). A review of the Tupi expansion in the Amazon. In Crawford, M. H., and Campbell, B. C. (eds.) Causes and Consequences of Human Migration: An Evolutionary Perspective, Cambridge University Press, Cambridge, pp. 436-448.

Rodrigues, A. D., and Cabral, A. S. (2012). Tupían. In Campbell, L., and Grondona, V. (eds.), The Indigenous Languages of South America, Mouton de Gruyter, Berlin, pp. 495-574. 